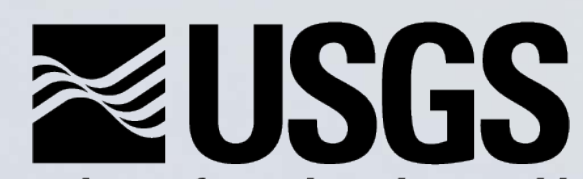

science for a changing world

The Influence of Local- and Landscape-Level Factors on Wetland Breeding Birds in the Prairie Pothole Region of North and South Dakota

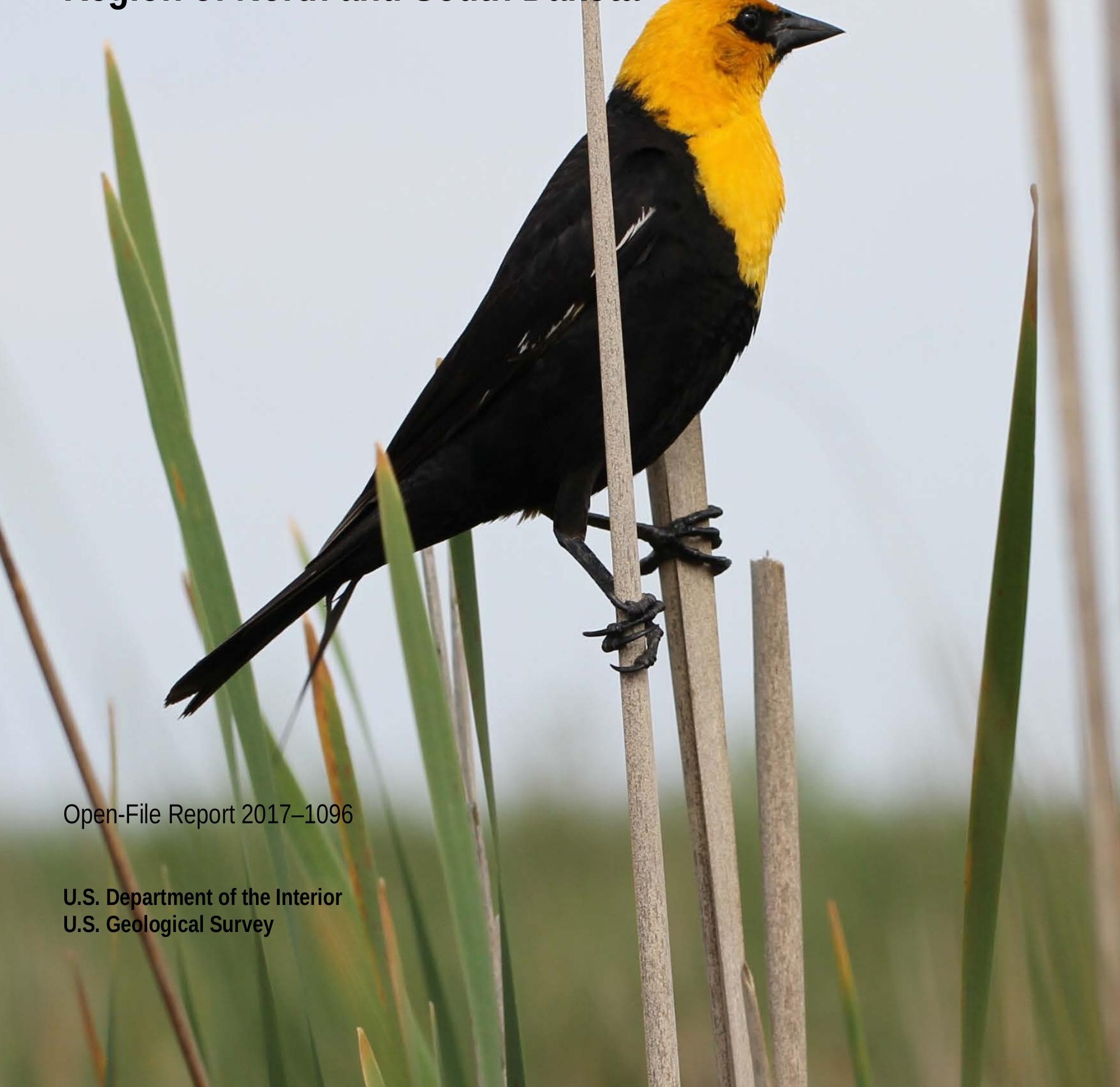


Cover. An adult male Yellow-headed Blackbird (Xanthocephalus xanthocephalus) perching on emergent vegetation (cattails) in a natural, semipermanent wetland on privately owned land in Day County, South Dakota. Photograph by Lawrence D. Igl (U.S. Geological Survey). 


\section{U.S. Department of the Interior \\ RYAN K. ZINKE, Secretary}

U.S. Geological Survey
William H. Werkheiser, Acting Director

U.S. Geological Survey, Reston, Virginia: 2017

For more information on the USGS - the Federal source for science about the Earth, its natural and living resources, natural hazards, and the environment-visit https://www.usgs.gov/ or call 1-888-ASK-USGS (1-888-275-8747).

For an overview of USGS information products, including maps, imagery, and publications, visit https://store.usgs.gov/.

Any use of trade, firm, or product names is for descriptive purposes only and does not imply endorsement by the U.S. Government.

Although this information product, for the most part, is in the public domain, it also may contain copyrighted materials as noted in the text. Permission to reproduce copyrighted items must be secured from the copyright owner.

Suggested citation:

Igl, L.D., Shaffer, J.A., Johnson, D.H., and Buhl, D.A., 2017, The influence of local- and landscape-level factors on wetland breeding birds in the Prairie Pothole Region of North and South Dakota: U.S. Geological Survey Open-File Report 2017-1096, 65 p., https://doi.org/10.3133/ofr20171096. 


\section{Acknowledgments}

Funding for this study was provided by the U.S. Geological Survey and U.S. Fish and Wildlife Service (USFWS). We thank the private landowners and operators for permission to access their property, and the USFWS for permission to conduct bird surveys on USFWS-owned lands and for logistical support throughout the study. We also thank the North Dakota Natural Resources Trust (formerly North Dakota Wetlands Trust) and Arnold D. Kruse for permission to access wetlands on property owned by the Trust in Dickey County, North Dakota. Michael E. Estey and Neal D. Niemuth of the USFWS's Habitat and Populations Evaluation Team provided technical support to summarize the landscape-level variables.

This study was initiated by research staff of the U.S. Geological Survey (USGS) Northern Prairie Wildlife Research Center's Grasslands Ecosystem Initiative, under the leadership of Douglas H. Johnson. The mission of the Grasslands Ecosystem Initiative was to work with others to assess the biotic resources of the Great Plains, to facilitate information sharing among agencies, organizations, and individuals, and to synthesize that information. Field assistance was provided by Jennifer W. Marlow, Melody R. Miller (crew leader), Felicia Y. Sargeant, Jerry W. Toll, and Michael B. Whitt (crew leader) (USGS). A special thank you is extended to Harold A. Kantrud (USGS) who helped train the field crews in Stewart and Kantrud's (1971) wetland classification system. Amy L. Zimmerman (USGS) helped develop the Geographic Information System database of wetland locations. Robert O. Woodward (USGS) assisted with creating the maps for this publication. We thank Susan J. Anderson, Wesley E. Newton, and Michael Whitt (USGS) for their insight with the current or earlier analyses. Finally, we thank Jane E. Austin (USGS) and Steve E. Fairbairn (USFWS) for their constructive comments on an earlier draft of this report. 


\section{Contents}

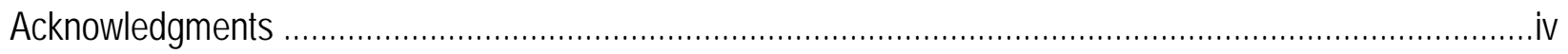

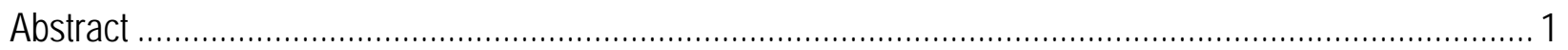

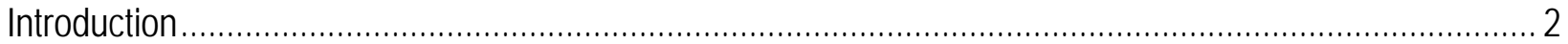

Study Area —The Prairie Pothole Region, North and South Dakota ……................................................ 3

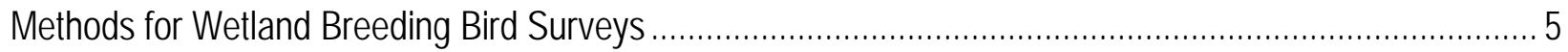

Data Analysis to Assess the Influence of Local- and Landscape-Level Factors ......................................... 7

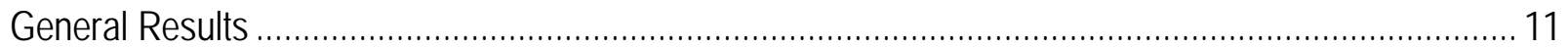

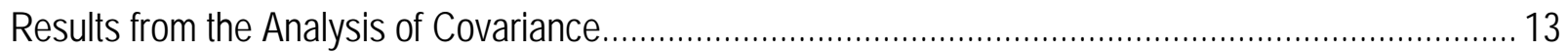

Influence of Wetland- and Landscape-Level Covariates ............................................................... 19

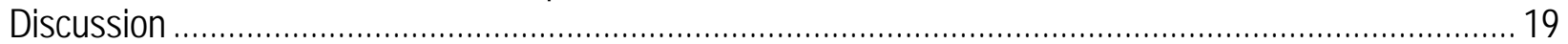

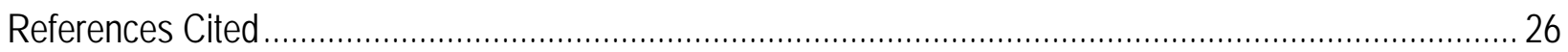

Appendix 1. Summary Statistics for Wetland Breeding Bird Study in the Prairie Pothole Region of North and South Dakota in 1995-97 ................................................................................................. 34

\section{Figures}

Figure 1. Headquarter locations for 16 Wetland Management Districts of the U.S. Fish and Wildlife Service in the Prairie Pothole Region of North and South Dakota in 1995-97.

Figure 2. Distribution of 1,190 wetlands that were surveyed to evaluate the association of wetland- and landscape-level factors with wetland bird abundances in the Prairie Pothole Region of North and South Dakota in 1995-97. Clusters of wetlands reflect their associations with U.S. Fish and Wildlife Service's Wetland Management Districts (fig. 1).

Figure 3. Plots of the number of breeding pairs compared to wetland size for each focal wetland bird species in the Prairie Pothole Region of North Dakota and South Dakota in 1995-97. Separate lines are graphed for each class, class-by-owner combination, or overall (if no class differences were detected in the analysis of covariance). For each line, Julian date, easting, and northing were held at their mean values, and intercepts were averaged across wetland types and owners (if not important). For overall lines for Gadwall and Savannah Sparrow, intercepts were averaged across all wetland classes, types, and owners. [Perm, permanent; Semi or Semiperm, Semipermanent; Seas, Seasonal; Temp, Temporary; Alk, Alkali; Fed, Federal; Priv, Private].....

Figure 4. Plots of the number of pairs compared to Julian date for each wetland bird species in the Prairie Pothole Region of North and South Dakota in 1995-97. Separate lines are graphed for each wetland type, owner, type-by-owner, or overall (depending on results of the analysis of covariance). For each line, wetland size, easting, and northing were held at their mean values and intercepts were averaged across factors not included in plot. For overall lines for Mallard, Red-winged Blackbird, Yellow-headed Blackbird, and Savannah Sparrow, intercepts were averaged across all wetland classes, types, and owners. [Rest, Restored; Nat, Natural; h'ded, headed]. 


\section{Tables}

Table 1. Summary of wetland- and landscape-level explanatory variables used in statistical analyses to model abundance of breeding birds in wetlands within the Prairie Pothole Region of North and South Dakota in 1995-97.

Table 2. Number of wetlands surveyed within each combination of wetland class, wetland type, and landowner group; and total number of pairs observed within each combination for nine focal species in the Prairie Pothole Region of North and South Dakota in 1995-97.

Table 3. Results from the analysis of covariance models to assess the effects of wetland class, wetland type, and landowner group on the number of breeding pairs of nine focal species, while accounting for wetland size, date of survey, and wetland location (easting and northing) in the Prairie Pothole Region of North and South Dakota in 1995-97.

Table 4. Information-theoretic results for assessing effects of wetland and landscape variables on the number of breeding pairs of nine focal species ( $n=1,190$ wetlands) in the Prairie Pothole Region of North and South Dakota in 1995-97.

\section{Appendix Tables}

Table 1-1. Total number of indicated breeding pairs observed in 1,190 wetland basins within the Prairie Pothole Region of North and South Dakota in 1995-97.

Table 1-2. Proportion of wetlands in which each species was present surveyed in the Prairie Pothole Region of North and South Dakota in 1995-97.

Table 1-3. Summary of wetland- and landscape-level variables overall and by wetland class (alkali, permanent, semipermanent, seasonal, or temporary), wetland type (natural or restored), and landowner group (private or Federal), including mean, standard error, and range, in the Prairie Pothole Region of North and South Dakota in 1995-97.

Table 1-4. Summary of wetland- and landscape-level variables for each species, including mean, standard error, and range, in the Prairie Pothole Region of North and South Dakota in 1995-97. 


\section{Conversion Factors}

International System of Units to U.S. customary units

\begin{tabular}{lll}
\hline \multicolumn{1}{c}{ Multiply } & \multicolumn{1}{c}{ By } & \multicolumn{1}{c}{ To obtain } \\
\hline meter $(\mathrm{m})$ & \multicolumn{2}{c}{ Length } \\
kilometer $(\mathrm{km})$ & 0.6214 & foot $(\mathrm{ft})$ \\
& \multicolumn{2}{c}{ Area } \\
\hline hectare (ha) & 2.471 & acre \\
hectare (ha) & 0.003861 & square mile $\left(\mathrm{mi}^{2}\right)$ \\
square kilometer $\left(\mathrm{km}^{2}\right)$ & 0.3861 & square mile $\left(\mathrm{mi}^{2}\right)$ \\
\hline \multicolumn{2}{c}{ Flow rate } \\
\hline kilometer per hour $(\mathrm{km} / \mathrm{h})$ & 0.6214 & mile per hour $(\mathrm{mi} / \mathrm{h})$ \\
\hline
\end{tabular}

\section{Datum}

Vertical coordinate information is referenced to the North American Vertical Datum of 1988 (NAVD 88). Horizontal coordinate information is referenced to the North American Datum of 1983 (NAD 83).

\section{Abbreviations}

AIC $\quad$ Akaike's Information Criteria for small sample sizes

$\triangle A I C_{C} \quad$ the difference between the model with the lowest $A I C_{C}$ and each subsequent model

ANCOVA analysis of covariance

EMAP Environmental Monitoring and Assessment Program

EV percentage of the wetland in emergent vegetation

Grass800 percentage of grassland area within 800 meters

HAPET Habitat and Population Evaluation Team

Numwet800 number of wetlands within 800 meters

NWI National Wetlands Inventory

OW percentage of the wetland in open water

$p$-value probability value

$R^{2} \quad$ coefficient of determination

USFWS U.S. Fish and Wildlife Service

w Akaike weight

Wetland800 percentage wetland area within 800 meters

WM percentage of the wetland in wet meadow

WMD Wetland Management District 


\title{
The Influence of Local- and Landscape-Level Factors on Wetland Breeding Birds in the Prairie Pothole Region of North and South Dakota
}

\author{
By Lawrence D. Igl, Jill A. Shaffer, Douglas H. Johnson, and Deborah A. Buhl
}

\begin{abstract}
We examined the relationship between local- (wetland) and landscape-level factors and breeding bird abundances on 1,190 depressional wetlands in the Prairie Pothole Region of North and South Dakota during the breeding seasons in 1995-97. The surveyed wetlands were selected from five wetland classes (alkali, permanent, semipermanent, seasonal, or temporary), two wetland types (natural or restored), and two landowner groups (private or Federal). We recorded 133 species of birds in the surveyed wetlands during the 3 years. We analyzed the nine most common (or focal) species (that is, species that were present in 25 percent or more of the 1,190 wetlands): the Red-winged Blackbird (Agelaius phoeniceus), Blue-winged Teal (Anas discors), Mallard (Anas platyrhynchos), American Coot (Fulica americana), Gadwall (Anas strepera), Common Yellowthroat (Geothlypis trichas), Yellow-headed Blackbird (Xanthocephalus xanthocephalus), Northern Shoveler (Anas clypeata), and Savannah Sparrow (Passerculus sandwichensis). Our results emphasize the ecological value of all wetland classes, natural and restored wetlands, and publicly and privately owned wetlands in this region, including wetlands that are generally smaller and shallower (that is, temporary and seasonal wetlands) and thus most vulnerable to drainage. Blue-winged Teal, Northern Shoveler, Gadwall, Common Yellowthroat, and Red-winged Blackbird had higher abundances on Federal than on private wetlands. Abundances differed among wetland classes for seven of the nine focal species: Blue-winged Teal, Northern Shoveler, Mallard, American Coot, Common Yellowthroat, Yellow-headed Blackbird, Red-winged Blackbird. American Coot had higher abundances on restored wetlands than on natural wetlands overall, and Gadwall and Common Yellowthroat had higher abundances on private restored wetlands than on private natural wetlands. The Common Yellowthroat was the only species that had higher abundances on restored private wetlands than on restored Federal wetlands. After adjusting for wetland size and the date and location of the surveys, our results demonstrated that incorporating wetland- and landscape-level factors in models can improve our ability to predict abundances of wetland birds in this region. The top model for eight of the nine focal species included wetland- and landscape-level factors, whereas the best model for Blue-winged Teal included only wetland-level attributes. Although local factors (for example, percent open water or emergent vegetation) in individual wetlands are important factors for some wetland breeding birds, it is important that natural resource managers consider landscape-level factors beyond the local factors in their conservation plans for wetland birds.
\end{abstract}




\section{Introduction}

Wetlands are among the most productive and diverse natural ecosystems in the world (Whittaker and Likens, 1973; Gibbs, 1993; Sebastián-González and Green, 2016). They currently occupy about 5-8 percent of the Earth's surface (Mitsch and Gosselink, 2000) and 5.5 percent of the conterminous United States (Dahl, 2014). Wetlands provide numerous ecosystem services including carbon storage, shoreline stabilization, groundwater recharge, water purification, flood and erosion control, nutrient retention, food production, and fish and wildlife habitat (Gleason and others, 2008; Mushet, 2016).

The Prairie Pothole Region of North America is a biologically diverse and unique wetland-grassland ecosystem (Baldassarre and Bolen, 2006). The prairie potholes, or depressional wetlands, in this region contain water for various lengths of time within a year (Kantrud and others, 1989a, 1989b). Size, hydrology, water chemistry, plant associations, and invertebrate communities vary widely among wetlands and, within a wetland, through time (Kantrud and others, 1989a, 1989b). Most wetlands in this region are less than $(<) 0.5$ hectare (ha) in size, and wetland density in some areas of the Prairie Pothole Region may exceed 40 wetlands per square kilometer ( $\mathrm{km}^{2}$ ) (Kantrud and others, 1989a; Johnson and others, 1997).

The Prairie Pothole Region is considered one the most intensively managed agricultural areas in the United States (Peterson and others, 1997; Higgins and others, 2002), primarily because of its productive soils and the ease with which this landscape can be altered (Hoekstra and others, 2005; Doherty and others, 2013). As such, wetland drainage and degradation in the Prairie Pothole Region have been extensive; the area of wetlands in the Prairie Pothole Region has declined by nearly 61 percent since settlement (Dahl, 2014). The Prairie Pothole Region currently contains about 5.8 percent of the total area of wetlands in the conterminous United States (Dahl, 2014). In 2009, there were an estimated 2,602,166 ha of wetland habitat in the Prairie Pothole Region in the United States, representing 6.7 percent of the total surface area of the region. Wetlands make up 9 and 8.5 percent of the surface area in the Prairie Pothole Region of North and South Dakota (fig. 1), respectively (Dahl, 2014).

Despite losses and degradation of wetlands in this region, as well as losses of adjacent native grasslands (Higgins and others, 2002; Stephens and others, 2008; Rashford and others, 2011; Doherty and others, 2013), the Prairie Pothole Region remains an area of high ecological importance. The wetlands in this region are critically important for breeding and migrating waterfowl and other wetland-dependent birds (Peterson and others, 1997; Beyersbergen and others, 2004; Baldassarre and Bolen, 2006; Skagen and Thompson, 2013). The Prairie Pothole Region supports more than 50 percent of the continent's breeding population of eight species of ducks; nearly 70 percent of the continental population of Franklin's Gull (Leucophaeus pipixcan); more than 50 percent of the continental populations of Pied-billed Grebe (Podilymbus podiceps), American Bittern (Botaurus lentiginosus), Sora (Porzana carolina), American Coot (Fulica americana), and Black Tern (Chlidonia niger); and about 30 percent of the continental populations of American White Pelican (Pelecanus erythrorhynchos) and California Gull (Larus californicus) (Batt and others, 1989; Beyersbergen and others, 2004; Niemuth and others, 2008). Several wetland bird species in this region have been listed as species of high conservation concern in the Northern Prairie and Parkland Waterbird Conservation Plan (Beyersbergen and others, 2004), in several State Wildlife Action Plans in the northern Great Plains (for example, South Dakota: South Dakota Department of Game, Fish and Parks, 2014; North Dakota: Dyke and others, 2015), and by the U.S. Fish and Wildlife Service (USFWS) in the Prairie Pothole Region (USFWS, 2008). 
There is a continued need for information on the habitat requirements at local (wetland) and landscape levels for all wetland birds in the Prairie Pothole Region (Beyersbergen and others, 2004). In 1995, we began a 3-year study of wetland birds using depressional wetlands in the Prairie Pothole Region of North and South Dakota (fig. 1). The surveyed wetlands were selected from five wetland classes (alkali, permanent, semipermanent, seasonal, or temporary; Stewart and Kantrud, 1971), two wetland types (restored or natural), and two landowner groups (private or Federal land; also referred to as owners or landowners). The objective of this study was to examine the relationship between wetland- and landscape-level factors and breeding bird abundance in wetlands in the Prairie Pothole Region in North and South Dakota. The full dataset used for analyses can be found in Igl and others (2017).

\section{Study Area-The Prairie Pothole Region, North and South Dakota}

This study was conducted in the Prairie Pothole Region of North and South Dakota (fig. 1). The Prairie Pothole Region in these two States lies east and north of the Missouri River. This formerly glaciated landscape is characterized by numerous wetlands (Cowardin and others, 1979; Bluemle, 2000), ranging from wet meadows, fens, and seasonal wetlands to permanent alkali or freshwater lakes (Stewart and Kantrud, 1971; Cowardin and others, 1979). Agriculture is the primary land use in the Dakotas, with cropland being the dominant land cover in the eastern Dakotas and rangeland increasing westward (Niemuth and others, 2010). Precipitation in this region can be highly variable from 1 year to the next; for example, the period between 1988 and mid-1993 was the second driest period in North Dakota during the 20th century, whereas the period between mid-1993 and 1999 (that is, during this study) may have been the wettest period in North Dakota during the past 130-500 years (Williams-Sether and others, 1994; WilliamsSether, 1999; Winter and Rosenberry, 1998; National Oceanic and Atmospheric Administration, 2017).

Natural and restored wetlands were identified and located on private lands and on Federal National Wildlife Refuges and Waterfowl Production Areas managed by the USFWS. In 1995, bird surveys were restricted to wetlands in North Dakota; additional wetlands from North and South Dakota were added in 1996 and 1997. The following USFWS Wetland Management Districts (WMDs) were included in this study: Arrowwood WMD (1995-97), Audubon WMD (1996-97), Chase Lake WMD (1995-97), Des Lacs WMD (1995-96), Devils Lake WMD (1995-97), J. Clark Salyer WMD (1996-97), Kulm WMD (1995-96), Long Lake WMD (199597), Lostwood WMD (1995-97), Tewaukon WMD (1996-97), and Valley City WMD (199596) in North Dakota; and Huron WMD (1996-97), Lake Andes WMD (1997), Madison WMD (1997), Sand Lake WMD (1996-97), and Waubay WMD (1996-97) in South Dakota (fig. 1).

Initially, in 1995, we selected some focal wetlands on private and Federal lands within 40-km ${ }^{2}$ hexagons that were established in the region by the U.S. Environmental Protection Agency's Environmental Monitoring and Assessment Program (EMAP) to monitor wetland condition (Kantrud and Newton, 1996; Peterson and others, 1997), and later used in the mid1990s by several studies conducted by the U.S. Geological Survey Northern Prairie Wildlife Research Center's Grasslands Ecosystem Initiative (Johnson and Batie, 2001; Browder and others, 2002; this study). For wetlands on Federal lands, field personnel visited individual WMD offices of the USFWS to identify Waterfowl Production Areas and National Wildlife Refuge lands that contained a range of wetland sizes in five wetland classes (alkali, permanent, 


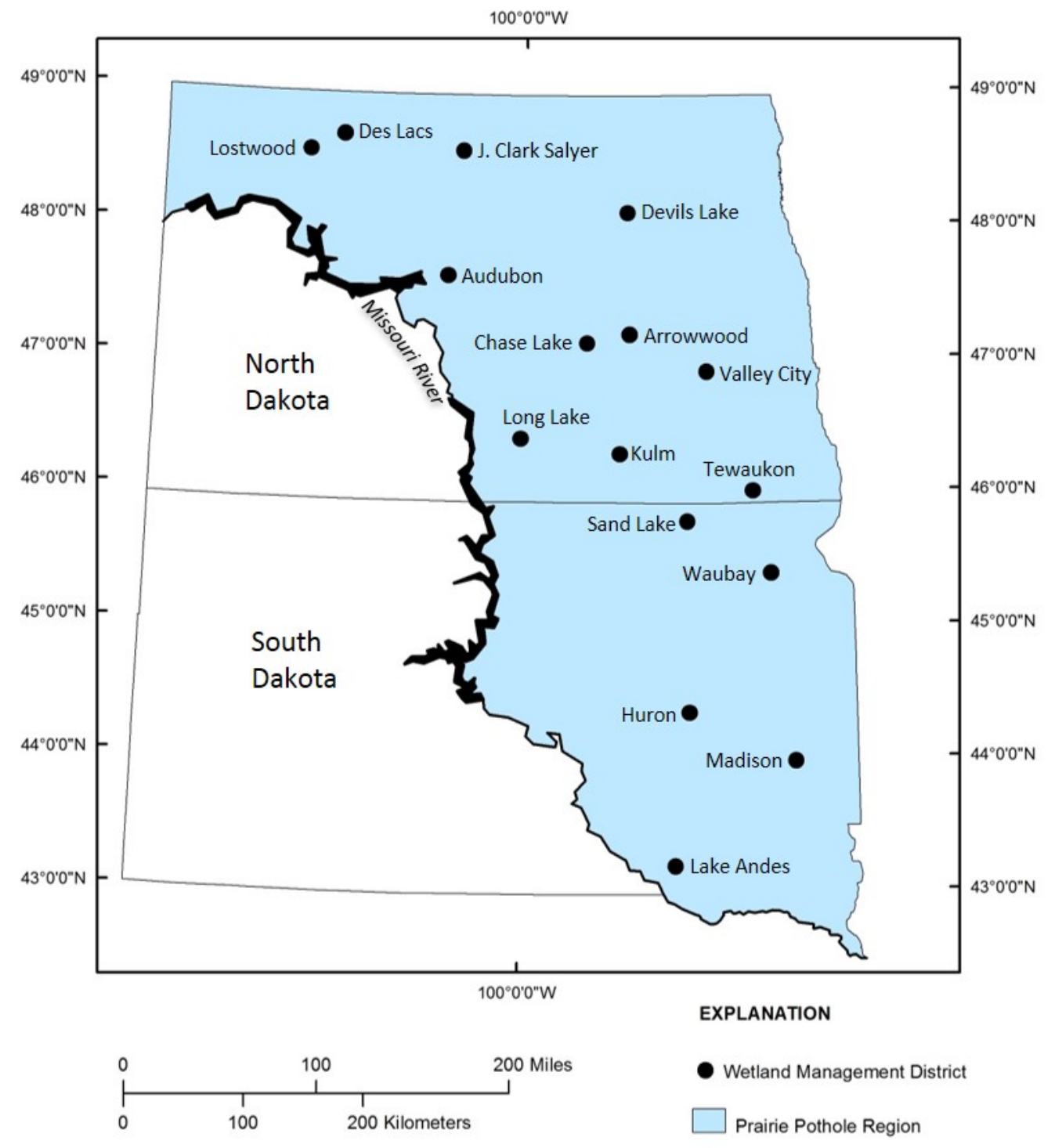

Figure 1. Headquarter locations for 16 Wetland Management Districts of the U.S. Fish and Wildlife Service in the Prairie Pothole Region of North and South Dakota in 1995-97.

semipermanent, seasonal, and temporary) as defined by Stewart and Kantrud (1971). During the visits to WMD offices, field personnel also obtained information and locations of wetlands on privately or federally owned lands that had been previously drained or cultivated and later restored. We selected wetlands that had been restored several years before this study because they afforded more mature cover and thus a better perspective on wetland- and landscape-level effects rather than transient effects related to the number of years after restoration (VanReesSiewert and Dinsmore, 1996). Several tilled wetlands (that is, wetlands that are farmed during 
dry periods) were surveyed in 2 of the 3 years, but they were excluded from the analyses because of small sample sizes. Created wetlands were not included in this study. We obtained written permission from private landowners or operators to survey breeding birds on their wetlands and secured special-use permits from the USFWS to conduct bird surveys on Federal lands.

\section{Methods for Wetland Breeding Bird Surveys}

Total-area counts of breeding birds in wetlands were conducted in 1995-97 using a minor modification of the survey methods for wetland birds described by Stewart and Kantrud (1972) and Igl and Johnson (1997). Before conducting field work, observers were trained in wetland classification (Stewart and Kantrud, 1971; Harold A. Kantrud, U.S. Geological Survey, oral commun.) and regional bird identification (aural and visual). We surveyed breeding birds from early May to early July in each year, which coincides with the peak breeding season of wetland breeding birds in the Prairie Pothole Region (Stewart and Kantrud, 1972; Stewart, 1975; Kantrud and Stewart, 1984; Igl and Johnson, 1997). Breeding birds were surveyed between one-half hour before sunrise and the midday lull in bird activity in wetlands, which varies from day to day but usually occurs in the early afternoon in this region (about 1400 Central Standard Time). We avoided surveying birds in adverse weather conditions (for example, heavy precipitation or sustained winds stronger than 40 kilometers per hour), although surveying during light drizzle or misting on calm days was allowed if birds were still active. Stewart and Kantrud (1972) and Igl and Johnson (1997) used less restrictive standards related to wind speed in open habitats (for example, grasslands and wetlands) to provide observers with more time and dates to complete bird surveys in this region. Other researchers also have used less restrictive standards for bird surveys in prairie regions (Robbins and others, 1986; Martin and others, 1997).

The study sites included a wide range of wetland sizes. Small wetlands usually were surveyed by a single observer; large wetlands typically were surveyed simultaneously by two observers, each surveying about one-half of the wetland. Large or wide-ranging birds (for example, raptors, herons, and waterfowl) that flushed from the wetland upon an observer's arrival at the focal wetland were recorded as being within the wetland. Following Stewart and Kantrud's (1972) recommendations, species (for example, raptors, waterfowl, herons, grebes, and coots) on open water that were likely to fly or seek cover upon closer approach were counted from the shoreline or a high vantage point before entering a wetland. Birds using emergent vegetation and the shoreline or mudflat were surveyed while walking the wetland perimeter. In narrow zones of emergent vegetation, the observer attempted to flush large species (for example, ducks and herons) and secretive species (for example, rails and bitterns) by wading through the wetland vegetation. In large zones of emergent vegetation, the observer waded in a zigzag course throughout the wetland. In wetlands that were surveyed by two observers, observers compared field notes at the end of the survey to prevent duplication in the counts.

Taped calls of seven secretive marsh bird species were broadcast during the survey of a wetland to elicit responses (Delphey and Dinsmore, 1993; Gibbs and Melvin, 1993; Ribic and others, 1999). The broadcast tape was 5 minutes in length and included common calls, 26-50 seconds in length, of each focal species. The order of the species on the tape was as follows: Sora, Yellow Rail (Coturnicops noveboracensis), Virginia Rail (Rallus limicola), American Coot, Pied-billed Grebe, American Bittern, and Least Bittern (Ixobrychus exilis). The broadcast calls were played once at small wetlands and multiple times at larger wetlands, such that the entire wetland was covered. After the calls were broadcast, the observers remained briefly at the location of the broadcast to record any responses by the focal species. 
Counts of birds were based primarily on the number of indicated breeding pairs on territories or home ranges or by the presence of active nests. For most species, nearly all indicated pairs were observed as territorial males or as segregated pairs. In the case of wideranging or colonial-nesting species that are not sexually dimorphic or dichromatic (for example, shorebirds, coots, grebes, and swallows), one or two individuals were considered to represent a pair, but if more than two individuals were observed on a wetland, the total number of indicated pairs was derived by halving the total number of individuals counted and rounding up to the nearest whole pair. For the polyandrous Wilson's Phalarope (Phalaropus tricolor), segregated pairs and lone females were recorded as indicated pairs. For the polygynous Red-winged (Agelaius phoeniceus) and Yellow-headed (Xanthocephalus xanthocephalus) blackbirds, the number of breeding pairs was based on the number of males and represented, in terms of breeding mates, a minimum population. For the brood parasitic Brown-headed Cowbird (Molothrus ater), we based the number of indicated pairs on the total number of females. Birds that were flying overhead were counted only if their flight originated or terminated in the wetland, their attempt to alight in the wetland was deterred because of the presence of an observer, or they were using the wetland while in flight, such as for flycatching or hunting, courtship or communal displaying, and so on.

The procedures used to determine the number of pairs of breeding waterfowl followed Hammond (1969). In general, single pairs, lone males of dabblers or divers, and lone females of diving ducks were considered as an indicated pair. Occasionally, the number of lone female ducks on a wetland exceeded the number of males unaccompanied by females. In this case, each excess lone female was considered to represent a pair.

We did not consider certain birds observed during the surveys to be using the wetlands and excluded them from our results. These included wide-ranging colonial waterbirds (for example, pelicans, cormorants, egrets, and herons) passing high overhead, and other birds passing overhead in high, direct flight. Juveniles were recorded but not considered part of the breeding population at a site; however, a single adult or a pair of adults accompanied by a one or more juveniles was counted as a single pair. In total, 20 observed pairs (about 0.05 percent of total breeding pairs observed) were not identified to the species level and were excluded from analyses and in summary statistics. Vernacular and scientific names follow the checklist of the American Ornithologists' Union (1998) and subsequent supplements. Scientific names and fourletter alpha codes for all species observed during this study are included in appendix tables 1-1 and $1-2$, respectively.

Some wetlands, including those in EMAP hexagons, were surveyed in more than 1 year. For each wetland surveyed, the size of the wetland was estimated primarily by field personnel, although some wetland sizes were obtained from the U.S. Geological Survey's Northern Prairie Wildlife Research Center as part of the U.S. Environmental Protection Agency's EMAP effort, or determined from the USFWS's National Wetlands Inventory (NWI) database (Wilen and Bates, 1995). During field work in each year, field personnel also estimated the percentage cover of major wetland zones (Stewart and Kantrud, 1971; Cowardin and others, 1979) for each wetland. The number of wetland zones and the definitions of some wetland zones changed among years, which resulted in some wetland zones being collapsed into a broader category before statistical analyses. The final four wetland zones included open water, emergent vegetation (for example, cattail [Typha spp.], bulrush [Cyperaceae], flooded shrubs [for example, Salix spp.]), wet meadow (for example, fine-textured grasses [Poaceae], rushes [Juncaceae], and 
sedges [Cyperaceae]), and shoreline/mudflat. Each breeding pair was recorded as present within one of these four wetland zones (see appendix table 1-4).

To evaluate the effects of landscape variables on wetland bird abundance, we identified the location of the surveyed wetlands in the NWI database (Wilen and Bates, 1995). Delineated wetlands in the NWI database were converted to individual depressional wetlands by dissolving arcs and classifying the wetland by the most permanent water regime, using techniques described by Cowardin and others (1995) and Johnson and Higgins (1997). Wetlands were then classified as alkali, permanent, semipermanent, seasonal, or temporary, using the wetland classification system and terminology developed by Stewart and Kantrud (1971).

Upland habitats in the landscape surrounding the surveyed wetlands were classified by the USFWS's Habitat and Population Evaluation Team (HAPET) using Landsat Thematic Mapper imagery (https://ta.cr.usgs.gov/TM) into four major categories: agriculture (that is, row crop, small grains, and fallow), undisturbed grasses (for example, Conservation Reserve Program grasslands and dense nesting cover), mature forest, and native grasses and scattered low shrubs. We also determined the number of disjunct wetlands and the number of wetland water regimes (temporary, seasonal, semipermanent, permanent, riverine, and unmapped), using information from the NWI database. We sampled landscape habitat at three scales using a circular movingwindow analysis, which summarizes data within a window of a selected size around each $30 \times 30$ meter (m) cell in a Geographical Information System data layer (Niemuth and others, 2008). The landscape data were in raster format, and the area within each moving window was about 48, 191, and 452 ha, respectively, for circles with radii about 400, 800, and 1,200 m.

\section{Data Analysis to Assess the Influence of Local- and Landscape-Level Factors}

Data from the wetland bird surveys were analyzed to assess the relationship of wetlandand landscape-level factors with abundance of wetland bird species. As mentioned above, the surveyed wetlands were selected from five wetland classes (alkali, permanent, semipermanent, seasonal, or temporary; Stewart and Kantrud, 1971), two wetland types (natural or restored), and two landowner groups (private or Federal land). Some wetlands were surveyed in multiple years, but it was not always clear which wetlands were surveyed multiple times across years. This was, in part, due to the heavy precipitation preceding and during the survey period (Williams-Sether and others, 1994; Williams-Sether, 1999; Winter and Rosenberry, 1998) that resulted in rapid changes in size and classification of individual wetlands, as well as the amalgamation of multiple smaller wetlands into a single larger wetland (for example, see Igl, 2004). For the purpose of our analyses, each wetland in each year was considered a unique wetland, giving a total of 1,291 wetlands surveyed.

Each wetland was surveyed either once or twice within a year; most wetlands were surveyed only once. For those wetlands that were surveyed twice, only the second survey was used in the analyses. During each survey, the number of indicated pairs for each species present was recorded within each wetland zone of the wetland; however, because the number of zones and their definitions changed across years, the number of pairs by zone was not used in the analyses; rather, the total number of pairs of each species within the wetland was computed and used as the response variable in the analyses.

In addition to wetland class, type, and owner, several wetland-level (for example, wetland size, percent of wetland in various zones, percent of wetland with water, and location) and 
landscape-level (that is, surrounding cover) explanatory variables were measured for each wetland. Landscape-level explanatory variables obtained from HAPET for the area within 400, 800 , and 1,200 $\mathrm{m}$ of each wetland included the percent of the area within various cover types and the number of wetlands, but were only available for 1,190 of the 1,291 wetlands. Based on the range of values within variables, correlations among variables, completeness of data, and expert opinion, the pool of explanatory variables was reduced down to the variables listed in table 1 . For each landscape-level explanatory variable within 400, 800, and $1200 \mathrm{~m}$ of each wetland, the measurements at one scale were highly correlated with the measurements at the other two scales; therefore, only one scale for the landscape variables was retained for analyses. We chose the 800-m scale because it would likely identify the landscape that wetland birds perceive near the focal wetlands (Niemuth and others, 2006). Percentage of grassland and percentage of agricultural land within the landscape were very highly correlated $(r=-0.88)$, so only the percentage of grassland within $800 \mathrm{~m}$ was retained. Given that we lacked landscape-level data for some surveyed wetlands (including all wetlands in Audubon, Chase Lake, Des Lacs, and Valley City WMDs in 1995; and all wetlands in Arrowwood WMD in 1996; fig. 1), the final set of data used for analyses only included 1,190 wetlands (fig. 2).

Analysis of covariance (ANCOVA; Milliken and Johnson, 2002) methods were used to test for differences in the number of breeding bird pairs for each species among wetland classes, types, owners, and their interactions while adjusting for wetland size (which was natural logarithm transformed), date of survey (Julian date), and location of wetland (easting and northing). Date of survey was included in the ANCOVA because peak breeding periods vary among wetland bird species (Stewart and Kantrud, 1972; Igl and Johnson, 1997). Easting and northing were rescaled to improve numerical stability and convergence of models (table 1). For all covariates, a common slope was assumed across all levels of wetland class, type, and owner. The ANCOVAs were completed using PROC GLIMMIX of SAS ${ }^{\circledR}$ (SAS Institute, 2015) with the number of breeding pairs as the response variable and by specifying a negative binomial error distribution with a log link function (Hilbe, 2011). This analysis was completed for the nine most common bird species observed (that is, species that occurred in 25 percent or more of the 1,190 wetlands); in order of abundance, these were the Red-winged Blackbird, Blue-winged Teal (Anas discors), Mallard (Anas platyrhynchos), American Coot, Gadwall (Anas strepera), Common Yellowthroat (Geothlypis trichas), Yellow-headed Blackbird, Northern Shoveler (Anas clypeata), and Savannah Sparrow (Passerculus sandwichensis). For the latter three species, there were one or two combinations of wetland class, type, and owner at which no breeding pairs were observed (table 2); therefore, for these three species the three-way interaction term was not included in the model (table 3). Least squares means were computed for all main effects and for interaction terms with probability values ( $p$-values) $<0.05$. Differences in least squares were tested using Fisher's least significant differences (Milliken and Johnson, 2002); two least squares means were interpreted as significantly different if the $p$-value was $<0.05$. Only significant findings were reported for tests using Fisher's least significant differences.

An information theoretic approach was used to compare 18 candidate models to assess the relationship between the number of indicated breeding pairs and the wetland- and landscapelevel variables for the nine focal species. For each species, candidate models were constructed by first including the variables deemed significant (that is, $p$-value $<0.05$ ) from the previous ANCOVA for that species; however, if a main effect and an interaction effect involving that variable were both significant, only the interaction effect was included in these models. Then 
Table 1. Summary of wetland- and landscape-level explanatory variables used in statistical analyses to model abundance of breeding birds in wetlands within the Prairie Pothole Region of North and South Dakota in 1995-97.

\begin{tabular}{|c|c|c|c|c|c|c|}
\hline Variable & Description & Mean & Standard error & Minimum & Median & Maximum \\
\hline \multicolumn{7}{|c|}{ Wetland-level variables } \\
\hline Class & $\begin{array}{l}\text { Wetland class (alkali, permanent, semipermanent, seasonal, or } \\
\text { temporary) }\end{array}$ & \multicolumn{5}{|c|}{ Categorical variable } \\
\hline Wtype & Wetland type (natural or restored) & \multicolumn{5}{|c|}{ Categorical variable } \\
\hline Owner & Landowner group (private or Federal) & \multicolumn{5}{|c|}{ Categorical variable } \\
\hline Lsize & Log-transformed (natural logarithm) wetland size (hectares) & -0.333 & 0.050 & -4.605 & -0.693 & 5.319 \\
\hline Juldate & Julian date of survey & 165.987 & 0.334 & 138 & 166 & 184 \\
\hline East & $\begin{array}{l}\text { Rescaled easting (rescaled as [easting - } \\
\text { minimum(easting)]/1,000) }\end{array}$ & 323.429 & 3.003 & 0 & 315.087 & 508.529 \\
\hline North & $\begin{array}{l}\text { Rescaled northing (rescaled as [northing - } \\
\text { minimum(northing)]/1,000) }\end{array}$ & 358.634 & 4.493 & 0 & 331.936 & 653.666 \\
\hline OW & Percentage of the wetland in open water & 37.382 & 0.912 & 0 & 30 & 100 \\
\hline$E V^{\mathrm{a}}$ & Percentage of the wetland in emergent vegetation & 24.844 & 0.808 & 0 & 15 & 100 \\
\hline$W M^{\mathrm{a}}$ & Percentage of the wetland in wet meadow & 33.628 & 0.957 & 0 & 20 & 100 \\
\hline \multicolumn{7}{|c|}{ Landscape-level variables } \\
\hline Grass800 & Percentage grassland area within 800 meters & 56.311 & 0.655 & 0 & 60 & 97 \\
\hline Wetland800 & Percentage wetland area within 800 meters & 14.441 & 0.287 & 0 & 13 & 82 \\
\hline Numwet800 & Number of wetlands within 800 meters & 27.518 & 0.385 & 1 & 25 & 75 \\
\hline \multicolumn{7}{|c|}{ Summary statistics for wetland size, easting, and northing in original scale } \\
\hline Size & Wetland size (hectares) & 4.022 & 0.364 & 0.010 & 0.500 & 204.260 \\
\hline Easting & Easting & 510,678 & 3,003 & 187,248 & 502,335 & 695,777 \\
\hline Northing & Northing & $5,132,419$ & 4,493 & 4,773,785 & $5,105,721$ & $5,427,451$ \\
\hline
\end{tabular}

${ }^{a} E V$ was used as an explanatory variable in the analyses to model abundance for all species except Savannah Sparrow, for which $W M$ was used instead. 


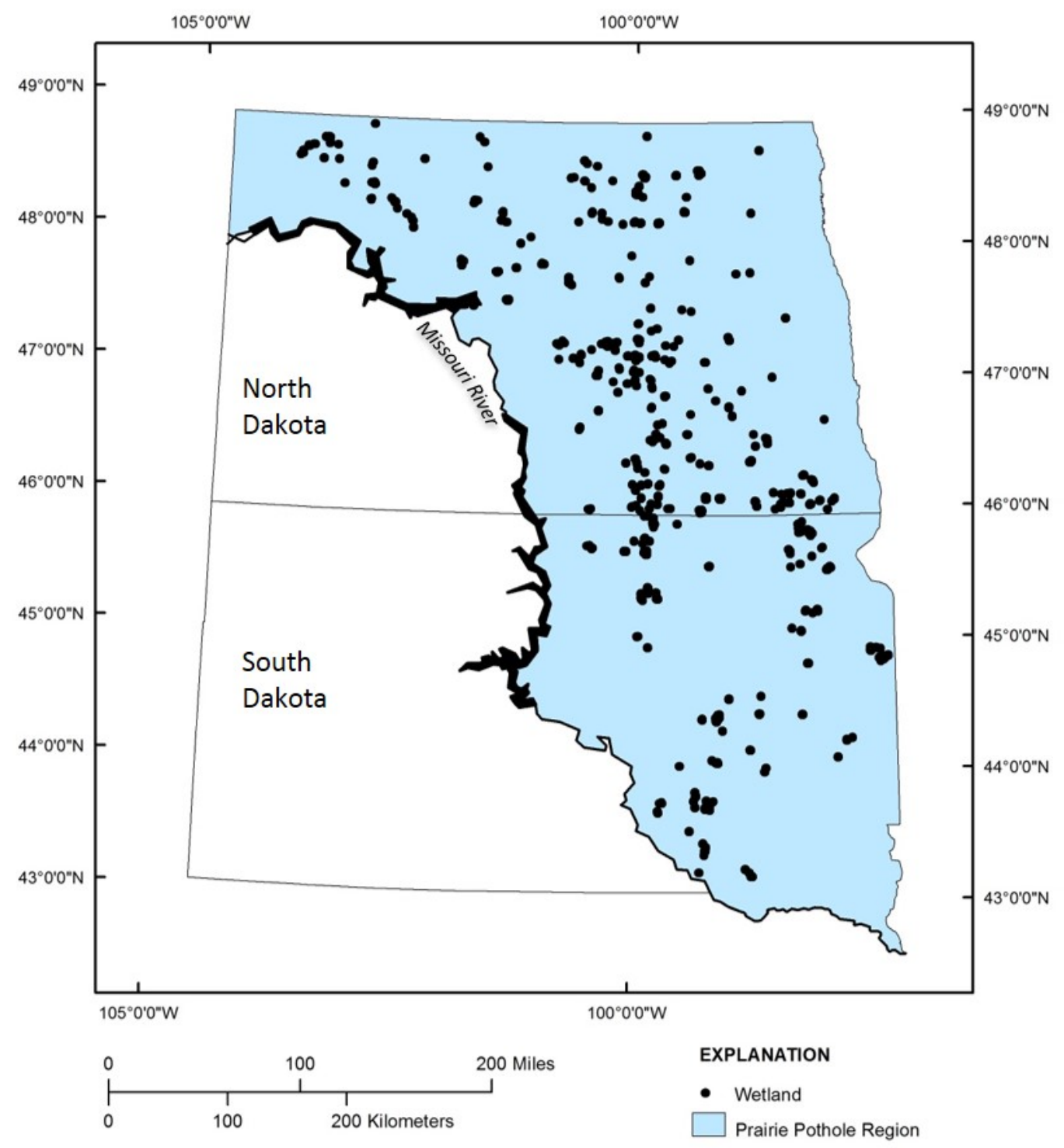

Figure 2. Distribution of 1,190 wetlands that were surveyed to evaluate the association of wetland- and landscape-level factors with wetland bird abundances in the Prairie Pothole Region of North and South Dakota in 1995-97. Clusters of wetlands reflect their associations with U.S. Fish and Wildlife Service's Wetland Management Districts (fig. 1).

added to those variables were the percentage of the wetland in open water $(\mathrm{OW})$, percentage of the wetland in emergent vegetation ( $E V$; for all species but Savannah Sparrow), percentage of the wetland in wet meadow (WM; for Savannah Sparrow only), percentage of grassland area within 
$800 \mathrm{~m}$ (Grass800), percentage of wetland area within $800 \mathrm{~m}$ (Wetland800), and the number of wetlands within $800 \mathrm{~m}$ (Numwet800) (table 1). These variables were added alone and in combination (additive effects only; no interactions were included) while avoiding the inclusion of two variables that are part of a group of variables that add up to 100 percent (for example, $O W$ and $E V$ [or WM] were not included in same model, and Grass800 and Wetland800 were not included in the same model). The 18 candidate models were:

1. Significant variables from ANCOVA

2. Significant variables from ANCOVA $+O W$

3. Significant variables from ANCOVA $+E V$ (or $W M$ )

4. Significant variables from ANCOVA + Grass800

5. Significant variables from ANCOVA + Wetland800

6. Significant variables from ANCOVA + Numwet 800

7. Significant variables from ANCOVA + Grass800 + Numwet800

8. Significant variables from ANCOVA + Wetland800 + Numwet800

9. Significant variables from ANCOVA + OW + Grass800

10. Significant variables from ANCOVA $+O W+$ Wetland800

11. Significant variables from ANCOVA $+O W+$ Numwet800

12. Significant variables from ANCOVA $+O W+$ Grass800 + Numwet 800

13. Significant variables from ANCOVA $+O W+$ Wetland $800+$ Numwet 800

14. Significant variables from ANCOVA $+E V($ or $W M)+$ Grass 800

15. Significant variables from ANCOVA $+E V($ or $W M)+$ Wetland 800

16. Significant variables from ANCOVA $+E V($ or $W M)+$ Numwet800

17. Significant variables from ANCOVA $+E V($ or $W M)+$ Grass $800+$ Numwet 800

18. Significant variables from ANCOVA $+E V($ or $W M)+$ Wetland800 + Numwet800

Akaike's Information Criteria for small sample sizes $\left(A I C_{C}\right)$, the difference between the model with the lowest $A I C_{C}$ and each subsequent model $\left(\triangle A I C_{C}\right)$, and the Akaike weight ( $w$; the relative likelihood of each model) were computed for each model (Burnham and Anderson, 2002). The coefficient of determination $\left(R^{2}\right)$, which indicates the percentage of variation in the data explained by the model, is not appropriate for count data (Hilbe, 2011); therefore, pseudo- $R^{2}$ values were computed instead. These pseudo- $R^{2}$ cannot be interpreted as one would interpret a $R^{2}$, but low pseudo- $R^{2}$ values would indicate a poor model fit whereas high values would indicate a good model fit. Plots of observed versus predicted values were constructed to assess model fit.

For all species observed, a variety of summary statistics were computed, including the total number of breeding pairs observed, the proportion of wetlands observed overall and by levels of categorical variables, and summary statistics for the wetland and landscape variables for all wetlands and for wetlands used by each species. Two wetland and landscape variables that were not included in the above analyses were included in these summaries: percentage of the wetland in shoreline/mudflat and percentage of agriculture within $800 \mathrm{~m}$.

\section{General Results}

Between May 18 and July 3, 1995-97, 37,075 indicated breeding pairs of 133 bird species were recorded on 1,190 wetlands, which included 5 wetland classes, 2 wetland types, and 2 landowner groups. Wetland size ranged from 0.01 ha to greater than 200 ha and had a mean 
Table 2. Number of wetlands surveyed within each combination of wetland class, wetland type, and landowner group; and total number of pairs observed within each combination for nine focal species in the Prairie Pothole Region of North and South Dakota in 1995-97.

[RWBL, Red-winged Blackbird; BWTE, Blue-winged Teal; MALL, Mallard; AMCO, American Coot; GADW, Gadwall; COYE, Common Yellowthroat; YHBL, Yellow-headed Blackbird; NSHO, Northern Shoveler; SAVS, Savannah Sparrow]

\begin{tabular}{|c|c|c|c|c|c|c|c|c|c|c|c|c|}
\hline \multirow{2}{*}{ Wetland class } & \multirow{2}{*}{$\begin{array}{l}\text { Wetland } \\
\text { type }\end{array}$} & \multirow{2}{*}{$\begin{array}{l}\text { Landowner } \\
\text { group }\end{array}$} & \multirow{2}{*}{$\begin{array}{l}\text { Number } \\
\text { of } \\
\text { wetlands } \\
\text { surveyed }\end{array}$} & \multicolumn{9}{|c|}{ Number of breeding pairs observed } \\
\hline & & & & RWBL & BWTE & MALL & AMCO & GADW & COYE & YHBL & NSHO & SAVS \\
\hline \multirow{4}{*}{ Alkali } & \multirow{2}{*}{ Natural } & Private & 10 & 14 & 45 & 33 & 35 & 34 & 1 & 21 & 22 & 8 \\
\hline & & Federal & 27 & 140 & 281 & 115 & 140 & 181 & 11 & 166 & 118 & 73 \\
\hline & \multirow{2}{*}{ Restored } & Private & 3 & 6 & 16 & 2 & 8 & 7 & 5 & 5 & 3 & 1 \\
\hline & & Federal & 4 & 8 & 27 & 7 & 12 & 32 & 1 & 0 & 21 & 1 \\
\hline \multirow{4}{*}{ Permanent } & \multirow{2}{*}{ Natural } & Private & 8 & 25 & 56 & 14 & 56 & 33 & 9 & 69 & 3 & 2 \\
\hline & & Federal & 33 & 392 & 427 & 194 & 474 & 248 & 71 & 638 & 60 & 34 \\
\hline & \multirow{2}{*}{ Restored } & Private & 2 & 4 & 10 & 15 & 16 & 31 & 7 & 14 & 0 & 5 \\
\hline & & Federal & 4 & 22 & 44 & 31 & 22 & 25 & 8 & 59 & 6 & 0 \\
\hline \multirow{4}{*}{ Semipermanent } & \multirow{2}{*}{ Natural } & Private & 98 & 314 & 235 & 103 & 240 & 98 & 97 & 290 & 41 & 43 \\
\hline & & Federal & 228 & 1028 & 962 & 524 & 821 & 458 & 437 & 1877 & 112 & 84 \\
\hline & \multirow{2}{*}{ Restored } & Private & 154 & 478 & 467 & 220 & 248 & 158 & 257 & 465 & 73 & 61 \\
\hline & & Federal & 44 & 173 & 193 & 92 & 84 & 73 & 72 & 257 & 54 & 26 \\
\hline \multirow{4}{*}{ Seasonal } & \multirow{2}{*}{ Natural } & Private & 100 & 196 & 293 & 78 & 147 & 78 & 19 & 48 & 70 & 32 \\
\hline & & Federal & 146 & 454 & 520 & 218 & 313 & 246 & 132 & 330 & 93 & 36 \\
\hline & \multirow{2}{*}{ Restored } & Private & 141 & 352 & 402 & 168 & 150 & 141 & 104 & 80 & 79 & 62 \\
\hline & & Federal & 23 & 50 & 56 & 21 & 34 & 16 & 24 & 105 & 13 & 14 \\
\hline \multirow{4}{*}{ Temporary } & \multirow{2}{*}{ Natural } & Private & 55 & 41 & 35 & 14 & 17 & 9 & 5 & 16 & 10 & 15 \\
\hline & & Federal & 59 & 117 & 84 & 31 & 41 & 47 & 25 & 12 & 24 & 17 \\
\hline & \multirow{2}{*}{ Restored } & Private & 39 & 23 & 18 & 7 & 1 & 11 & 11 & 2 & 4 & 19 \\
\hline & & Federal & 12 & 18 & 10 & 3 & 2 & 6 & 10 & 0 & 6 & 3 \\
\hline
\end{tabular}


(plus or minus [ \pm ] standard error) of $4.022 \pm 0.364$ (table 1 ; appendix table $1-3$ ). In total, 75 percent of the wetlands were 2.1 ha or smaller.

The 9 most abundant bird species (6.7 percent of the 133 species detected) occurred in 25 percent or more of the 1,190 wetlands (table 2; appendix table $1-1$ ). We recorded 1,000 or more breeding pairs for 10 (7.5 percent) species, and fewer than 5 pairs for 37 (27.8 percent) species (appendix table 1-1). The list of 133 species included 15 species that typically do not breed in North or South Dakota, including late-arriving spring migrants (for example, Canada Warbler [Cardellina canadensis]), vagrants that are outside of their typical breeding range (for example, White Ibis [Eudocimus albus]; Marlow and others, 1996), and some shorebirds and waterfowl that breed in the tundra and boreal regions of northern North America but may oversummer in the northern Great Plains (for example, Least Sandpiper [Calidris minutilla] and Snow Goose [Chen caerulescens]). Despite the use of broadcast calls for the Yellow Rail, the species was not recorded at any of the 1,190 wetlands during the 3 years of this study. Summary statistics for wetlands and all bird species are provided in appendix tables 1-1 through 1-4.

\section{Results from the Analysis of Covariance}

The number of breeding pairs was positively related to wetland size for all nine focal species (fig. 3), whereas the results for the other three covariates varied with species (table 3). A significant negative relationship was observed with date of survey for Red-winged Blackbird, Blue-winged Teal, American Coot, Yellow-headed Blackbird, and Northern Shoveler (fig. 4). Blue-winged Teal, Mallard, American Coot, Gadwall, and Northern Shoveler displayed a significant negative relationship between the number of pairs and easting, and one species (Common Yellowthroat) showed a significant positive relationship between the number of pairs and easting (table 3). The results for northing were similar; five species (Red-winged Blackbird, Blue-winged Teal, Mallard, Gadwall, and Common Yellowthroat) exhibited a significant negative relationship between the number of breeding pairs and northing, and one species (Savannah Sparrow) exhibited a significant positive relationship between the number of pairs and northing (table 3).

The number of pairs observed differed among wetland classes for seven of the nine species (table 3; fig. 3). Blue-winged Teal were significantly less abundant on temporary wetlands than all other wetland classes and were significantly more abundant on seasonal than semipermanent wetlands (fig. 3). The number of Mallards was significantly lower on temporary wetlands than on permanent, semipermanent, and seasonal wetlands. American Coots were significantly less abundant on alkali and temporary wetlands than on permanent, semipermanent, and seasonal wetlands. Alkali wetlands had significantly lower numbers of Common Yellowthroat pairs than permanent and semipermanent wetlands, and semipermanent wetlands had significantly higher numbers than seasonal and temporary wetlands. The Yellow-headed Blackbird was significantly less abundant on temporary wetlands than all other wetland classes, significantly less abundant on seasonal wetlands than on permanent and semipermanent wetlands, and significantly less abundant on alkali wetlands than semipermanent wetlands. Seasonal wetlands had significantly higher numbers of Northern Shoveler pairs than permanent, semipermanent, and temporary wetlands; and semipermanent wetlands had significantly higher numbers than permanent wetlands. For Red-winged Blackbird, class differences depended on the wetland owner. Temporary private wetlands had significantly fewer Red-winged Blackbird pairs than private seasonal and semipermanent wetlands; and semipermanent Federal wetlands had significantly more pairs than seasonal and alkali Federal wetlands. 
Table 3. Results from the analysis of covariance models to assess the effects of wetland class, wetland type, and landowner group on the number of breeding pairs of nine focal species, while accounting for wetland size, date of survey, and wetland location (easting and northing) in the Prairie Pothole Region of North and South Dakota in 1995-97.

[Numerator degrees of freedom for F-tests equal 4 for Class, Class*Wtype, Class*Owner, and Class*Wtype*Owner; and equal 1 for Wtype, Owner, Wtype*Owner, and all covariates. Denominator degrees of freedom for $F$-tests equal 1,166 for the first six species and equal 1,170 for the last three species (denominator degrees of freedom are higher for these three species because the three-way interaction was not included). RWBL, Red-winged Blackbird; BWTE, Blue-winged Teal; MALL, Mallard; AMCO, American Coot; GADW, Gadwall; COYE, Common Yellowthroat; YHBL, Yellow-headed Blackbird; NSHO, Northern Shoveler; SAVS, Savannah Sparrow; Class, wetland class (alkali, permanent, semipermanent, seasonal, or temporary); $F, F$-distribution statistic; $P$, $p$ value (probability); <, less than; Wtype, wetland type (natural or restored); *, interaction; Owner, landowner group (private or Federal); ---, no record; Lsize, logtransformed (natural logarithm) wetland size; Juldate, Julian date of survey; East, rescaled easting; North, rescaled northing]

\begin{tabular}{|c|c|c|c|c|c|c|c|c|c|}
\hline $\begin{array}{l}\text { Variable } \\
\text { (table 1) }\end{array}$ & RWBL & BWTE & MALL & AMCO & GADW & COYE & YHBL & NSHO & SAVS \\
\hline Class & $\begin{array}{l}F=5.19, \\
P=0.0004\end{array}$ & $\begin{array}{l}F=8.30, \\
P<0.0001\end{array}$ & $\begin{array}{l}F=4.17, \\
P=0.0023\end{array}$ & $\begin{array}{l}F=10.16 \\
P<0.0001\end{array}$ & $\begin{array}{l}F=1.88, \\
P=0.1123\end{array}$ & $\begin{array}{l}F=7.45 \\
P<0.0001\end{array}$ & $\begin{aligned} F & =28.55 \\
P & <0.0001\end{aligned}$ & $\begin{array}{l}F=5.02, \\
P=0.0005\end{array}$ & $\begin{array}{l}F=0.61, \\
P=0.6564\end{array}$ \\
\hline Wtype & $\begin{array}{l}F=0.44, \\
P=0.5080\end{array}$ & $\begin{array}{l}F=0.07, \\
P=0.7878\end{array}$ & $\begin{array}{l}F=0.41, \\
P=0.5226\end{array}$ & $\begin{array}{l}F=4.49, \\
P=0.0343\end{array}$ & $\begin{array}{l}F=3.71, \\
P=0.0543\end{array}$ & $\begin{aligned} F & =18.21, \\
P & <0.0001\end{aligned}$ & $\begin{array}{l}F=0.61, \\
P=0.4334\end{array}$ & $\begin{array}{l}F=0.02, \\
P=0.9015\end{array}$ & $\begin{array}{l}F=0.11, \\
P=0.7426\end{array}$ \\
\hline Class*Wtype & $\begin{array}{l}F=1.63, \\
P=0.1643\end{array}$ & $\begin{array}{l}F=2.25, \\
P=0.0613\end{array}$ & $\begin{array}{l}F=1.45, \\
P=0.2146\end{array}$ & $\begin{array}{l}F=1.91, \\
P=0.1060\end{array}$ & $\begin{array}{l}F=1.10, \\
P=0.3573\end{array}$ & $\begin{array}{l}F=2.26, \\
P=0.0611\end{array}$ & $\begin{array}{l}F=0.79, \\
P=0.5336\end{array}$ & $\begin{array}{l}F=1.34, \\
P=0.2540\end{array}$ & $\begin{array}{l}F=1.47, \\
P=0.2080\end{array}$ \\
\hline Owner & $\begin{array}{l}F=2.82, \\
P=0.0932\end{array}$ & $\begin{array}{l}F=1.05, \\
P=0.3063\end{array}$ & $\begin{array}{l}F=0.28, \\
P=0.6000\end{array}$ & $\begin{array}{l}F=0.01, \\
P=0.9092\end{array}$ & $\begin{array}{l}F=0.54, \\
P=0.4610\end{array}$ & $\begin{array}{l}F=0.01, \\
P=0.9170\end{array}$ & $\begin{array}{l}F=0.11, \\
P=0.7447\end{array}$ & $\begin{aligned} F & =15.16, \\
P & =0.0001\end{aligned}$ & $\begin{array}{l}F=0.11, \\
P=0.7377\end{array}$ \\
\hline Class*Owner & $\begin{array}{l}F=2.88, \\
P=0.0218\end{array}$ & $\begin{array}{l}F=0.83, \\
P=0.5081\end{array}$ & $\begin{array}{l}F=0.45, \\
P=0.7759\end{array}$ & $\begin{array}{l}F=0.92, \\
P=0.4535\end{array}$ & $\begin{array}{l}F=0.63, \\
P=0.6435\end{array}$ & $\begin{array}{l}F=2.02, \\
P=0.0893\end{array}$ & $\begin{array}{l}F=1.82, \\
P=0.1227\end{array}$ & $\begin{array}{l}F=1.66, \\
P=0.1568\end{array}$ & $\begin{array}{l}F=0.91, \\
P=0.4587\end{array}$ \\
\hline Wtype*Owner & $\begin{array}{l}F=3.13, \\
P=0.0769\end{array}$ & $\begin{array}{l}F=4.52, \\
P=0.0336\end{array}$ & $\begin{array}{l}F=2.41, \\
P=0.1208\end{array}$ & $\begin{array}{l}F=2.80, \\
P=0.0946\end{array}$ & $\begin{array}{l}F=6.27, \\
P=0.0124\end{array}$ & $\begin{array}{l}F=9.36, \\
P=0.0023\end{array}$ & $\begin{array}{l}F=0.01, \\
P=0.9091\end{array}$ & $\begin{array}{l}F=0.38, \\
P=0.5396\end{array}$ & $\begin{array}{l}F=0.02, \\
P=0.8795\end{array}$ \\
\hline Class*Wtype*Owner & $\begin{array}{l}F=1.60, \\
P=0.1713\end{array}$ & $\begin{array}{l}F=0.69, \\
P=0.5984\end{array}$ & $\begin{array}{l}F=0.45, \\
P=0.7753\end{array}$ & $\begin{array}{l}F=1.05, \\
P=0.3801\end{array}$ & $\begin{array}{l}F=1.53, \\
P=0.1900\end{array}$ & $\begin{array}{l}F=1.30, \\
P=0.2677\end{array}$ & --- & --- & --- \\
\hline Lsize & $\begin{array}{r}F=369.47 \\
P<0.0001\end{array}$ & $\begin{array}{r}F=483.03 \\
P<0.0001\end{array}$ & $\begin{array}{r}F=272.94 \\
P<0.0001\end{array}$ & $\begin{array}{r}F=450.87 \\
P<0.0001\end{array}$ & $\begin{array}{r}F=318.53 \\
P<0.0001\end{array}$ & $\begin{array}{r}F=161.98 \\
P<0.0001\end{array}$ & $\begin{array}{r}F=300.02, \\
P<0.0001\end{array}$ & $\begin{array}{r}F=117.40 \\
P<0.0001\end{array}$ & $\begin{aligned} F & =54.56, \\
P & <0.0001\end{aligned}$ \\
\hline Juldate & $\begin{array}{l}F=5.27, \\
P=0.0218\end{array}$ & $\begin{array}{l}F=42.16, \\
P<0.0001\end{array}$ & $\begin{array}{l}F=0.01, \\
P=0.9293\end{array}$ & $\begin{aligned} F & =60.94, \\
P & <0.0001\end{aligned}$ & $\begin{array}{l}F=2.10, \\
P=0.1472\end{array}$ & $\begin{array}{l}F=0.32, \\
P=0.5702\end{array}$ & $\begin{array}{l}F=11.54, \\
P=0.0007\end{array}$ & $\begin{array}{l}F=46.45, \\
P<0.0001\end{array}$ & $\begin{array}{l}F=0.27, \\
P=0.6014\end{array}$ \\
\hline
\end{tabular}




\begin{tabular}{|c|c|c|c|c|c|c|c|c|c|c|}
\hline & $\begin{array}{l}\text { Variable } \\
\text { (table 1) }\end{array}$ & RWBL & BWTE & MALL & AMCO & GADW & COYE & YHBL & NSHO & SAVS \\
\hline East & & $\begin{array}{l}F=2.39, \\
P=0.1225\end{array}$ & $\begin{array}{l}F=57.39 \\
P<0.0001\end{array}$ & $\begin{array}{l}F=17.44 \\
P<0.0001\end{array}$ & $\begin{array}{l}F=29.02 \\
P<0.0001\end{array}$ & $\begin{array}{c}F=88.62, \\
P<0.0001\end{array}$ & $\begin{array}{l}F=6.50, \\
P=0.0109\end{array}$ & $\begin{array}{l}F=0.18, \\
P=0.6692\end{array}$ & $\begin{array}{l}F=56.48, \\
P<0.0001\end{array}$ & $\begin{array}{l}F=0.00, \\
P=0.9818\end{array}$ \\
\hline North & & $\begin{array}{l}F=43.54 \\
P<0.0001\end{array}$ & $\begin{array}{l}F=70.01 \\
P<0.0001\end{array}$ & $\begin{array}{l}F=21.60 \\
P<0.0001\end{array}$ & $\begin{array}{l}F=0.23, \\
P=0.6327\end{array}$ & $\begin{array}{l}F=54.91 \\
P<0.0001\end{array}$ & $\begin{array}{l}F=9.24, \\
P=0.0024\end{array}$ & $\begin{array}{l}F=1.48, \\
P=0.2241\end{array}$ & $\begin{array}{l}F=3.50, \\
P=0.0614\end{array}$ & $\begin{aligned} F & =31.77, \\
P & <0.0001\end{aligned}$ \\
\hline
\end{tabular}



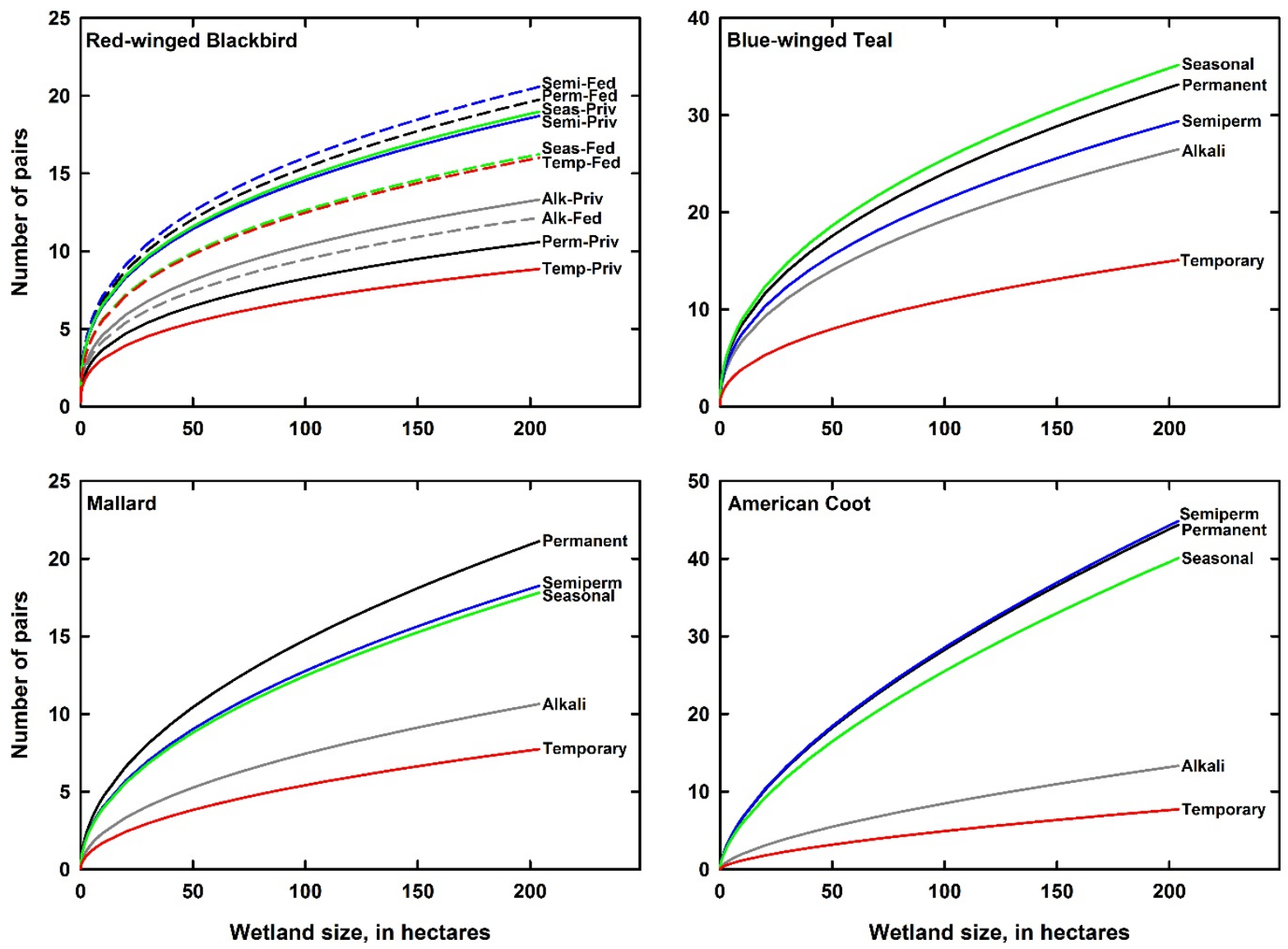

Figure 3. Plots of the number of breeding pairs compared to wetland size for each focal wetland bird species in the Prairie Pothole Region of North Dakota and South Dakota in 1995-97. Separate lines are graphed for each class, class-by-owner combination, or overall (if no class differences were detected in the analysis of covariance). For each line, Julian date, easting, and northing were held at their mean values, and intercepts were averaged across wetland types and owners (if not important). For overall lines for Gadwall and Savannah Sparrow, intercepts were averaged across all wetland classes, types, and owners. [Perm, Permanent; Semi or Semiperm, Semipermanent; Seas, Seasonal; Temp, Temporary; Alk, Alkali; Fed, Federal; Priv, Private]

Differences in the number of breeding pairs between natural and restored wetlands were detected for four of the nine species (tables 2 and 3; fig. 4). For three species (Gadwall, Common Yellowthroat, and Blue-winged Teal), the differences depended on wetland owner; however, for Blue-winged Teal, multiple comparisons between wetland types by ownership group indicated no differences between natural and restored wetlands for either private or Federal ownership. For Gadwall and Common Yellowthroat, the number of pairs observed on restored private wetlands was significantly greater than on natural private wetlands. For American Coot, number of pairs was significantly greater on natural wetlands than restored wetlands. 

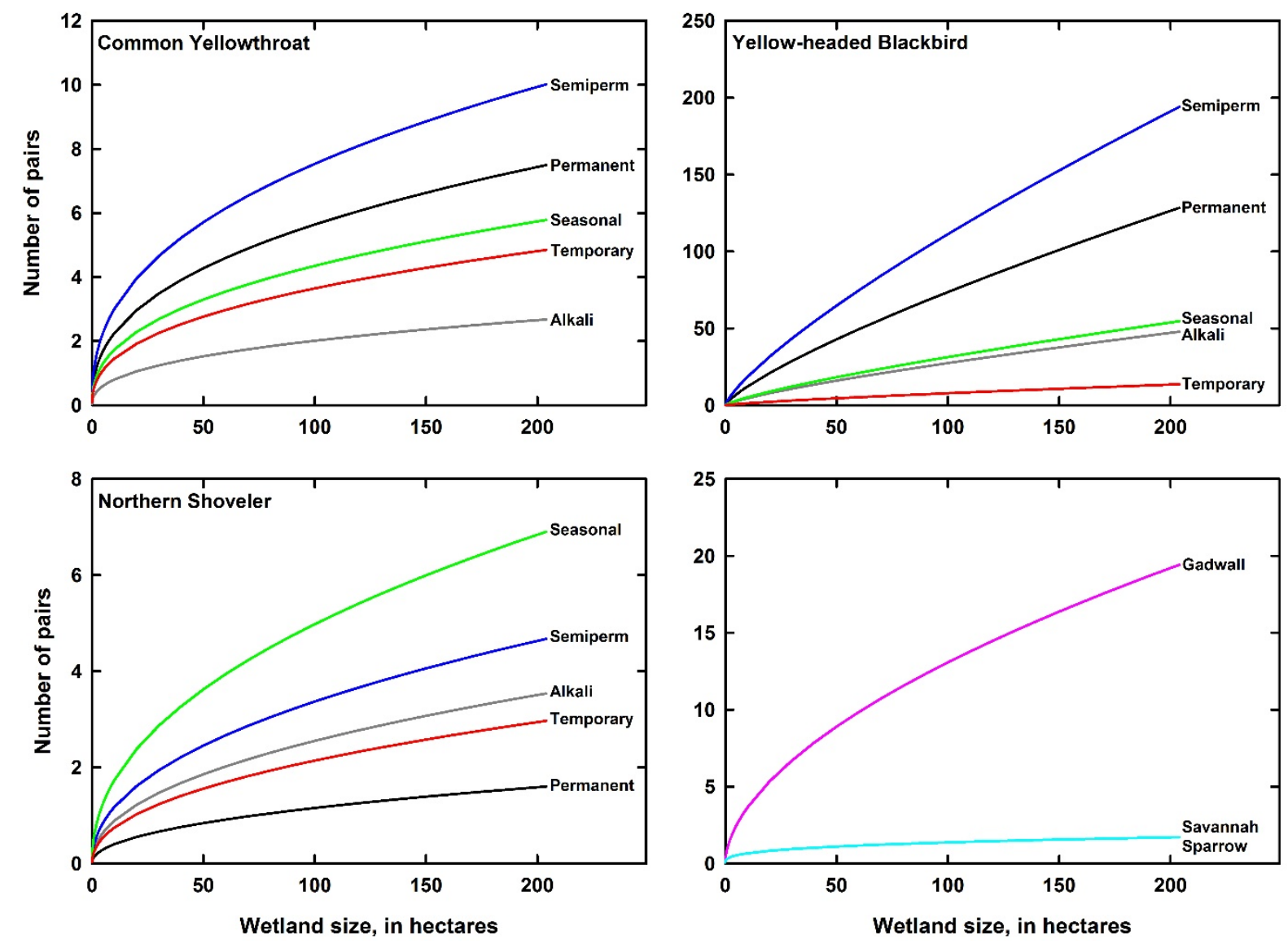

Figure 3. Plots of the number of breeding pairs compared to wetland size for each focal wetland bird species in the Prairie Pothole Region of North and South Dakota in 1995-97. Separate lines are graphed for each class, class-by-owner combination, or overall (if no class differences were detected in the analysis of covariance). For each line, Julian date, easting, and northing were held at their mean values, and intercepts were averaged across wetland types and owners (if not important). For overall lines for Gadwall and Savannah Sparrow, intercepts were averaged across all wetland classes, types, and owners. [Perm, Permanent; Semi or Semiperm, Semipermanent; Seas, Seasonal; Temp, Temporary; Alk, Alkali; Fed, Federal; Priv, Private]—Continued

For five of nine species, differences were detected between wetland owners (tables 2 and 3). The number of Northern Shoveler pairs was significantly greater for Federal wetlands than for private wetlands (fig. 4). For Red-winged Blackbird, differences in number of pairs between owners depended on the wetland class; numbers were significantly greater on Federal than on private land for temporary wetlands (fig. 3). For the remaining three species (Blue-winged Teal, Gadwall, and Common Yellowthroat), owner differences depended on wetland type (fig. 4). The number of pairs was significantly greater for Federal natural wetlands than for private natural wetlands for all three species. For Common Yellowthroat, private restored wetlands had significantly higher counts than Federal restored wetlands. 

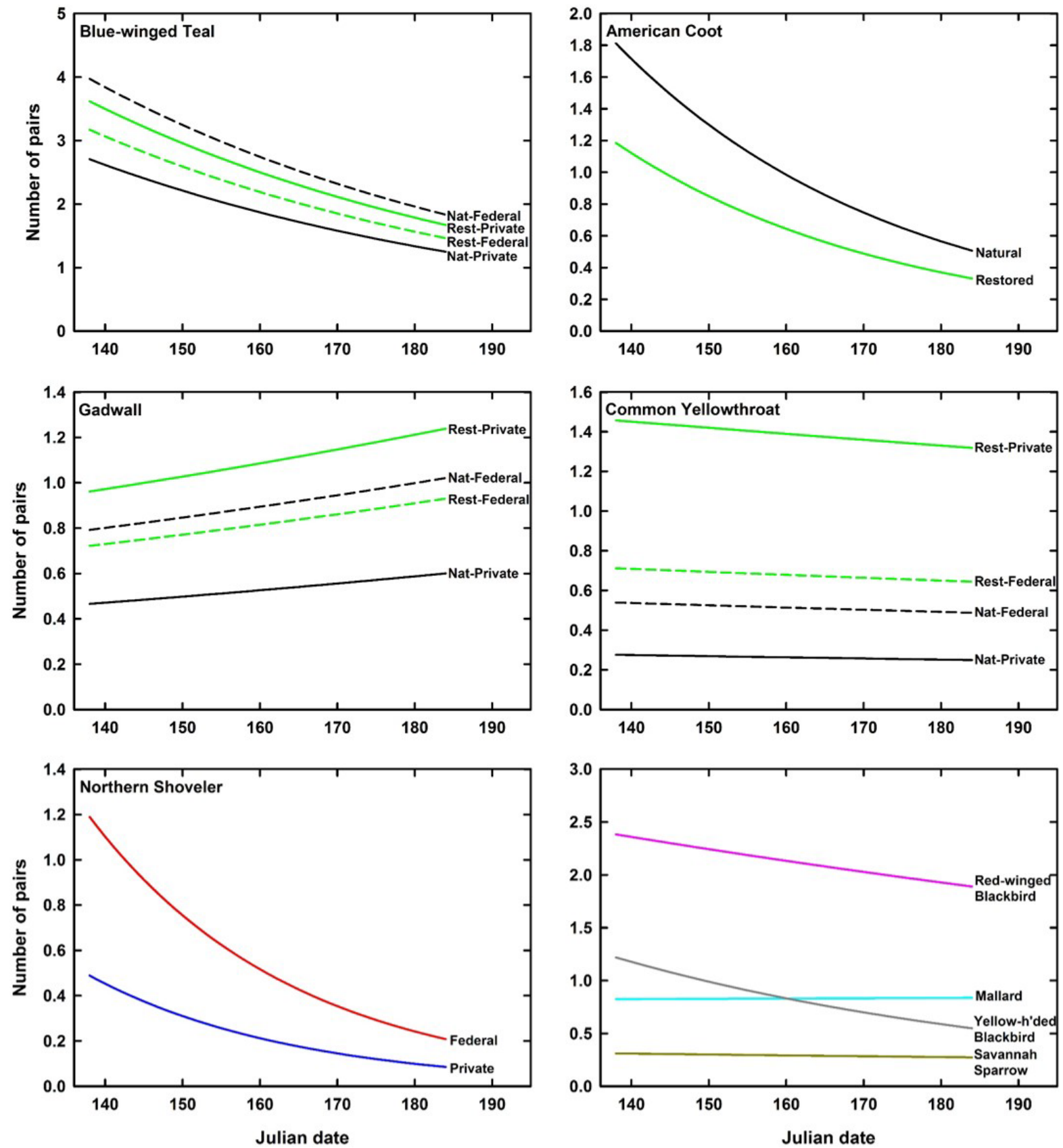

Figure 4. Plots of the number of pairs compared to Julian date for each wetland bird species in the Prairie Pothole Region of North and South Dakota in 1995-97. Separate lines are graphed for each wetland type, owner, type-by-owner, or overall (depending on results of the analysis of covariance). For each line, wetland size, easting, and northing were held at their mean values and intercepts were averaged across factors not included in plot. For overall lines for Mallard, Red-winged Blackbird, Yellow-headed Blackbird, and Savannah Sparrow, intercepts were averaged across all wetland classes, types, and owners. [Rest, Restored; Nat, Natural; h'ded, headed] 


\section{Influence of Wetland- and Landscape-Level Covariates}

For each species, plausible models $\left(\triangle A I C_{C}<4.0\right)$ are given in table 4 . For the Red-winged and Yellow-headed blackbirds, the percentage of the wetland in emergent vegetation $(E V)$ was included in every plausible model; the number of indicated breeding pairs was positively related to $E V$. In addition, the best model included the percentage of wetland area within $800 \mathrm{~m}$ (Wetland800) for the Red-winged Blackbird and the percentage of grassland area within $800 \mathrm{~m}$ (Grass800) for the Yellow-headed Blackbird; both variables were negatively related to the number of breeding pairs. The percentage of the wetland in open water $(O W)$ was included in every plausible model for the number of indicated breeding pairs of Blue-winged Teal, Mallard, American Coot, Gadwall, Common Yellowthroat, and Northern Shoveler-the relationships were positive for Blue-winged Teal, Mallard, American Coot, Gadwall, and Northern Shoveler, and negative for Common Yellowthroat. For Gadwall and Common Yellowthroat, the best models also included the number of wetlands within $800 \mathrm{~m}$ (Numwet800); these relationships were negative. For Blue-winged Teal, the best model included only $O W$, and for Mallard the best model included a positive relationship with Wetland800 and a negative relationship with Numwet800. The Grass800 was included in the best model for American Coot; the number of breeding pairs of coots was negatively related to Grass800. The best model for Northern Shoveler also included a positive relationship with Wetland800. For Savannah Sparrow, Grass800 was included in every plausible model; the number of pairs was positively related to Grass800. In addition, the best model included a positive relationship with $O W$. Pseudo- $R^{2}$ for all the best models ranged from 0.09 to 0.18 , indicating that the fit of these models was somewhat poor. Plots of predicted versus observed values also revealed that the fits of the models were poor and the models had low predictive power.

\section{Discussion}

Wetlands in the study area provided habitat for many species of birds during the breeding season in the Prairie Pothole Region of North and South Dakota (fig. 1). Over one-half of the 133 species are considered obligate wetland birds (depend on wetlands for their entire life cycle; for example, Pied-billed Grebe) or facultative wetland birds (use wetlands as part of a wider array of habitats; for example, Common Yellowthroat) (Grover and Baldassarre, 1995; Weller, 1999; Locky and others, 2005). Several of these wetland species (for example, Least and American bitterns, Western and Horned grebes [Aechmophorus occidentalis and Podiceps auritus, respectively], Franklin's Gull, and Black Tern) are designated as species of conservation concern in this region (Beyersbergen and others, 2004; USFWS, 2008; South Dakota Department of Game, Fish and Parks, 2014; Dyke and others, 2015). Species of conservation concern were found in all classes of wetlands, on private and Federal wetlands, and on natural and restored wetlands.

Several grassland bird species (for example, Bobolink [Dolichonyx oryzivorus] and Savannah Sparrow) also used wetland habitats in this study. Admittedly, there is considerable overlap between lists of facultative wetland birds (Grover and Baldassarre, 1995; Locky and others, 2005) and lists of facultative grassland birds (Vickery and others, 1999), which, in part, reflects the similarity in grass-like vegetation that is characteristic of both wetlands and grasslands (for example, Le Conte's Sparrow [Ammodramus leconteii] use of both wet meadow and upland grassland habitats in this region; Igl, 1999; Igl and Johnson, 1999). Wetlands, or their margins, also may be an important habitat for some grassland-breeding birds (for example, 
Table 4. Information-theoretic results for assessing effects of wetland and landscape variables on the number of breeding pairs of nine focal species ( $n=1,190$ wetlands) in the Prairie Pothole Region of North and South Dakota in 1995-97.

[Signs of the parameter estimates were included in parentheses for the continuous covariates. Best models $\left(\triangle A I C_{C}<4.0\right)$ are listed on top for each species. $k$, number of parameters. LL, $\log$ likelihood; $A I C_{C}$, Akaike's Information Criteria for small sample sizes; $\triangle A I C_{C}$, difference in $A I C_{C}$ from model with the lowest $A I C_{C} ; w$, Akaike weight (relative likelihood of each model); Pseudo- $R^{2}$, indication of model fit; Class, wetland class (alkali, permanent, semipermanent, seasonal, or temporary); Owner, landowner group (private or Federal); Lsize, log-transformed (natural logarithm) wetland size; (+), positive relationship; Juldate, Julian date of survey; (-), negative relationship; North, rescaled northing; EV, percentage of the wetland in emergent vegetation; Wetland800, percentage of wetland area within 800 meters; Numwet800, number of wetlands within 800 meters; Grass800, percentage of grassland area within 800 meters; Wtype, wetland type (natural or restored); East, rescaled easting; $O W$, percentage of the wetland in open water; WM, percentage of the wetland in wet meadow]

\begin{tabular}{|c|c|c|c|c|c|c|c|}
\hline Species & Plausible models & $k$ & LL & $A I C_{c}$ & $\Delta A I C_{c}$ & w & $\begin{array}{c}\text { Pseudo- } \\
R^{2}\end{array}$ \\
\hline \multirow{5}{*}{$\begin{array}{r}\text { Red-winged } \\
\text { Blackbird }\end{array}$} & Class*Owner, Lsize(+), Juldate(-), North(-), EV(+), Wetland800(-) & 16 & $-2,407.58$ & 4,847.63 & 0.000 & 0.396 & 0.13 \\
\hline & Class*Owner, Lsize(+), Juldate(-), North(-), EV(+) & 15 & $-2,409.13$ & $4,848.68$ & 1.049 & 0.234 & 0.13 \\
\hline & $\begin{array}{l}\text { Class*Owner, Lsize(+), Juldate(-), North(-), EV(+), Wetland800(-), } \\
\text { Numwet800(-) }\end{array}$ & 17 & $-2,407.49$ & $4,849.51$ & 1.881 & 0.154 & 0.13 \\
\hline & Class*Owner, Lsize(+), Juldate(-), North(-), EV(+), Numwet800(-) & 16 & $-2,409.05$ & $4,850.56$ & 2.929 & 0.091 & 0.13 \\
\hline & Class*Owner, Lsize(+), Juldate(-), North(-), EV(+), Grass800(-) & 16 & $-2,409.09$ & $4,850.64$ & 3.016 & 0.088 & 0.13 \\
\hline \multirow{6}{*}{ Blue-winged Teal } & Class, Wtype*Owner, Lsize(+), Juldate(-), East(-), North(-), OW(+) & 15 & $-2,410.83$ & $4,850.01$ & 0.000 & 0.302 & 0.14 \\
\hline & $\begin{array}{l}\text { Class, Wtype*Owner, Lsize(+), Juldate(-), East(-), North(-), OW(+), } \\
\text { Wetland800(+) }\end{array}$ & 16 & $-2,409.83$ & $4,850.07$ & 0.064 & 0.292 & 0.14 \\
\hline & $\begin{array}{l}\text { Class, Wtype*Owner, Lsize(+), Juldate(-), East(-), North(-), OW(+), } \\
\quad \text { Numwet } 800(-)\end{array}$ & 16 & $-2,410.64$ & $4,851.70$ & 1.688 & 0.130 & 0.14 \\
\hline & $\begin{array}{l}\text { Class, Wtype*Owner, Lsize(+), Juldate(-), East(-), North(-), OW(+), } \\
\text { Wetland800(+) Numwet800(-) }\end{array}$ & 17 & $-2,409.70$ & $4,851.87$ & 1.865 & 0.119 & 0.14 \\
\hline & $\begin{array}{l}\text { Class, Wtype*Owner, Lsize(+), Juldate(-), East(-), North(-), OW(+), } \\
\text { Grass800(-) }\end{array}$ & 16 & $-2,410.81$ & $4,852.02$ & 2.011 & 0.110 & 0.14 \\
\hline & $\begin{array}{l}\text { Class, Wtype*Owner, Lsize(+), Juldate(-), East(-), North(-), OW(+), } \\
\text { Grass800(-), Numwet800(-) }\end{array}$ & 17 & $-2,410.64$ & $4,853.74$ & 3.736 & 0.047 & 0.14 \\
\hline \multirow{2}{*}{ Mallard } & $\begin{array}{l}\text { Class, Lsize(+), East(-), North(-), OW(+), Wetland800(+), } \\
\quad \text { Numwet800(-) }\end{array}$ & 12 & $-1,718.25$ & $3,460.76$ & 0.000 & 0.545 & 0.13 \\
\hline & Class, Lsize(+), East(-), North(-), OW(+), Numwet800(-) & 11 & $-1,719.93$ & $3,462.08$ & 1.312 & 0.283 & 0.13 \\
\hline
\end{tabular}




\begin{tabular}{|c|c|c|c|c|c|c|c|}
\hline Species & Plausible models & $k$ & LL & $A I C_{C}$ & $\Delta A I C_{C}$ & $w$ & $\begin{array}{c}\text { Pseudo- } \\
R^{2}\end{array}$ \\
\hline & $\begin{array}{l}\text { Class, Lsize(+), East(-), North(-), OW(+), Grass800(+), } \\
\quad \text { Numwet800(-) }\end{array}$ & 12 & $-1,719.91$ & $3,464.09$ & 3.329 & 0.103 & 0.13 \\
\hline \multirow{3}{*}{ American Coot } & Class, Wtype, Lsize(+), Juldate(-), East(-), OW(+), Grass800(-) & 13 & $-1,830.36$ & 3,684.99 & 0.000 & 0.578 & 0.18 \\
\hline & $\begin{array}{l}\text { Class, Wtype, Lsize(+), Juldate(-), East(-), OW(+), Grass800(-), } \\
\text { Numwet800(+) }\end{array}$ & 14 & $-1,830.34$ & $3,687.00$ & 2.012 & 0.211 & 0.18 \\
\hline & Class, Wtype, Lsize(+), Juldate(-), East(-), OW(+) & 12 & $-1,833.03$ & $3,688.29$ & 3.300 & 0.111 & 0.18 \\
\hline \multirow{4}{*}{ Gadwall } & Wtype*Owner, Lsize(+), East(-), North(-), OW(+), Numwet800(-) & 10 & $-1,593.52$ & $3,207.22$ & 0.000 & 0.488 & 0.18 \\
\hline & $\begin{array}{l}\text { Wtype*Owner, Lsize }(+), \text { East }(-), \text { North }(-), \text { OW(+), Grass800(+), } \\
\text { Numwet800(-) }\end{array}$ & 11 & $-1,593.51$ & $3,209.24$ & 2.015 & 0.178 & 0.18 \\
\hline & $\begin{array}{l}\text { Wtype*Owner, Lsize }(+), \text { East(-), North }(-), \text { OW(+), Wetland800(-), } \\
\quad \text { Numwet800(-) }\end{array}$ & 11 & $-1,593.52$ & $3,209.26$ & 2.035 & 0.176 & 0.18 \\
\hline & Wtype*Owner, Lsize(+), East(-), North(-), OW(+) & 9 & $-1,596.24$ & $3,210.63$ & 3.407 & 0.089 & 0.18 \\
\hline \multirow{3}{*}{$\begin{array}{l}\text { Common } \\
\text { Yellowthroat }\end{array}$} & $\begin{array}{l}\text { Class, Wtype*Owner, Lsize(+), East(+), North(-), OW(-), } \\
\text { Numwet800(-) }\end{array}$ & 15 & $-1,483.84$ & 2,996.04 & 0.000 & 0.530 & 0.12 \\
\hline & $\begin{array}{l}\text { Class, Wtype*Owner, Lsize(+), East(+), North(-), OW(-), } \\
\quad \text { Grass } 800(+), \text { Numwet800(-) }\end{array}$ & 16 & $-1,483.77$ & $2,997.95$ & 1.915 & 0.203 & 0.12 \\
\hline & $\begin{array}{l}\text { Class, Wtype*Owner, Lsize(+), East(+), North(-), OW(-), } \\
\text { Wetland800(-), Numwet800(-) }\end{array}$ & 16 & $-1,483.81$ & $2,998.02$ & 1.985 & 0.196 & 0.12 \\
\hline \multirow{2}{*}{$\begin{array}{l}\text { Yellow-headed } \\
\text { Blackbird }\end{array}$} & Class, Lsize(+), Juldate(-), EV(+), Grass800(-) & 10 & $-1,874.71$ & $3,769.60$ & 0.000 & 0.583 & 0.15 \\
\hline & Class, Lsize(+), Juldate(-), EV(+), Grass800(-), Numwet800(-) & 11 & $-1,874.03$ & $3,770.29$ & 0.687 & 0.413 & 0.15 \\
\hline \multirow{6}{*}{ Northern Shoveler } & Class, Owner, Lsize(+), Juldate(-), East(-), OW(+), Wetland800(+) & 13 & $-1,063.35$ & $2,150.97$ & 0.000 & 0.268 & 0.14 \\
\hline & Class, Owner, Lsize(+), Juldate(-), East(-), OW(+), Grass800(-) & 13 & $-1,063.55$ & 2,151.36 & 0.386 & 0.221 & 0.14 \\
\hline & $\begin{array}{l}\text { Class, Owner, Lsize(+), Juldate(-), East(-), OW(+), Wetland800(+), } \\
\quad \text { Numwet800(-) }\end{array}$ & 14 & $-1,062.72$ & $2,151.75$ & 0.780 & 0.182 & 0.14 \\
\hline & $\begin{array}{l}\text { Class, Owner, Lsize(+), Juldate(-), East(-), OW(+), Grass800(-), } \\
\quad \text { Numwet800(-) }\end{array}$ & 14 & $-1,063.07$ & $2,152.45$ & 1.485 & 0.128 & 0.14 \\
\hline & Class, Owner, Lsize(+), Juldate(-), East(-), OW(+) & 12 & $-1,065.33$ & $2,152.88$ & 1.907 & 0.103 & 0.14 \\
\hline & Class, Owner, Lsize(+), Juldate(-), East(-), OW(+), Numwet800(-) & 13 & $-1,064.44$ & 2,153.14 & 2.168 & 0.091 & 0.14 \\
\hline
\end{tabular}




\begin{tabular}{|c|c|c|c|c|c|c|c|}
\hline Species & Plausible models & $k$ & LL & $A I C_{c}$ & $\Delta A I C_{c}$ & $w$ & $\begin{array}{c}\text { Pseudo- } \\
R^{2} \\
\end{array}$ \\
\hline \multirow{6}{*}{ Savannah Sparrow } & Lsize(+), North(+), OW(+), Grass800(+) & 5 & -950.771 & $1,913.61$ & 0.000 & 0.310 & 0.09 \\
\hline & Lsize(+), North(+), Grass800(+) & 4 & -951.840 & $1,913.73$ & 0.116 & 0.292 & 0.08 \\
\hline & Lsize(+), North(+), OW(+), Grass800(+), Numwet800(-) & 6 & -950.648 & $1,915.39$ & 1.776 & 0.127 & 0.09 \\
\hline & Lsize(+), North(+), Grass800(+), Numwet800(-) & 5 & -951.752 & $1,915.57$ & 1.961 & 0.116 & 0.08 \\
\hline & Lsize(+), North(+), WM(+), Grass800(+) & 5 & -951.832 & $1,915.73$ & 2.120 & 0.107 & 0.08 \\
\hline & Lsize(+), North(+), WM(+), Grass800(+), Numwet800(-) & 6 & -951.747 & $1,917.59$ & 3.976 & 0.042 & 0.08 \\
\hline
\end{tabular}


Bobolink) in semiarid regions or during dry periods (Hubbard, 1982; Peterjohn and Sauer, 1999; Igl and others, 2008). In the northern Great Plains, Niemuth and others (in press) found that the occurrence of Bobolinks and Savannah Sparrows was positively associated with the area of emergent herbaceous wetlands within the surrounding landscape (that is, areas where herbaceous vegetation accounts for greater than 80 percent of vegetative cover and the soil or substrate is periodically saturated with water), which is consistent with their selection for mesic grasslands.

Climatic variation is considered a primary driver of water conditions in the Prairie Pothole Region (van der Valk, 2005; Niemuth and others, 2010). Wetland area and water levels and regimes in the Prairie Pothole Region are dynamic over time, resulting in high interannual variation in aquatic vegetation (Kantrud and others, 1989b; Euliss and others, 2004) and persistence of water within wetlands (van der Valk, 2005; Niemuth and others, 2010; Harold A. Kantrud, oral commun.). Our study occurred during a period of deluge in the northern Great Plains (Williams-Sether and others, 1994; Williams-Sether, 1999; Winter and Rosenberry, 1998; Niemuth and others, 2010). High water during a deluge period typically is characterized by a turnover in plant populations, greater interspersion of emergent cover and open water, but lower overall productivity (Johnson and others, 2005); thus, inferences drawn from results from this study may be potentially limited to years with high precipitation and greater wetland availability.

Wetlands in this region follow a gradient of water permanency: temporary wetlands generally have the least amount of water and the most variability from 1 year to the next, whereas permanent wetlands have the greatest area and the least variability among years (Stewart and Kantrud, 1971; Niemuth and others, 2010). Wetland classification for an individual wetland in this region may vary among years because of fluctuations in water levels and water conditions; for example, a semipermanent wetland may be classified as a seasonal wetland during a dry period, and a temporary wetland may be classified as a seasonal wetland during a wet period (Niemuth and others, 2010; Harold A. Kantrud, oral commun.). In this study, focal wetlands were classified at the time of the bird surveys, and thus wetland classification of an individual wetland was not necessarily static across years.

Wetland classes differed in their potential to provide habitat for different wetland bird species. We observed 76 species of birds in 165 temporary wetlands, 102 species in 410 seasonal wetlands, 109 species in 524 semipermanent wetlands, 96 species in 47 permanent wetlands, and 87 species in 44 alkali wetlands. For seven of the nine focal species in this study, abundances differed among wetland classes; for example, the Blue-winged Teal was less abundant on temporary wetlands than all other wetland classes and was significantly more abundant on seasonal than on semipermanent wetlands; Stewart and Kantrud (1973) and Kantrud and Stewart (1977) found similar results in North Dakota. In contrast, the American Coot was less abundant on alkali and temporary wetlands than on permanent, semipermanent, and seasonal wetlands, a result that also was shared by Kantrud and Stewart (1984). These contrasting results among species emphasize the ecological value of having a diversity of wetland classes in this region, including those that are generally smaller and shallower (that is, temporary and seasonal wetlands) and thus are most vulnerable to drainage (Niemuth and others, 2010).

We recorded 113 bird species on 610 private wetlands and 123 species on 580 Federal wetlands. Five of the nine focal species had higher abundances on Federal than on private wetlands. The Common Yellowthroat was the only species that had higher abundances on private wetlands than on Federal wetlands, but this was only observed for restored wetlands. For Redwinged Blackbird, differences in abundances between wetland owners depended on the wetland class; private temporary wetlands had fewer Red-winged Blackbird pairs than Federal temporary 
wetlands. These species-specific results defy a simple ecological explanation, and further research is needed to address questions related to differences in wetland bird abundance between public and private lands. Although land management on private and public lands differ and are mostly independent of each other, the matrix of private land surrounding public land can affect wildlife populations occupying public lands and vice versa (Petit and others, 1995). Nonetheless, these results highlight the importance of protected public lands for wetland birds, and also emphasize that the conservation of wetland birds in the Prairie Pothole Region will depend on conservation efforts on both private and public lands. The extent of private lands in this region (Cowardin and others, 1995; Cunningham, 2005) and the United States (Ciuzio and others, 2013) far surpasses that of public lands. Over 90 percent of land in the Prairie Pothole Region is in private ownership (Cowardin and others, 1995). The loss of wetlands on private lands continues. Between 1997 and 2009, the total wetland area in the Prairie Pothole Region declined by over 30,000 ha or 1.1 percent, and the total number of wetlands declined by 4 percent (Dahl, 2014). In total, 96 percent of the wetlands lost were temporarily flooded emergent and farmed wetlands (mean size of 0.3 ha). Between 2008 and 2012, 12,555 ha of wetlands were lost in North and South Dakota because of conversion to agriculture (Lark and others, 2015). Bird conservation in the United States will increasingly rely on State and Federal agencies to allocate resources for bird conservation programs on private lands (Ciuzio and others, 2013).

Our study occurred during a period of numerous wetland restorations in the Prairie Pothole Region. Since the mid-1980s, wetland restoration has become an important tool for natural resource managers for mitigating losses of natural wetlands that had been drained on private or public lands in the Prairie Pothole Region (Galatowitsch and van der Valk, 1994, 1996; Fairbairn and Dinsmore, 2001; Ratti and others, 2001). These restoration efforts, in part, were spurred by the implementation of the North American Waterfowl Management Plan and the initiation of the Conservation Reserve Program in the 1985 Food Security Act (Galatowitsch and van der Valk, 1994). We recorded 105 species in 426 restored wetlands and 124 species in 764 natural wetlands. American Coot had higher abundances on natural wetlands than on restored wetlands, and Gadwall and Common Yellowthroat had higher abundances on restored private wetlands than on natural private wetlands. Ratti and others (2001) also reported higher abundances on restored wetlands than natural wetlands in North and South Dakota for 4 of 14 wetland-dependent bird species; they also reported higher abundances of American Coots, Common Yellowthroats, and Gadwalls on restored wetlands than natural wetlands, but their results were nonsignificant. Ratti and others (2001) speculated that these differences in abundance may reflect an attraction to higher aquatic productivity in these regenerating restored wetlands.

Many studies have compared breeding bird species richness, abundance, diversity, and community composition in restored and natural wetlands in the Prairie Pothole Region (LaGrange and Dinsmore, 1989; Sewell and Higgins, 1991; Delphey and Dinsmore, 1993; Hemesath and Dinsmore, 1993; Schreiber, 1994; Schafer, 1996; VanRees-Siewert and Dinsmore, 1996; Dault, 2001; Ratti and others, 2001) and elsewhere in the United States (Hartman, 1994; Brown and Smith, 1998; Muir Hotaling and others, 2002). As with our study, previous research has indicated that restored wetlands are providing valuable habitat for many species of birds during the breeding season, which emphasizes the value of efforts to restore wetlands in this region (Ratti and others, 2001); however, Galatowitsch and van der Valk $(1994,1996)$ cautioned that, although plant or bird communities of restored wetlands may resemble those of natural wetlands as successional changes occur with age (for example, VanRees-Siewert and Dinsmore, 
1996; Fairbairn and Dinsmore, 2001), restored wetlands with only some of the characteristics of natural wetlands should not be considered comparable to natural wetlands in function. Moreover, we did not assess the age of the wetland restorations, which has been shown to affect the level of bird use in restored wetlands (VanRees-Siewert and Dinsmore, 1996; Muri Hotaling and others, 2002).

In the ANCOVA, we found a consistent positive relationship between the number of breeding pairs and wetland size for all nine focal species, indicating that the abundance of these species increased with the size of the wetland. Other studies have found that bird abundance increases with wetland size during the breeding season (Cowardin and others, 1995; Benoit and Askins, 2002; González-Gajardo and others, 2009; Sebastián-González and Green, 2014) and nonbreeding season (Webb and others, 2010). Several mechanisms have been proposed to explain why abundance is higher in larger wetlands, including greater habitat diversity, invertebrate food availability, and area for home range or territory-size requirements (Tozer and others, 2010). This relationship, however, does not negate the ecological value of numerous small wetlands located collectively in the landscape of the Prairie Pothole Region. Indeed, most of the wetlands in our study were small (that is, 2 ha or smaller). Small wetlands are critical for maintaining regional diversity, ecological connection, and source-sink dynamics of species populations (Semlitsch and Bodie, 1998). Several studies have emphasized the importance of small, temporary wetlands for migrating and breeding wetland birds (for example, Gibbs, 1993; Naugle and others, 2000b); moreover, some species require both small and large wetlands at different points in their life history (for example, some waterfowl; Yerkes, 2000), and thus maintaining a variety of wetland sizes and classes on the landscape may be required to satisfy the needs of those species (Adamus, 2013).

After adjusting for wetland size, and the date and location of the surveys, our results demonstrate that incorporating both wetland- and landscape-level factors in models can improve our ability to predict abundances of wetland birds in the Prairie Pothole Region. The top model for eight of the nine focal species included both wetland- and landscape-level factors, whereas the best model for the Blue-winged Teal included only wetland-level factors; for example, in our study, the abundance of Red-winged and Yellow-headed blackbirds (both of which build nests in cattails and other emergent vegetation) had a positive relationship with the percentage of the wetland in emergent vegetation, a result that was supported by Fairbairn and Dinsmore (2001) and Naugle and others (2000b). However, the abundance of Red-winged Blackbird (a facultative wetland species that also nests in uplands) declined with the amount of wetlands in the landscape, whereas the abundance of the Yellow-headed Blackbird (an obligate wetland species that only nests in wetlands) declined in wetlands as the amount of grassland in the landscape increased. Many other studies have demonstrated the importance of both local- and landscapelevel factors on bird communities (for example, Naugle and others, 2000a; Cunningham and Johnson, 2006; Tsai, 2007; Niemuth and others, 2008; Clough and others, 2009; Roselli and Stiles, 2012; Labbe and King, 2014; Galitsky and Lawler, 2015).

In this study, we recorded 133 species in a variety of wetland classes, types, and owners over a broad study area. Meeting the different habitat requirements of all wetland bird species and other wetland fauna in the Prairie Pothole Region will be challenging. As with other studies, our results reinforce the argument that wetland conservation and restoration will be most effective when considering the habitat characteristics at both the wetland scale and landscape scale (that is, considering habitat at multiple scales). Results from this study and others also emphasize the importance of wetland-grassland complexes (that is, clusters of wetlands of 
various permanence levels embedded in a grassland landscape) to meet the habitat needs of individual species (for example, Black Tern; Naugle and others, 2000a) and ensure that suitable habitat is available for all wetland breeding birds (Gleason and others, 2011). Admittedly, the fit of our models was weak, indicating that the models have low predictive power and that our knowledge of wetland bird ecology in this region is incomplete. Other factors (for example, those that we did not measure or those associated with migration or on the wintering grounds) also are likely important in explaining wetland bird abundance in this region. Identifying and quantifying these other variables is critical for the conservation of wetland birds in this region.

\section{References Cited}

Adamus, P., 2013, Wetland functions-Not only about size: National Wetlands Newsletter, v. 35, p. 18-19, 25.

American Ornithologists’ Union, 1998, Check-list of North American birds (7th ed.):

Washington, D.C., American Ornithologists’ Union, 877 p. [Also available at http://www.americanornithology.org/content/checklist-north-and-middle-american-birds.]

Baldassarre, G.A., and Bolen, E.G., 2006, Waterfowl ecology and management: Malabar, Fla., Krieger Publishing Company, 567 p.

Batt, B.D., Anderson, M.G., Anderson, C.D., and Caswell, F.D., 1989, Use of prairie potholes by North American ducks, in van der Valk, A., ed., Northern prairie wetlands: Ames, Iowa, Iowa State University Press, p. 204-227.

Benoit, L.K., and Askins, R.A., 2002, Relationship between habitat area and the distribution of tidal marsh birds: Wilson Bulletin, v. 114, no. 3, p. 314-333. [Also available at http://www.jstor.org/stable/4164466.]

Beyersbergen, G.W., Niemuth, N.D., and Norton, M.R., 2004, Northern prairie and parkland waterbird conservation plan: Denver, Colo., Prairie Pothole Joint Venture, accessed January 20, 2017 at https://www.fws.gov/mountain-

prairie/refuges/hapetResources/updatedFiles/publications/Beyersbergen.et.al.2004.waterbird.pl an.PPJV.pdf.

Bluemle, J.P., 2000, The face of North Dakota (3d ed.): Bismarck, N. Dak., North Dakota Geological Survey, Educational Series 21, 210 p.

Browder, S.F., Johnson, D.H., and Ball, I.J., 2002, Assemblages of breeding birds as indicators of grassland condition: Ecological Indicators, v. 2, no. 3, p. 257-270. [Also available at https://doi.org/10.1016/S1470-160X(02)00060-2.]

Brown, S.C., and Smith, C.R., 1998, Breeding season bird use of recently restored versus natural wetlands in New York: Journal of Wildlife Management, v. 62, no. 4, p. 1480-1491. [Also available at http://www.jstor.org/stable/3802014.]

Burnham, K.P., and Anderson, D.R., 2002, Model selection and multimodel inference-A practical information-theoretic approach (2d ed.): New York, Springer-Verlag, 488 p.

Ciuzio, E., Hohman, W.S., Martin, B., Smith, M.D., Stephens, S., Strong, A.M., and Vercauteren, T., 2013, Opportunities and challenges to implementing bird conservation on private lands: Wildlife Society Bulletin, v. 37, no. 2, p. 267-277. [Also available at https://doi.org/10.1002/wsb.266.]

Clough, Yann, Putra, D.D., Pitopang, R., and Tscharntke, T., 2009, Local and landscape factors determine function in bird diversity in Indonesian cacao agroforestry: Biological Conservation, v. 142, no. 5, p. 1032-1041. [Also available at https://doi.org/10.1016/j.biocon.2008.12.027.] 
Cowardin, L.M., Carter, V., Golet, F.C., and LaRoe, E.T., 1979, Classification of wetlands and deepwater habitats of the United States: Washington, D.C., U.S. Fish and Wildlife Service, FWS/OBS/79/31, 131 p.

Cowardin, L.M., Shaffer, T.L., and Arnold, P.M., 1995, Evaluations of duck habitat and estimation of duck population sizes with a remote-sensing-based system: Washington, D.C., U.S. Department of the Interior, National Biological Service, Biological Science Report 2, 26 p.

Cunningham, M.A., 2005, A comparison of public lands and farmlands for grassland bird conservation: Professional Geographer, v. 57, no. 1, p. 51-65. [Also available at https://doi.org/10.1111/j.0033-0124.2005.00459.x.]

Cunningham, M.A., and Johnson, D.H., 2006, Proximate and landscape factors influence grassland bird distributions: Ecological Applications, v. 16, no. 3, p. 1062-1075.

Dahl, T.E., 2014, Status and trends of prairie wetlands in the United States 1997 to 2009: Washington, D.C., U.S. Department of the Interior, Fish and Wildlife Service, Ecological Services, 67 p., accessed January 20, 2017 at https://www.fws.gov/wetlands/Documents/Status-and-Trends-of-Prairie-Wetlands-in-theUnited-States-1997-to-2009.pdf.

Dault, R.E., 2001, Long-term effects of wetland restoration on bird communities in the Prairie Pothole Region of northwestern Iowa: Ames, Iowa, Iowa State University, Master's Thesis, $107 \mathrm{p}$.

Delphey, P.J., and Dinsmore, J.J., 1993, Breeding bird communities of recently restored and natural prairie potholes: Wetlands, v. 13, no. 3, p. 200-206. [Also available at https://doi.org/10.1007/BF03160881.]

Doherty, K.E., Ryba, A.J., Stemler, C.L., Niemuth, N.D., and Meeks, W.A., 2013, Conservation planning in an era of change-State of the U.S. Prairie Pothole Region: Wildlife Society Bulletin, v. 37, no. 3, p. 546-563. [Also available at https://doi.org/10.1002/wsb.284.]

Dyke, S.R., Johnson, S.K., and Isakson, P.T., 2015. North Dakota State wildlife action plan: Bismarck, N. Dak., North Dakota Game and Fish Department, accessed January 20, 2017 at https://gf.nd.gov/sites/default/files/publications/swap-2015_0.pdf.

Euliss, N.H., J. W. LaBaugh, J.W., Fredrickson, L.H., Mushet, D.M., Laubhan, M.K., Swanson, G.A., Winter, T.C., Rosenberry, D.O., and Nelson, R.D., 2004, The wetland continuum-A conceptual framework for interpreting biological studies: Wetlands, v. 24, no. 2, p. 448-458. [Also available at https://doi.org/10.1672/0277-5212(2004)024[0448:TWCACF]2.0.CO;2.]

Fairbairn, S.E., and Dinsmore, J.J., 2001, Local and landscape-level influences on wetland bird communities of the Prairie Pothole Region of Iowa, USA: Wetlands, v. 21, no. 1, p. 41-47. [Also available at https://doi.org/10.1672/0277-5212(2001)021[0041:LALLIO]2.0.CO;2.]

Galatowitsch, S.M., and van der Valk, A.G., 1994. Restoring prairie wetlands: an ecological approach: Ames, Iowa, Iowa State University Press, 246 p.

Galatowitsch, S.M., and van der Valk, A.G., 1996, Characteristics of recently restored wetlands in the Prairie Pothole Region: Wetlands, v. 16, no. 1, p. 75-83. [Also available at https://doi.org/10.1007/BF03160647.]

Galitsky, C., and Lawler, J.J., 2015, Relative influence of local and landscape factors on bird communities vary by species and functional group: Landscape Ecology, v. 30, no. 2, p. 287299. [Also available at https://doi.org/10.1007/s10980-014-0138-4.] 
Gibbs, J.P., 1993, The importance of small wetlands for the persistence of local populations of wetland-associated animals: Wetlands, v. 13, no. 1, p. 25-31. [Also available at https://doi.org/10.1007/BF03160862.]

Gibbs, J.P., and Melvin, S.M., 1993, Call-response survey for monitoring breeding waterbirds: Journal of Wildlife Management, v. 57, no. 1, p. 27-34. [Also available at https://doi.org/10.2307/3808996.]

Gleason, R.A., Euliss, Jr., N.H., Tangen, B.A., Laubhan, M.K., and Browne, B.A., 2011, USDA conservation program and practice effects on wetland ecosystem services in the Prairie Pothole Region: Ecological Applications, v. 21, no. sp1, p. S65-S81. [Also available at https://doi.org/10.1890/09-0216.1.]

Gleason, R.A., Laubhan, M.K., and Euliss, N.H., Jr., 2008, Ecosystem services derived from wetland conservation practices in the United States Prairie Pothole Region with an emphasis on the U.S. Department of Agriculture Conservation Reserve and Wetlands Reserve Programs: U.S. Geological Survey Professional Paper 1745, 58 p., accessed March 30, 2017 at https://pubs.usgs.gov/pp/1745/.

González-Gajardo, A., Sepúlveda, P.V., and Schlatter, R., 2009, Waterbird assemblages and habitat characteristics in wetlands-Influence of temporal variability on species-habitat relationships: Waterbirds, v. 32, no. 2, p. 225-233. [Also available at https://doi.org/10.1675/063.032.0203.]

Grover, A.M., and Baldassarre, G.A., 1995, Bird species richness within beaver ponds in southcentral New York: Wetlands, v. 15, no. 2, p. 108-118. [Also available at https://doi.org/10.1007/BF03160664.]

Hammond, M.C., 1969, Notes on conducting waterfowl breeding population surveys in the north central states, in Saskatoon Wetlands Seminar: Saskatoon, Saskatchewan, Canadian Wildlife Service, Report Series No. 6, p. 238-254.

Hartman, M.R., 1994, Avian use of restored and natural wetlands in north-central Indiana: West Lafayette, Ind., Purdue University, Master’s Thesis, 98 p.

Hemesath, L.M., and Dinsmore, J.J., 1993, Factors affecting bird colonization of restored wetlands: Prairie Naturalist, v. 25, no. 1, p. 1-11.

Higgins, K.F., Naugle, D.E., and Forman, K.J., 2002, A case study of changing land use practices in the northern Great Plains, U.S.A.-An uncertain future for waterbird conservation: Waterbirds, v. 25, special publication 2, p. 42-50. [Also available at http://www.jstor.org/stable/1522450.]

Hilbe, J.M., 2011, Negative binomial regression (2d ed.): New York, Cambridge University Press, $553 \mathrm{p}$.

Hoekstra, J.M., Boucher, T.M., Ricketts, T.H., and Roberts, C., 2005, Confronting a biome crisis: global disparities of habitat loss and protection: Ecology Letters, v. 8, no. 1, p. 23-29. [Also available at https://doi.org/10.1111/j.1461-0248.2004.00686.x.]

Hubbard, D.E., 1982, Breeding birds in 2 dry wetlands in eastern South Dakota: Prairie Naturalist, v. 14, no. 1, p. 6-8.

Igl, L.D., 1999, Le Conte’s Sparrow-Ephemeral jewel of the northern Great Plains: North Dakota Outdoors, v. 61, no. 8, p. 10-13.

Igl, L.D., 2004, A probable extralimital post-breeding assembly of Bufflehead Bucephala albeola in southcentral North Dakota, USA, 1994-2002: Wildfowl, v. 54, p. 81-93. 
Igl, L.D., and Johnson, D.H., 1997, Changes in breeding bird populations in North Dakota1967 to 1992-93: Auk, v. 114, no. 1, p. 74-92. [Also available at https://doi.org/10.2307/4089067.]

Igl, L.D., and Johnson, D.H., 1999, Le Conte’s Sparrows breeding in Conservation Reserve Program fields-Precipitation and patterns of population change: Studies in Avian Biology, v. 19, p. 178-186.

Igl, L.D., Johnson, D.H., and Kantrud, H.A., 2008, A historical perspective: changes in grassland breeding bird densities within major habitats in North Dakota between 1967 and 1992-1993: Proceedings of the North American Prairie Conference, v. 20, p. 275-295.

Igl, L.D., Shaffer, J.A., Johnson, D.H., and Buhl, D.A., 2017, The influence of local- and landscape-level factors on wetland breeding birds in the Prairie Pothole Region of North and South Dakota dataset: U.S. Geological Survey data release, https://doi.org/10.5066/F7FX77XM.

Johnson, D.H., and Batie, R.D., 2001, Surveys of calling amphibians in North Dakota: Prairie Naturalist, v. 33, no. 4, p. 227-247.

Johnson, R.R., and Higgins, K.F., 1997, Wetland resources of eastern South Dakota: Brookings, S. Dak., South Dakota State University, U.S. Geological Survey Cooperative Fish and Wildlife Research Unit, 102 p., accessed January 20, 2017, at https://www.fws.gov/wetlands/Documents/Wetland-Resources-of-Eastern-South-Dakota.pdf.

Johnson, R.R., Higgins, K.F., Kjellsen, M.L., and Elliott, C.R., 1997, Eastern South Dakota wetlands: Brookings, South Dakota, South Dakota State University, 28 p., accessed January 20, 2017, at https://www.fws.gov/wetlands/Documents/Eastern-South-Dakota-Wetlands.pdf.

Johnson, W.C., Millett, B.V., Gilmanov, T., Voldseth, R.A., Guntenspergen, G.R., and Naugle, D.E., 2005, Vulnerability of northern prairie wetlands to climate change: BioScience, v. 55, no. 10, p. 863-872. [Also available at https://doi.org/10.1641/00063568(2005)055[0863:VONPWT]2.0.CO;2.]

Kantrud, H.A., Krapu, G.L., and Swanson G.A., 1989a, Prairie basin wetlands of the Dakotas: a community profile: Washington, D.C., U.S. Fish and Wildlife Service, Biological Report 85(7.28), 111 p.

Kantrud, H.A., Millar, J.B., and van der Valk, A.G., 1989b, Vegetation of wetlands of the Prairie Pothole Region, in van der Valk, A.G., ed., Northern prairie wetlands: Ames, Iowa, Iowa State University, p. 132-187.

Kantrud, H.A., and Newton, W.E., 1996, A test of vegetation-related indicators of wetland quality in the Prairie Pothole Region: Journal of Aquatic Ecosystem Health, v. 5, no. 3, p. 177191. [Also available at https://doi.org/10.1007/BF00124105.]

Kantrud, H.A., and Stewart, R.E., 1977, Use of natural basin wetlands by breeding waterfowl in North Dakota: Journal of Wildlife Management, v. 41, no. 2, p. 243-253.

Kantrud, H.A., and Stewart, R.E., 1984, Ecological distribution and crude density of breeding birds on prairie wetlands: Journal of Wildlife Management, v. 48, no. 2, p. 426-437.

Labbe, M.A., and King, D.I., 2014, The effect of local and landscape-level characteristics on the abundance of forest birds in early-successional habitats during the post-fledging season in western Massachusetts: PLoS ONE, v. 9, no. 8, e106398, 10 p. [Also available at https://doi.org/10.1371/journal.pone.0106398.]

LaGrange, T.G., and Dinsmore, J.J., 1989, Plant and animal responses to restored wetlands: Prairie Naturalist, v. 21, no. 1, p. 39-48. 
Lark, T.J., Salmon, J.M., and Gibbs, H.K., 2015, Cropland expansion outpaces agricultural and biofuel policies in the United States: Environmental Research Letters, v. 10, no. 4, 11 p. [Also available at https://doi.org/10.1088/1748-9326/10/4/044003.]

Locky, D.A., Davies, J.C., and Warner, B.G., 2005, Effects of wetland creation on breeding season bird use in boreal eastern Ontario: The Canadian Field-Naturalist, v. 119, no. 1, p. 6475. [Also available at https://doi.org/10.22621/cfn.v119i1.82.]

Marlow, J.W., Igl, L.D., and Hartman, M.R., 1996, Second record of White Ibis in North Dakota: Prairie Naturalist, v. 28, no. 3, p. 141-142.

Martin, T.E., Paine, C.R., Conway, C.J., Hochachka, W.M., Allen, P., and Jenkins, W., 1997, BBIRD grassland protocol: Missoula, Mont., U.S. Geological Survey, Montana Cooperative Wildlife Research Unit, University of Montana, 35 p., accessed January 20, 2017, at http://www.umt.edu/bbird/docs/GRASSLND.pdf.

Milliken, G.A., and Johnson, D.E., 2002, Analysis of messy data-Volume III-Analysis of covariance: New York, Chapman and Hall/CRC, 624 p.

Mitsch, W.J., and Gosselink, J.G., 2000, Wetlands (3d ed.): New York, John Wiley and Sons, 920 p.

Muir Hotaling, N.E., Kuenzel, W.J., and Douglass, L.W., 2002, Breeding season bird use of restored wetlands in eastern Maryland: Southeastern Naturalist, v. 1, no. 3, p. 233-252. [Also available at http://www.jstor.org/stable/3878040.]

Mushet, D.M., 2016, Midcontinent prairie-pothole wetlands and climate change-An introduction to the supplemental issue: Wetlands, v. 36, supplement 2, p. S223-S228. [Also available at https://doi.org/10.1007/s13157-016-0852-6.]

National Oceanic and Atmospheric Administration, 2017, Climate data online: Ashville, N.C., U.S. Department of Commerce, National Oceanic and Atmospheric Administration, National Centers for Environmental Information, accessed on January 20, 2017 at https://www.ncdc.noaa.gov/cdo-web/.

Naugle, D.E., Higgins, K.F., Estey, M.E., Johnson, R.R., and Nusser, S.M., 2000a, Local and landscape-level factors influencing Black Tern habitat suitability: Journal of Wildlife Management, v. 64, no. 1, p. 253-260. [Also available at https://doi.org/10.2307/3802997.]

Naugle, D.E., Johnson, R.R., Estey, M.E., and Higgins, K.F., 2000b, A landscape approach to conserving wetland bird habitat in the Prairie Pothole Region of eastern South Dakota: Wetlands, v. 21, no. 4, p. 588-604. [Also available at https://doi.org/10.1672/02775212(2000)020[0588:ALATCW]2.0.CO;2.]

Niemuth, N.D., Estey, M.E., Fields, S.P., Wangler, B., Bishop, A.A., Moore, P.J., Grosse, R.C., and Ryba, A.J., in press, Developing spatial models to guide conservation of grassland birds in the U.S. northern Great Plains: Condor.

Niemuth, N.D., Estey, M.E., Reynolds, R.E, Loesch, C.R., and Meeks, W.A., 2006, Use of wetlands by spring migrant shorebirds in agricultural landscapes of North Dakota's Drift Prairie: Wetlands, v. 26, no. 1, p. 30-39. [Also available at https://doi.org/10.1672/02775212(2006)26[30:UOWBSS]2.0.CO;2.]

Niemuth, N.D., Reynolds, R.E., Granfors, D.A., Johnson, R.E., Wangler, B., and Estey, M.E., 2008, Landscape-level planning for conservation of wetland birds in the U.S. Prairie Pothole Region, chap. 20 of Millspaugh, J.J., and Thompson, F.R., III, eds., Models for planning wildlife conservation in large landscapes: Amsterdam, Netherlands, Elsevier Science, p. 533560. 
Niemuth, N.D., Wangler, B., and Reynolds, R.E., 2010, Spatial and temporal variation in wet area of wetlands in the Prairie Pothole Region of North Dakota and South Dakota: Wetlands, v. 30, no. 6, p. 1053-1064. [Also available at https://doi.org/10.1007/s13157-010-0111-1.]

Peterjohn, B.G., and Sauer, J.R., 1999, Population status of North American grassland birds from the North American Breeding Bird Survey, 1966-1996: Studies in Avian Biology, v. 19, p. 27-44.

Peterson, S.A., Carpenter, L., Guntenspergen, G., and Cowardin, L.M., eds., 1997, Pilot test of wetland condition indicators in the Prairie Pothole Region of the United States: Corvallis, Oreg., U.S. Environmental Protection Agency, EPA/620/R-97/002, 279 p., accessed on January 20, 2017 at https://nepis.epa.gov/Exe/ZyPDF.cgi/91017HG0.PDF?Dockey=91017HG0.pdf.

Petit, L.J., Petit, D.R., and Martin, T.E., 1995, Landscape-level management of migratory birds_-Looking past the trees to see the forest: Wildlife Society Bulletin, v. 23, no. 3, p. 420429. [Also available at http://www.jstor.org/stable/3782949.]

Rashford, B.S., Walker, J.A., and Bastian, C.T., 2011, Economics of grassland conversion to cropland in the Prairie Pothole Region: Conservation Biology, v. 25, no. 2, p. 276-284. [Also available at https://doi.org/10.1111/j.1523-1739.2010.01618.x.]

Ratti, J.T., Rocklage, A.M., Giudice, J.H., Garton, E.O., and Golner, D.P., 2001, Comparison of avian communities on restored and natural wetlands in North and South Dakota: Journal of Wildlife Management, v. 60, no. 4, p. 676-684. [Also available at https://doi.org/10.2307/3803019.]

Ribic, C.A., Lewis, S.J., Melvin, S., Bart, J., and Peterjohn, B., 1999, Proceedings of the Marsh Bird Monitoring Workshop: Laurel, Md., U.S. Fish and Wildlife Service, 52 p., accessed on January 20, 2017 at https://digitalmedia.fws.gov/utils/getdownloaditem/collection/document/id/263/filename/55.pd f/mapsto/pdf/type/singleitem.

Robbins, C.S., Bystrak, D., and Geissler, P.H., 1986, The Breeding Bird Survey: its first fifteen years, 1965-1979: Washington, D.C., U.S. Fish and Wildlife Service, Resource Publication 157, 196 p. [Also available at https://pubs.er.usgs.gov/publication/5230189.]

Rosselli, L., and Stiles, F.G., 2012, Local and landscape environmental factors are important for the conservation of endangered wetland birds in a High Andean Plateau: Waterbirds, v. 35, no. 3, p. 453-469. [Also available at https://doi.org/10.1675/063.035.0310.]

SAS Institute, Inc., 2015, SAS/STAT® 14.1 user’s guide: Cary, N.C., SAS Institute Inc., accessed on January 20, 2017, at http://support.sas.com/documentation/cdl/en/statug/68162/HTML/default/viewer.htm\#titlepage .htm.

Schafer, J.L., 1996, A comparison of blackbird reproductive success in natural and restored Iowa wetlands: Ames, Iowa, Iowa State University, Master’s Thesis, 69 p.

Schreiber, J.A., 1994, Structure of breeding-bird communities on natural and restored Iowa wetlands: Ames, Iowa, Iowa State University, Master’s Thesis, 87 p.

Sebastián-González, E., and Green, A.J., 2014, Habitat use by waterbirds in relation to pond size, water depth, and isolation-Lessons from a restoration in southern Spain: Restoration Ecology, v. 22, no. 3, p 311-318. [Also available at https://doi.org/10.1111/rec.12078.]

Sebastián-González, E., and Green, A.J., 2016, Reduction of avian diversity in created versus natural and restored wetlands: Ecography, v. 39, no. 12, p. 1176-1184. [Also available at https://doi.org/10.1111/ecog.01736.] 
Semlitsch, R.D., and Bodie, J.R., 1998, Are small, isolated wetlands expendable?: Conservation Biology, v. 12, no. 5, p. 1129-1133. [Also available at https://doi.org/10.1046/j.15231739.1998.98166.x.]

Sewell, R.W., and Higgins, K.F., 1991, Floral and faunal colonization of restored wetlands in west-central Minnesota and northeastern South Dakota: Proceedings of the Annual conference on Wetland Restoration and Creation, v. 18, p. 108-133.

Skagen, S.K., and Thompson, G., 2013, The U.S. shorebird conservation plan-Northern Plains/Prairie Potholes Regional shorebird conservation plan (ver. 1.0): Manomet, Mass., Manomet Center for Conservation Sciences, 33 p., accessed on January 20, 2017, at https://www.shorebirdplan.org/wp-content/uploads/2013/01/NORPLPP2.pdf.

South Dakota Department of Game, Fish and Parks, 2014, South Dakota Wildlife Action Plan:

Pierre, S. Dak., South Dakota Department of Game, Fish and Parks, Wildlife Division Report 2014-03, 551 p., accessed on January 20, 2017, at http://gfp.sd.gov/wildlife/management/plans/wildlife-action-plan.aspx.

Stephens, S.E., Walker, J.A., Blunck, D.R., Jayaraman, A., Naugle, D.E., Ringelman, J.K., and Smith, A.J., 2008, Predicting risk of habitat conversion in native temperate grasslands: Conservation Biology, v. 22, no. 5, p. 1320-1330. [Also available at https://doi.org/10.1111/j.1523-1739.2008.01022.x.]

Stewart, R.E., 1975, Breeding birds of North Dakota: Fargo, N. Dak., Tri-College Center for Environmental Studies, 295 p.

Stewart, R.E., and Kantrud, H.A., 1971, Classification of natural ponds and lakes in the glaciated prairie region: Washington, D.C., U.S. Department of Interior, Bureau of Sport Fisheries and Wildlife, Resource Publication 92, 57 p., accessed on January 20, 2017, at https://pubs.usgs.gov/rp/092/report.pdf.

Stewart, R.E., and Kantrud, H.A., 1972, Population estimates of breeding birds in North Dakota: The Auk, v. 89, no. 4, p. 766-788. [Also available at https://doi.org/10.2307/4084108.]

Stewart, R.E., and Kantrud, H.A., 1973, Ecological distribution of breeding waterfowl in North Dakota: Journal of Wildlife Management, v. 37, no. 1, p. 39-50.

Tozer, D.C., Nol, E., and Abraham, K.F., 2010, Effects of local and landscape-scale habitat variables on abundance and reproductive success of wetland birds: Wetland Ecology and Management, v. 18, no. 6, p. 679-693. [Also available at https://doi.org/10.1007/s11273-0109187-X.]

Tsai, J.-S., 2007, Local and landscape factor influences on avian community composition in playas of the southern High Plains: Lubbock, Tex., Texas Tech University, Ph.D. Dissertation, 208 p.

U.S. Fish and Wildlife Service [USFWS], 2008, Birds of Conservation Concern 2008: Arlington, Va., Fish and Wildlife Service, Division of Migratory Bird Management, 87 p., accessed on January 20, 2017, at https://www.fws.gov/migratorybirds/pdf/grants/BirdsofConservationConcern2008.pdf. van der Valk, A.G., 2005, Water-level fluctuations in North American prairie wetlands: Hydrobiologia, v. 539, no. 1, p. 171-188. [Also available at https://doi.org/10.1007/s10750004-4866-3.]

VanRees-Siewert, K.L., and Dinsmore, J.J., 1996, Influences of wetland age on bird use of restored wetlands in Iowa: Wetlands, v. 16, no. 4, p. 577-582. [Also available at https://doi.org/10.1007/BF03161348.] 
Vickery, P.D., Tubaro, P.L., Cardosa da Silva, J.M., Peterjohn, B.G., Herkert, J.R., and Cavalcanti, R.B., 1999, Conservation of grassland birds in the Western Hemisphere: Studies in Avian Biology, v. 19, p. 2-26.

Webb, E.B., Smith, L.M., Vrtiska, M.P., and Lagrange, T.G., 2010, Effects of local and landscape variables on wetland bird use during migration through the Rainwater Basin: Journal of Wildlife Management, v. 74, no. 1, p. 109-119. [Also available at https://doi.org/10.2193/2008-577.]

Weller, M.W., 1999, Wetland birds-Habitat resources and conservation implications: Cambridge, United Kingdom, Cambridge University Press, 271 p.

Whittaker, R.H., and Likens, G.E., 1973, Primary production-The biosphere and man: Human Ecology, v. 1, no. 4, p. 357-369. [Also available at https://doi.org/10.1007/BF01536732.]

Wilen, B.O., and Bates, M.K., 1995, The U.S. Fish and Wildlife Service's National Wetlands Inventory project: Vegetatio, v. 118, p. 153-169.

Williams-Sether, T., 1999, From dry to wet, 1988-97, North Dakota: Bismarck, N. Dak., U.S. Geological Survey Fact Sheet FS-075-99, 4 p. [Also available at https://pubs.usgs.gov/fs/1999/0075/report.pdf.]

Williams-Sether, T, Macek-Rowland, K.M., and Emerson, D.G., 1994, Climatic and hydrologic aspects of the 1988-92 drought and the effect on people and resources in North Dakota: Bismarck, N. Dak., North Dakota State Water Commission, Water Resources Investigation 29, $57 \mathrm{p}$.

Winter, T.C., and Rosenberry, D.O., 1998, Hydrology of prairie pothole wetlands during drought and deluge-A 17-year study of the Cottonwood Lake wetland complex in North Dakota in the perspective of longer term measured and proxy hydrological records: Climate Change, v. 40, no. 2, p. 189-209. [Also available at https://doi.org/10.1023/A:1005448416571.]

Yerkes, T., 2000, Nest-site characteristics and brood-habitat selection of Redheads-An association between wetland characteristics and success: Wetlands, v. 20, no. 4, p. 575-580. [Also available at https://doi.org/10.1672/0277-5212(2000)020[0575:NSCABH]2.0.CO;2.] 


\section{Appendix 1. Summary Statistics for Wetland Breeding Bird Study in the Prairie Pothole Region of North and South Dakota in 1995-97}

Table 1-1. Total number of indicated breeding pairs observed in 1,190 wetland basins within the Prairie Pothole Region of North and South Dakota in 1995-97.

[Species are listed in order of abundance. Summaries are given across all 1,190 wetlands (includes zero counts for wetlands in which a species was not observed) and for only those wetlands in which the species was present. ---, no standard error because sample size equals one]

\begin{tabular}{|c|c|c|c|c|c|c|c|c|c|}
\hline \multirow[b]{2}{*}{ Common name } & \multirow[b]{2}{*}{ Scientific name } & \multirow{2}{*}{$\begin{array}{c}\text { Total } \\
\text { number } \\
\text { of pairs }\end{array}$} & \multicolumn{2}{|c|}{$\begin{array}{l}\text { Mean number of pairs } \\
\text { for all } 1,190 \text { wetlands }\end{array}$} & \multicolumn{5}{|c|}{$\begin{array}{l}\text { Summary statistics for number of breeding pairs for } \\
\text { only wetlands with species present }\end{array}$} \\
\hline & & & Mean & $\begin{array}{l}\text { Standard } \\
\text { error }\end{array}$ & $\begin{array}{c}\text { Number } \\
\text { of } \\
\text { wetlands } \\
\text { with } \\
\text { species } \\
\text { present }\end{array}$ & Mean & $\begin{array}{l}\text { Standard } \\
\text { error }\end{array}$ & Minimum & Maximum \\
\hline Yellow-headed Blackbird ${ }^{\mathrm{a}}$ & $\begin{array}{l}\text { Xanthocephalus } \\
\text { xanthocephalus }\end{array}$ & 4,454 & 3.743 & 0.324 & 470 & 9.477 & 0.747 & 1 & 162 \\
\hline Blue-winged Teal $^{\mathrm{a}}$ & Anas discors & 4,181 & 3.513 & 0.146 & 851 & 4.913 & 0.183 & 1 & 39 \\
\hline Red-winged Blackbird $^{\mathrm{a}}$ & Agelaius phoeniceus & 3,855 & 3.239 & 0.118 & 944 & 4.084 & 0.136 & 1 & 36 \\
\hline American Coot $^{\mathrm{a}}$ & Fulica americana & 2,861 & 2.404 & 0.158 & 595 & 4.808 & 0.283 & 1 & 96 \\
\hline Gadwall $^{\mathrm{a}}$ & Anas strepera & 1,932 & 1.624 & 0.115 & 565 & 3.419 & 0.219 & 1 & 71 \\
\hline Mallard $^{\mathrm{a}}$ & Anas platyrhynchos & 1,890 & 1.588 & 0.090 & 601 & 3.145 & 0.155 & 1 & 42 \\
\hline Marsh Wren & Cistothorus palustris & 1,378 & 1.158 & 0.115 & 242 & 5.694 & 0.465 & 1 & 61 \\
\hline Common Yellowthroat $^{\mathrm{a}}$ & Geothlypis trichas & 1,306 & 1.097 & 0.058 & 523 & 2.497 & 0.104 & 1 & 19 \\
\hline Black Tern & Chlidonias niger & 1,110 & 0.933 & 0.093 & 285 & 3.895 & 0.333 & 1 & 43 \\
\hline
\end{tabular}




\begin{tabular}{|c|c|c|c|c|c|c|c|c|c|}
\hline \multirow[b]{2}{*}{ Common name } & \multirow[b]{2}{*}{ Scientific name } & \multirow{2}{*}{$\begin{array}{c}\text { Total } \\
\text { number } \\
\text { of pairs }\end{array}$} & \multicolumn{2}{|c|}{$\begin{array}{l}\text { Mean number of pairs } \\
\text { for all } 1,190 \text { wetlands }\end{array}$} & \multicolumn{5}{|c|}{$\begin{array}{l}\text { Summary statistics for number of breeding pairs for } \\
\text { only wetlands with species present }\end{array}$} \\
\hline & & & Mean & $\begin{array}{l}\text { Standard } \\
\text { error }\end{array}$ & $\begin{array}{l}\text { Number } \\
\text { of } \\
\text { wetlands } \\
\text { with } \\
\text { species } \\
\text { present }\end{array}$ & Mean & $\begin{array}{l}\text { Standard } \\
\text { error }\end{array}$ & Minimum & Maximum \\
\hline Common Grackle & Quiscalus quiscula & 1,050 & 0.882 & 0.089 & 258 & 4.070 & 0.346 & 1 & 58 \\
\hline Ruddy Duck & Oxyura jamaicensis & 923 & 0.776 & 0.077 & 255 & 3.620 & 0.299 & 1 & 50 \\
\hline Northern Shoveler ${ }^{\mathrm{a}}$ & Anas clypeata & 812 & 0.682 & 0.052 & 331 & 2.453 & 0.148 & 1 & 25 \\
\hline Eared Grebe & Podiceps nigricollis & 769 & 0.646 & 0.220 & 55 & 13.982 & 4.428 & 1 & 173 \\
\hline Redhead & Aythya americana & 647 & 0.544 & 0.047 & 231 & 2.801 & 0.177 & 1 & 21 \\
\hline Savannah Sparrow ${ }^{\mathrm{a}}$ & Passerculus sandwichensis & 536 & 0.450 & 0.035 & 311 & 1.723 & 0.102 & 1 & 22 \\
\hline Sora & Porzana carolina & 476 & 0.400 & 0.028 & 283 & 1.682 & 0.081 & 1 & 10 \\
\hline Pied-billed Grebe & Podilymbus podiceps & 466 & 0.392 & 0.029 & 280 & 1.664 & 0.090 & 1 & 14 \\
\hline Eastern Kingbird & Tyrannus tyrannus & 453 & 0.381 & 0.030 & 256 & 1.770 & 0.097 & 1 & 13 \\
\hline Killdeer & Charadrius vociferus & 451 & 0.379 & 0.028 & 262 & 1.721 & 0.085 & 1 & 10 \\
\hline Lesser Scaup & Aythya affinis & 447 & 0.376 & 0.044 & 135 & 3.311 & 0.276 & 1 & 22 \\
\hline Brown-headed Cowbird & Molothrus ater & 425 & 0.357 & 0.034 & 211 & 2.014 & 0.144 & 1 & 19 \\
\hline Song Sparrow & Melospiza melodia & 414 & 0.348 & 0.026 & 237 & 1.747 & 0.085 & 1 & 9 \\
\hline Northern Pintail & Anas acuta & 386 & 0.324 & 0.031 & 210 & 1.838 & 0.133 & 1 & 19 \\
\hline Clay-colored Sparrow & Spizella pallida & 318 & 0.267 & 0.024 & 177 & 1.797 & 0.106 & 1 & 8 \\
\hline Bobolink & Dolichonyx oryzivorus & 316 & 0.266 & 0.020 & 216 & 1.463 & 0.063 & 1 & 5 \\
\hline Black-crowned Night-Heron & Nycticorax nycticorax & 315 & 0.265 & 0.110 & 67 & 4.701 & 1.885 & 1 & 110 \\
\hline
\end{tabular}




\begin{tabular}{|c|c|c|c|c|c|c|c|c|c|}
\hline \multirow[b]{2}{*}{ Common name } & \multirow[b]{2}{*}{ Scientific name } & \multirow{2}{*}{$\begin{array}{c}\text { Total } \\
\text { number } \\
\text { of pairs }\end{array}$} & \multicolumn{2}{|c|}{$\begin{array}{l}\text { Mean number of pairs } \\
\text { for all } 1,190 \text { wetlands }\end{array}$} & \multicolumn{5}{|c|}{$\begin{array}{l}\text { Summary statistics for number of breeding pairs for } \\
\text { only wetlands with species present }\end{array}$} \\
\hline & & & Mean & $\begin{array}{l}\text { Standard } \\
\text { error }\end{array}$ & $\begin{array}{l}\text { Number } \\
\text { of } \\
\text { wetlands } \\
\text { with } \\
\text { species } \\
\text { present }\end{array}$ & Mean & $\begin{array}{l}\text { Standard } \\
\text { error }\end{array}$ & Minimum & Maximum \\
\hline Franklin’s Gull & Leucophaeus pipixcan & 308 & 0.259 & 0.100 & 44 & 7.000 & 2.525 & 1 & 93 \\
\hline Barn Swallow & Hirundo rustica & 292 & 0.245 & 0.036 & 153 & 1.908 & 0.243 & 1 & 32 \\
\hline Green-winged Teal & Anas carolinensis & 273 & 0.229 & 0.033 & 141 & 1.936 & 0.232 & 1 & 26 \\
\hline Virginia Rail & Rallus limicola & 216 & 0.182 & 0.020 & 121 & 1.785 & 0.124 & 1 & 11 \\
\hline Sedge Wren & Cistothorus platensis & 200 & 0.168 & 0.017 & 127 & 1.575 & 0.096 & 1 & 9 \\
\hline Wilson's Phalarope & Phalaropus tricolor & 198 & 0.166 & 0.024 & 97 & 2.041 & 0.226 & 1 & 15 \\
\hline Ring-billed Gull & Larus delawarensis & 174 & 0.146 & 0.037 & 56 & 3.107 & 0.676 & 1 & 28 \\
\hline American White Pelican & Pelecanus erythrorhynchos & 172 & 0.145 & 0.037 & 34 & 5.059 & 0.971 & 1 & 23 \\
\hline Canvasback & Aythya valisineria & 169 & 0.142 & 0.024 & 63 & 2.683 & 0.313 & 1 & 15 \\
\hline Canada Goose & Branta canadensis & 133 & 0.112 & 0.025 & 59 & 2.254 & 0.414 & 1 & 21 \\
\hline Ring-necked Duck & Aythya collaris & 133 & 0.112 & 0.017 & 63 & 2.111 & 0.185 & 1 & 7 \\
\hline Cliff Swallow & Petrochelidon pyrrhonota & 130 & 0.109 & 0.020 & 62 & 2.097 & 0.275 & 1 & 10 \\
\hline American Wigeon & Anas americana & 124 & 0.104 & 0.022 & 57 & 2.175 & 0.371 & 1 & 18 \\
\hline American Bittern & Botaurus lentiginosus & 117 & 0.098 & 0.011 & 96 & 1.219 & 0.056 & 1 & 4 \\
\hline Yellow Warbler & Setophaga petechia & 117 & 0.098 & 0.017 & 59 & 1.983 & 0.234 & 1 & 11 \\
\hline Willet & Tringa semipalmata & 115 & 0.097 & 0.013 & 78 & 1.474 & 0.118 & 1 & 6 \\
\hline American Avocet & Recurvirostra americana & 112 & 0.094 & 0.023 & 29 & 3.862 & 0.615 & 1 & 13 \\
\hline
\end{tabular}




\begin{tabular}{|c|c|c|c|c|c|c|c|c|c|}
\hline \multirow[b]{2}{*}{ Common name } & \multirow[b]{2}{*}{ Scientific name } & \multirow{2}{*}{$\begin{array}{l}\text { Total } \\
\text { number } \\
\text { of pairs }\end{array}$} & \multicolumn{2}{|c|}{$\begin{array}{l}\text { Mean number of pairs } \\
\text { for all } 1,190 \text { wetlands }\end{array}$} & \multicolumn{5}{|c|}{$\begin{array}{l}\text { Summary statistics for number of breeding pairs for } \\
\text { only wetlands with species present }\end{array}$} \\
\hline & & & Mean & $\begin{array}{l}\text { Standard } \\
\text { error }\end{array}$ & $\begin{array}{l}\text { Number } \\
\text { of } \\
\text { wetlands } \\
\text { with } \\
\text { species } \\
\text { present }\end{array}$ & Mean & $\begin{array}{l}\text { Standard } \\
\text { error }\end{array}$ & Minimum & Maximum \\
\hline Mourning Dove & Zenaida macroura & 103 & 0.087 & 0.014 & 64 & 1.609 & 0.163 & 1 & 8 \\
\hline Western Meadowlark & Sturnella neglecta & 101 & 0.085 & 0.011 & 75 & 1.347 & 0.075 & 1 & 4 \\
\hline American Goldfinch & Spinus tristis & 96 & 0.081 & 0.012 & 63 & 1.524 & 0.143 & 1 & 9 \\
\hline Double-crested Cormorant & Phalacrocorax auritus & 96 & 0.081 & 0.021 & 38 & 2.526 & 0.514 & 1 & 18 \\
\hline Tree Swallow & Tachycineta bicolor & 91 & 0.076 & 0.014 & 64 & 1.422 & 0.201 & 1 & 13 \\
\hline Western Kingbird & Tyrannus verticalis & 82 & 0.069 & 0.010 & 66 & 1.242 & 0.097 & 1 & 6 \\
\hline Marbled Godwit & Limosa fedoa & 81 & 0.068 & 0.017 & 44 & 1.841 & 0.389 & 1 & 16 \\
\hline Le Conte’s Sparrow & Ammodramus leconteii & 79 & 0.066 & 0.012 & 47 & 1.681 & 0.175 & 1 & 7 \\
\hline Horned Grebe & Podiceps auritus & 74 & 0.062 & 0.022 & 28 & 2.643 & 0.791 & 1 & 22 \\
\hline Wood Duck & Aix sponsa & 73 & 0.061 & 0.012 & 39 & 1.872 & 0.195 & 1 & 5 \\
\hline Willow Flycatcher & Empidonax traillii & 72 & 0.061 & 0.012 & 39 & 1.846 & 0.216 & 1 & 6 \\
\hline Wilson’s Snipe & Gallinago delicata & 72 & 0.061 & 0.008 & 60 & 1.200 & 0.066 & 1 & 4 \\
\hline Upland Sandpiper & Bartramia longicauda & 66 & 0.055 & 0.008 & 55 & 1.200 & 0.071 & 1 & 4 \\
\hline Cattle Egret & Bubulcus ibis & 61 & 0.051 & 0.041 & 7 & 8.714 & 6.567 & 1 & 48 \\
\hline Swamp Sparrow & Melospiza georgiana & 52 & 0.044 & 0.009 & 30 & 1.733 & 0.209 & 1 & 6 \\
\hline Grasshopper Sparrow & Ammodramus savannarum & 42 & 0.035 & 0.006 & 35 & 1.200 & 0.069 & 1 & 2 \\
\hline Horned Lark & Eremophila alpestris & 36 & 0.030 & 0.007 & 26 & 1.385 & 0.167 & 1 & 4 \\
\hline
\end{tabular}




\begin{tabular}{|c|c|c|c|c|c|c|c|c|c|}
\hline \multirow[b]{2}{*}{ Common name } & \multirow[b]{2}{*}{ Scientific name } & \multirow{2}{*}{$\begin{array}{c}\text { Total } \\
\text { number } \\
\text { of pairs }\end{array}$} & \multicolumn{2}{|c|}{$\begin{array}{l}\text { Mean number of pairs } \\
\text { for all } 1,190 \text { wetlands }\end{array}$} & \multicolumn{5}{|c|}{$\begin{array}{l}\text { Summary statistics for number of breeding pairs for } \\
\text { only wetlands with species present }\end{array}$} \\
\hline & & & Mean & $\begin{array}{l}\text { Standard } \\
\text { error }\end{array}$ & $\begin{array}{c}\text { Number } \\
\text { of } \\
\text { wetlands } \\
\text { with } \\
\text { species } \\
\text { present }\end{array}$ & Mean & $\begin{array}{l}\text { Standard } \\
\text { error }\end{array}$ & Minimum & Maximum \\
\hline Cedar Waxwing & Bombycilla cedrorum & 35 & 0.029 & 0.018 & 6 & 5.833 & 2.937 & 1 & 20 \\
\hline Chestnut-collared Longspur & Calcarius ornatus & 34 & 0.029 & 0.008 & 18 & 1.889 & 0.322 & 1 & 5 \\
\hline Bank Swallow & Riparia riparia & 33 & 0.028 & 0.010 & 15 & 2.200 & 0.571 & 1 & 8 \\
\hline Ring-necked Pheasant & Phasianus colchicus & 26 & 0.022 & 0.005 & 22 & 1.182 & 0.142 & 1 & 4 \\
\hline American Robin & Turdus migratorius & 23 & 0.019 & 0.004 & 21 & 1.095 & 0.066 & 1 & 2 \\
\hline Gray Catbird & Dumetella carolinensis & 23 & 0.019 & 0.005 & 17 & 1.353 & 0.147 & 1 & 3 \\
\hline House Wren & Troglodytes aedon & 23 & 0.019 & 0.005 & 20 & 1.150 & 0.109 & 1 & 3 \\
\hline Nelson’s Sparrow & Ammodramus nelsoni & 22 & 0.018 & 0.004 & 20 & 1.100 & 0.069 & 1 & 2 \\
\hline Least Flycatcher & Empidonax minimus & 21 & 0.018 & 0.006 & 12 & 1.750 & 0.351 & 1 & 5 \\
\hline Northern Harrier & Circus cyaneus & 21 & 0.018 & 0.004 & 20 & 1.050 & 0.050 & 1 & 2 \\
\hline Piping Plover & Charadrius melodus & 20 & 0.017 & 0.006 & 10 & 2.000 & 0.447 & 1 & 5 \\
\hline Baird’s Sparrow & Ammodramus bairdii & 18 & 0.015 & 0.004 & 14 & 1.286 & 0.125 & 1 & 2 \\
\hline Baltimore Oriole & Icterus galbula & 18 & 0.015 & 0.004 & 18 & 1.000 & 0.000 & 1 & 1 \\
\hline Western Grebe & Aechmophorus occidentalis & 18 & 0.015 & 0.005 & 13 & 1.385 & 0.180 & 1 & 3 \\
\hline Northern Flicker & Colaptes auratus & 17 & 0.014 & 0.003 & 17 & 1.000 & 0.000 & 1 & 1 \\
\hline Bufflehead & Bucephala albeola & 16 & 0.013 & 0.004 & 11 & 1.455 & 0.207 & 1 & 3 \\
\hline Lesser Yellowlegs ${ }^{\mathrm{b}}$ & Tringa flavipes & 16 & 0.013 & 0.005 & 9 & 1.778 & 0.222 & 1 & 3 \\
\hline
\end{tabular}




\begin{tabular}{|c|c|c|c|c|c|c|c|c|c|}
\hline \multirow[b]{2}{*}{ Common name } & \multirow[b]{2}{*}{ Scientific name } & \multirow{2}{*}{$\begin{array}{l}\text { Total } \\
\text { number } \\
\text { of pairs }\end{array}$} & \multicolumn{2}{|c|}{$\begin{array}{l}\text { Mean number of pairs } \\
\text { for all } 1,190 \text { wetlands }\end{array}$} & \multicolumn{5}{|c|}{$\begin{array}{l}\text { Summary statistics for number of breeding pairs for } \\
\text { only wetlands with species present }\end{array}$} \\
\hline & & & Mean & $\begin{array}{l}\text { Standard } \\
\text { error }\end{array}$ & $\begin{array}{l}\text { Number } \\
\text { of } \\
\text { wetlands } \\
\text { with } \\
\text { species } \\
\text { present }\end{array}$ & Mean & $\begin{array}{l}\text { Standard } \\
\text { error }\end{array}$ & Minimum & Maximum \\
\hline Orchard Oriole & Icterus spurius & 16 & 0.013 & 0.003 & 16 & 1.000 & 0.000 & 1 & 1 \\
\hline Forster’s Tern & Sterna forsteri & 15 & 0.013 & 0.007 & 7 & 2.143 & 0.829 & 1 & 7 \\
\hline Red-tailed Hawk & Buteo jamaicensis & 15 & 0.013 & 0.004 & 11 & 1.364 & 0.203 & 1 & 3 \\
\hline Northern Rough-winged Swallow & Stelgidopteryx serripennis & 14 & 0.012 & 0.004 & 10 & 1.400 & 0.163 & 1 & 2 \\
\hline California Gull & Larus californicus & 13 & 0.011 & 0.003 & 11 & 1.182 & 0.122 & 1 & 2 \\
\hline Great Blue Heron & Ardea herodias & 13 & 0.011 & 0.003 & 12 & 1.083 & 0.083 & 1 & 2 \\
\hline Dickcissel & Spiza americana & 12 & 0.010 & 0.003 & 11 & 1.091 & 0.091 & 1 & 2 \\
\hline Brown Thrasher & Toxostoma rufum & 10 & 0.008 & 0.003 & 9 & 1.111 & 0.111 & 1 & 2 \\
\hline Great Horned Owl & Bubo virginianus & 10 & 0.008 & 0.003 & 10 & 1.000 & 0.000 & 1 & 1 \\
\hline Vesper Sparrow & Pooecetes gramineus & 9 & 0.008 & 0.003 & 6 & 1.500 & 0.342 & 1 & 3 \\
\hline Warbling Vireo & Vireo gilvus & 9 & 0.008 & 0.003 & 9 & 1.000 & 0.000 & 1 & 1 \\
\hline White-rumped Sandpiper ${ }^{b}$ & Calidris fuscicollis & 9 & 0.008 & 0.005 & 2 & 4.500 & 0.500 & 4 & 5 \\
\hline Red-necked Grebe & Podiceps grisegena & 8 & 0.007 & 0.003 & 6 & 1.333 & 0.211 & 1 & 2 \\
\hline Spotted Sandpiper & Actitis macularius & 8 & 0.007 & 0.004 & 4 & 2.000 & 0.707 & 1 & 4 \\
\hline White-faced Ibis & Plegadis chihi & 8 & 0.007 & 0.006 & 2 & 4.000 & 3.000 & 1 & 7 \\
\hline Least Sandpiper ${ }^{b}$ & Calidris minutilla & 7 & 0.006 & 0.003 & 5 & 1.400 & 0.400 & 1 & 3 \\
\hline Hooded Merganser & Lophodytes cucullatus & 6 & 0.005 & 0.002 & 5 & 1.200 & 0.200 & 1 & 2 \\
\hline
\end{tabular}




\begin{tabular}{|c|c|c|c|c|c|c|c|c|c|}
\hline \multirow[b]{2}{*}{ Common name } & \multirow[b]{2}{*}{ Scientific name } & \multirow{2}{*}{$\begin{array}{l}\text { Total } \\
\text { number } \\
\text { of pairs }\end{array}$} & \multicolumn{2}{|c|}{$\begin{array}{l}\text { Mean number of pairs } \\
\text { for all } 1,190 \text { wetlands }\end{array}$} & \multicolumn{5}{|c|}{$\begin{array}{l}\text { Summary statistics for number of breeding pairs for } \\
\text { only wetlands with species present }\end{array}$} \\
\hline & & & Mean & $\begin{array}{l}\text { Standard } \\
\text { error }\end{array}$ & $\begin{array}{l}\text { Number } \\
\text { of } \\
\text { wetlands } \\
\text { with } \\
\text { species } \\
\text { present }\end{array}$ & Mean & $\begin{array}{l}\text { Standard } \\
\text { error }\end{array}$ & Minimum & Maximum \\
\hline Great Egret & Ardea alba & 5 & 0.004 & 0.002 & 5 & 1.000 & 0.000 & 1 & 1 \\
\hline Short-eared Owl & Asio flammeus & 5 & 0.004 & 0.002 & 5 & 1.000 & 0.000 & 1 & 1 \\
\hline Bullock’s Oriole & Icterus bullockii & 4 & 0.003 & 0.002 & 4 & 1.000 & 0.000 & 1 & 1 \\
\hline Common Nighthawk & Chordeiles minor & 4 & 0.003 & 0.002 & 3 & 1.333 & 0.333 & 1 & 2 \\
\hline Greater Yellowlegs ${ }^{b}$ & Tringa melanoleuca & 4 & 0.003 & 0.002 & 3 & 1.333 & 0.333 & 1 & 2 \\
\hline Yellow-rumped Warbler ${ }^{\mathrm{b}}$ & Setophaga coronata & 4 & 0.003 & 0.003 & 2 & 2.000 & 1.000 & 1 & 3 \\
\hline American Crow & Corvus brachyrhynchos & 3 & 0.003 & 0.002 & 2 & 1.500 & 0.500 & 1 & 2 \\
\hline American Redstart $^{\mathrm{b}}$ & Setophaga ruticilla & 3 & 0.003 & 0.001 & 3 & 1.000 & 0.000 & 1 & 1 \\
\hline Gray Partridge & Perdix perdix & 3 & 0.003 & 0.001 & 3 & 1.000 & 0.000 & 1 & 1 \\
\hline House Sparrow & Passer domesticus & 3 & 0.003 & 0.001 & 3 & 1.000 & 0.000 & 1 & 1 \\
\hline Least Bittern & Ixobrychus exilis & 3 & 0.003 & 0.001 & 3 & 1.000 & 0.000 & 1 & 1 \\
\hline Swainson’s Hawk & Buteo swainsoni & 3 & 0.003 & 0.001 & 3 & 1.000 & 0.000 & 1 & 1 \\
\hline Common Goldeneye & Bucephala clangula & 2 & 0.002 & 0.002 & 1 & 2.000 & --- & 2 & 2 \\
\hline Downy Woodpecker & Picoides pubescens & 2 & 0.002 & 0.001 & 2 & 1.000 & 0.000 & 1 & 1 \\
\hline Red-eyed Vireo ${ }^{\text {b }}$ & Vireo olivaceus & 2 & 0.002 & 0.001 & 2 & 1.000 & 0.000 & 1 & 1 \\
\hline Rock Pigeon & Columba livia & 2 & 0.002 & 0.002 & 1 & 2.000 & --- & 2 & 2 \\
\hline Semipalmated Sandpiper ${ }^{\mathrm{b}}$ & Calidris pusilla & 2 & 0.002 & 0.002 & 1 & 2.000 & --- & 2 & 2 \\
\hline
\end{tabular}




\begin{tabular}{|c|c|c|c|c|c|c|c|c|c|}
\hline \multirow[b]{2}{*}{ Common name } & \multirow[b]{2}{*}{ Scientific name } & \multirow{2}{*}{$\begin{array}{l}\text { Total } \\
\text { number } \\
\text { of pairs }\end{array}$} & \multicolumn{2}{|c|}{$\begin{array}{l}\text { Mean number of pairs } \\
\text { for all } 1,190 \text { wetlands }\end{array}$} & \multicolumn{5}{|c|}{$\begin{array}{l}\text { Summary statistics for number of breeding pairs for } \\
\text { only wetlands with species present }\end{array}$} \\
\hline & & & Mean & $\begin{array}{l}\text { Standard } \\
\text { error }\end{array}$ & $\begin{array}{l}\text { Number } \\
\text { of } \\
\text { wetlands } \\
\text { with } \\
\text { species } \\
\text { present }\end{array}$ & Mean & $\begin{array}{l}\text { Standard } \\
\text { error }\end{array}$ & Minimum & Maximum \\
\hline Sprague’s Pipit & Anthus spragueii & 2 & 0.002 & 0.002 & 1 & 2.000 & --- & 2 & 2 \\
\hline Tennessee Warbler ${ }^{\mathrm{b}}$ & Leiothlypis peregrina & 2 & 0.002 & 0.002 & 1 & 2.000 & --- & 2 & 2 \\
\hline Belted Kingfisher & Megaceryle alcyon & 1 & 0.001 & 0.001 & 1 & 1.000 & --- & 1 & 1 \\
\hline Blackpoll Warbler ${ }^{\mathrm{b}}$ & Setophaga striata & 1 & 0.001 & 0.001 & 1 & 1.000 & --- & 1 & 1 \\
\hline Brewer’s Blackbird & Euphagus cyanocephalus & 1 & 0.001 & 0.001 & 1 & 1.000 & --- & 1 & 1 \\
\hline Canada Warbler ${ }^{\mathrm{b}}$ & Cardellina canadensis & 1 & 0.001 & 0.001 & 1 & 1.000 & --- & 1 & 1 \\
\hline Chipping Sparrow & Spizella passerina & 1 & 0.001 & 0.001 & 1 & 1.000 & --- & 1 & 1 \\
\hline Common Tern & Sterna hirundo & 1 & 0.001 & 0.001 & 1 & 1.000 & --- & 1 & 1 \\
\hline Eastern Bluebird & Sialia sialis & 1 & 0.001 & 0.001 & 1 & 1.000 & --- & 1 & 1 \\
\hline Eastern Wood Pewee & Contopus virens & 1 & 0.001 & 0.001 & 1 & 1.000 & --- & 1 & 1 \\
\hline Ferruginous Hawk & Buteo regalis & 1 & 0.001 & 0.001 & 1 & 1.000 & --- & 1 & 1 \\
\hline Great Crested Flycatcher & Myiarchus crinitus & 1 & 0.001 & 0.001 & 1 & 1.000 & --- & 1 & 1 \\
\hline Great-tailed Grackle & Quiscalus mexicanus & 1 & 0.001 & 0.001 & 1 & 1.000 & --- & 1 & 1 \\
\hline Lark Sparrow & Chondestes grammacus & 1 & 0.001 & 0.001 & 1 & 1.000 & --- & 1 & 1 \\
\hline Purple Martin & Progne subis & 1 & 0.001 & 0.001 & 1 & 1.000 & --- & 1 & 1 \\
\hline Sharp-tailed Grouse & Tympanuchus phasianellus & 1 & 0.001 & 0.001 & 1 & 1.000 & --- & 1 & 1 \\
\hline Snow Goose ${ }^{\mathrm{b}}$ & Chen caerulescens & 1 & 0.001 & 0.001 & 1 & 1.000 & --- & 1 & 1 \\
\hline
\end{tabular}




\begin{tabular}{|c|c|c|c|c|c|c|c|c|c|}
\hline \multirow[b]{2}{*}{ Common name } & \multirow[b]{2}{*}{ Scientific name } & \multirow{2}{*}{$\begin{array}{c}\text { Total } \\
\text { number } \\
\text { of pairs }\end{array}$} & \multicolumn{2}{|c|}{$\begin{array}{l}\text { Mean number of pairs } \\
\text { for all } 1,190 \text { wetlands }\end{array}$} & \multicolumn{5}{|c|}{$\begin{array}{l}\text { Summary statistics for number of breeding pairs for } \\
\text { only wetlands with species present }\end{array}$} \\
\hline & & & Mean & $\begin{array}{l}\text { Standard } \\
\text { error }\end{array}$ & $\begin{array}{c}\text { Number } \\
\text { of } \\
\text { wetlands } \\
\text { with } \\
\text { species } \\
\text { present }\end{array}$ & Mean & $\begin{array}{l}\text { Standard } \\
\text { error }\end{array}$ & Minimum & Maximum \\
\hline Snowy Egret & Egretta thula & 1 & 0.001 & 0.001 & 1 & 1.000 & --- & 1 & 1 \\
\hline Veery & Catharus fuscescens & 1 & 0.001 & 0.001 & 1 & 1.000 & --- & 1 & 1 \\
\hline White Ibis ${ }^{\mathrm{b}}$ & Eudocimus albus & 1 & 0.001 & 0.001 & 1 & 1.000 & --- & 1 & 1 \\
\hline Wilson's Warbler ${ }^{\mathrm{b}}$ & Cardellina pusilla & 1 & 0.001 & 0.001 & 1 & 1.000 & --- & 1 & 1 \\
\hline Wood Thrush $^{\mathrm{b}}$ & Hylocichla mustelina & 1 & 0.001 & 0.001 & 1 & 1.000 & --- & 1 & 1 \\
\hline
\end{tabular}

${ }^{\mathrm{a}}$ Species that were present in 25 percent or more of the 1,190 wetlands (that is, focal species).

${ }^{\mathrm{b}}$ Species that typically do not breed in North Dakota or South Dakota wetlands, including migrants, vagrants, and oversummering shorebirds and waterfowl that breed in the tundra and boreal regions of northern North America. 
Table 1-2. Proportion of wetlands in which each species was present surveyed in the Prairie Pothole Region of North and South Dakota in 199597.

[Species are listed in order of abundance. Proportions are given for the wetlands overall (1,190 wetlands surveyed); and by wetland class (alkali, permanent, semipermanent, seasonal, or temporary), wetland type (natural or restored), and landowner group (private or Federal). The numbers within parentheses in the column headings indicate the number of wetlands in each category. Alpha code, four-letter species code]

\begin{tabular}{|c|c|c|c|c|c|c|c|c|c|c|c|}
\hline \multirow{2}{*}{ Common name } & \multirow{2}{*}{$\begin{array}{l}\text { Alpha } \\
\text { code }\end{array}$} & \multirow{2}{*}{$\begin{array}{c}\text { Proportion } \\
\text { of } \\
\text { wetlands } \\
\text { surveyed } \\
\text { with } \\
\text { species } \\
\text { present } \\
(1,190)\end{array}$} & \multicolumn{5}{|c|}{$\begin{array}{l}\text { Proportion of wetlands surveyed } \\
\text { by wetland class with species present }\end{array}$} & \multicolumn{2}{|c|}{$\begin{array}{c}\text { Proportion of } \\
\text { wetlands surveyed } \\
\text { by wetland type with } \\
\text { species present }\end{array}$} & \multicolumn{2}{|c|}{$\begin{array}{c}\text { Proportion of } \\
\text { wetlands surveyed by } \\
\text { landowner group with } \\
\text { species present }\end{array}$} \\
\hline & & & $\begin{array}{l}\text { Alkali } \\
\text { (44) }\end{array}$ & $\begin{array}{l}\text { Permanent } \\
\quad(47)\end{array}$ & $\begin{array}{c}\text { Semiper- } \\
\text { manent } \\
(524)\end{array}$ & $\begin{array}{l}\text { Seasonal } \\
(410)\end{array}$ & $\begin{array}{l}\text { Temporary } \\
\text { (165) }\end{array}$ & $\begin{array}{c}\text { Natural } \\
(764)\end{array}$ & $\begin{array}{l}\text { Restored } \\
\quad(426)\end{array}$ & $\begin{array}{l}\text { Private } \\
(610)\end{array}$ & $\begin{array}{l}\text { Federal } \\
(\mathbf{5 8 0 )}\end{array}$ \\
\hline Red-winged Blackbird & RWBL & 0.793 & 0.727 & 0.872 & 0.872 & 0.795 & 0.533 & 0.788 & 0.803 & 0.744 & 0.845 \\
\hline Blue-winged Teal & BWTE & 0.715 & 0.955 & 0.936 & 0.786 & 0.722 & 0.345 & 0.725 & 0.697 & 0.652 & 0.781 \\
\hline Mallard & MALL & 0.505 & 0.727 & 0.936 & 0.582 & 0.451 & 0.212 & 0.510 & 0.495 & 0.428 & 0.586 \\
\hline American Coot & AMCO & 0.500 & 0.591 & 0.894 & 0.595 & 0.454 & 0.176 & 0.542 & 0.425 & 0.425 & 0.579 \\
\hline Gadwall & GADW & 0.475 & 0.955 & 0.851 & 0.500 & 0.446 & 0.230 & 0.478 & 0.469 & 0.413 & 0.540 \\
\hline Common Yellowthroat & COYE & 0.439 & 0.250 & 0.681 & 0.574 & 0.349 & 0.218 & 0.394 & 0.521 & 0.387 & 0.495 \\
\hline Yellow-headed Blackbird & YHBL & 0.395 & 0.341 & 0.787 & 0.594 & 0.234 & 0.067 & 0.428 & 0.336 & 0.300 & 0.495 \\
\hline Northern Shoveler & NSHO & 0.278 & 0.705 & 0.532 & 0.252 & 0.295 & 0.133 & 0.296 & 0.246 & 0.241 & 0.317 \\
\hline Savannah Sparrow & SAVS & 0.261 & 0.545 & 0.404 & 0.246 & 0.232 & 0.267 & 0.251 & 0.279 & 0.261 & 0.262 \\
\hline Black Tern & BLTE & 0.239 & 0.318 & 0.596 & 0.313 & 0.185 & 0.018 & 0.287 & 0.155 & 0.177 & 0.305 \\
\hline Sora & SORA & 0.238 & 0.295 & 0.404 & 0.294 & 0.188 & 0.121 & 0.238 & 0.237 & 0.225 & 0.252 \\
\hline Pied-billed Grebe & PBGR & 0.235 & 0.318 & 0.638 & 0.313 & 0.166 & 0.024 & 0.276 & 0.162 & 0.164 & 0.310 \\
\hline Killdeer & KILL & 0.220 & 0.568 & 0.574 & 0.206 & 0.212 & 0.091 & 0.232 & 0.200 & 0.225 & 0.216 \\
\hline Common Grackle & COGR & 0.217 & 0.341 & 0.553 & 0.282 & 0.149 & 0.048 & 0.262 & 0.136 & 0.172 & 0.264 \\
\hline
\end{tabular}




\begin{tabular}{|c|c|c|c|c|c|c|c|c|c|c|c|}
\hline \multirow{2}{*}{ Common name } & \multirow{2}{*}{$\begin{array}{l}\text { Alpha } \\
\text { code }\end{array}$} & \multirow{2}{*}{$\begin{array}{c}\text { Proportion } \\
\text { of } \\
\text { wetlands } \\
\text { surveyed } \\
\text { with } \\
\text { species } \\
\text { present } \\
(1,190)\end{array}$} & \multicolumn{5}{|c|}{$\begin{array}{l}\text { Proportion of wetlands surveyed } \\
\text { by wetland class with species present }\end{array}$} & \multicolumn{2}{|c|}{$\begin{array}{l}\text { Proportion of } \\
\text { wetlands surveyed } \\
\text { by wetland type with } \\
\text { species present }\end{array}$} & \multicolumn{2}{|c|}{$\begin{array}{l}\text { Proportion of } \\
\text { wetlands surveyed by } \\
\text { landowner group with } \\
\text { species present }\end{array}$} \\
\hline & & & $\begin{array}{l}\text { Alkali } \\
\text { (44) }\end{array}$ & $\begin{array}{l}\text { Permanent } \\
\quad(47)\end{array}$ & $\begin{array}{c}\text { Semiper- } \\
\text { manent } \\
(524)\end{array}$ & $\begin{array}{l}\text { Seasonal } \\
\quad(410)\end{array}$ & $\begin{array}{l}\text { Temporary } \\
\text { (165) }\end{array}$ & $\begin{array}{c}\text { Natural } \\
(764)\end{array}$ & $\begin{array}{l}\text { Restored } \\
\quad(426)\end{array}$ & $\begin{array}{l}\text { Private } \\
(610)\end{array}$ & $\begin{array}{l}\text { Federal } \\
(580)\end{array}$ \\
\hline Eastern Kingbird & EAKI & 0.215 & 0.432 & 0.766 & 0.239 & 0.173 & 0.030 & 0.243 & 0.164 & 0.152 & 0.281 \\
\hline Ruddy Duck & RUDU & 0.214 & 0.477 & 0.723 & 0.273 & 0.132 & 0.018 & 0.259 & 0.134 & 0.134 & 0.298 \\
\hline Marsh Wren & MAWR & 0.203 & 0.114 & 0.383 & 0.351 & 0.080 & 0.012 & 0.213 & 0.185 & 0.148 & 0.262 \\
\hline Song Sparrow & SOSP & 0.199 & 0.250 & 0.447 & 0.260 & 0.146 & 0.055 & 0.208 & 0.183 & 0.144 & 0.257 \\
\hline Redhead & REDH & 0.194 & 0.364 & 0.638 & 0.261 & 0.107 & 0.024 & 0.221 & 0.146 & 0.128 & 0.264 \\
\hline Bobolink & ВOBO & 0.182 & 0.159 & 0.383 & 0.195 & 0.166 & 0.127 & 0.177 & 0.190 & 0.175 & 0.188 \\
\hline Brown-headed Cowbird & BHCO & 0.177 & 0.591 & 0.511 & 0.181 & 0.137 & 0.061 & 0.194 & 0.148 & 0.149 & 0.207 \\
\hline Northern Pintail & NOPI & 0.176 & 0.477 & 0.213 & 0.160 & 0.190 & 0.103 & 0.170 & 0.188 & 0.177 & 0.176 \\
\hline Clay-colored Sparrow & CCSP & 0.149 & 0.318 & 0.489 & 0.132 & 0.105 & 0.170 & 0.147 & 0.153 & 0.121 & 0.178 \\
\hline Barn Swallow & BARS & 0.129 & 0.295 & 0.213 & 0.153 & 0.107 & 0.036 & 0.127 & 0.131 & 0.130 & 0.128 \\
\hline Green-winged Teal & AGWT & 0.118 & 0.409 & 0.298 & 0.111 & 0.107 & 0.042 & 0.140 & 0.080 & 0.082 & 0.157 \\
\hline Lesser Scaup & LESC & 0.113 & 0.568 & 0.532 & 0.103 & 0.073 & 0.006 & 0.137 & 0.070 & 0.059 & 0.171 \\
\hline Sedge Wren & SEWR & 0.107 & 0.114 & 0.234 & 0.107 & 0.093 & 0.103 & 0.097 & 0.124 & 0.097 & 0.117 \\
\hline Virginia Rail & VIRA & 0.102 & 0.045 & 0.191 & 0.168 & 0.044 & 0.024 & 0.098 & 0.108 & 0.082 & 0.122 \\
\hline Wilson's Phalarope & WIPH & 0.082 & 0.432 & 0.170 & 0.061 & 0.073 & 0.048 & 0.094 & 0.059 & 0.056 & 0.109 \\
\hline American Bittern & AMBI & 0.081 & 0.136 & 0.340 & 0.097 & 0.056 & 0.000 & 0.093 & 0.059 & 0.046 & 0.117 \\
\hline Willet & WILL & 0.066 & 0.432 & 0.298 & 0.046 & 0.044 & 0.018 & 0.081 & 0.038 & 0.051 & 0.081 \\
\hline Western Meadowlark & WEME & 0.063 & 0.318 & 0.319 & 0.034 & 0.051 & 0.042 & 0.071 & 0.049 & 0.062 & 0.064 \\
\hline
\end{tabular}




\begin{tabular}{|c|c|c|c|c|c|c|c|c|c|c|c|}
\hline \multirow{2}{*}{ Common name } & \multirow{2}{*}{$\begin{array}{l}\text { Alpha } \\
\text { code }\end{array}$} & \multirow{2}{*}{$\begin{array}{l}\text { Proportion } \\
\text { of } \\
\text { wetlands } \\
\text { surveyed } \\
\text { with } \\
\text { species } \\
\text { present } \\
(1,190)\end{array}$} & \multicolumn{5}{|c|}{$\begin{array}{l}\text { Proportion of wetlands surveyed } \\
\text { by wetland class with species present }\end{array}$} & \multicolumn{2}{|c|}{$\begin{array}{c}\text { Proportion of } \\
\text { wetlands surveyed } \\
\text { by wetland type with } \\
\text { species present }\end{array}$} & \multicolumn{2}{|c|}{$\begin{array}{l}\text { Proportion of } \\
\text { wetlands surveyed by } \\
\text { landowner group with } \\
\text { species present }\end{array}$} \\
\hline & & & $\begin{array}{l}\text { Alkali } \\
\text { (44) }\end{array}$ & $\begin{array}{l}\text { Permanent } \\
\quad(47)\end{array}$ & $\begin{array}{c}\text { Semiper- } \\
\text { manent } \\
(524)\end{array}$ & $\begin{array}{l}\text { Seasonal } \\
\quad(410)\end{array}$ & $\begin{array}{l}\text { Temporary } \\
\text { (165) }\end{array}$ & $\begin{array}{l}\text { Natural } \\
(764)\end{array}$ & $\begin{array}{l}\text { Restored } \\
\quad(426)\end{array}$ & $\begin{array}{l}\text { Private } \\
(610)\end{array}$ & $\begin{array}{l}\text { Federal } \\
(\mathbf{5 8 0 )}\end{array}$ \\
\hline $\begin{array}{l}\text { Black-crowned Night- } \\
\text { Heron }\end{array}$ & $\mathrm{BCNH}$ & 0.056 & 0.159 & 0.298 & 0.073 & 0.020 & 0.000 & 0.072 & 0.028 & 0.016 & 0.098 \\
\hline Western Kingbird & WEKI & 0.055 & 0.205 & 0.277 & 0.040 & 0.046 & 0.024 & 0.062 & 0.045 & 0.062 & 0.048 \\
\hline Mourning Dove & MODO & 0.054 & 0.114 & 0.191 & 0.046 & 0.056 & 0.018 & 0.059 & 0.045 & 0.044 & 0.064 \\
\hline Tree Swallow & TRES & 0.054 & 0.136 & 0.149 & 0.071 & 0.029 & 0.012 & 0.054 & 0.054 & 0.054 & 0.053 \\
\hline American Goldfinch & AMGO & 0.053 & 0.114 & 0.085 & 0.067 & 0.041 & 0.012 & 0.054 & 0.052 & 0.041 & 0.066 \\
\hline Canvasback & CANV & 0.053 & 0.227 & 0.362 & 0.046 & 0.027 & 0.006 & 0.065 & 0.031 & 0.028 & 0.079 \\
\hline Ring-necked Duck & RNDU & 0.053 & 0.068 & 0.298 & 0.073 & 0.020 & 0.000 & 0.064 & 0.033 & 0.036 & 0.071 \\
\hline Cliff Swallow & CLSW & 0.052 & 0.068 & 0.064 & 0.074 & 0.032 & 0.024 & 0.052 & 0.052 & 0.066 & 0.038 \\
\hline Wilson's Snipe & COSN & 0.050 & 0.091 & 0.043 & 0.078 & 0.017 & 0.036 & 0.060 & 0.033 & 0.043 & 0.059 \\
\hline Canada Goose & CAGO & 0.050 & 0.227 & 0.234 & 0.057 & 0.017 & 0.006 & 0.050 & 0.049 & 0.028 & 0.072 \\
\hline Yellow Warbler & YWAR & 0.050 & 0.159 & 0.191 & 0.055 & 0.029 & 0.012 & 0.055 & 0.040 & 0.031 & 0.069 \\
\hline American Wigeon & AMWI & 0.048 & 0.409 & 0.170 & 0.027 & 0.037 & 0.012 & 0.047 & 0.049 & 0.039 & 0.057 \\
\hline Ring-billed Gull & RBGU & 0.047 & 0.386 & 0.277 & 0.027 & 0.029 & 0.000 & 0.062 & 0.021 & 0.038 & 0.057 \\
\hline Eared Grebe & EAGR & 0.046 & 0.205 & 0.234 & 0.052 & 0.017 & 0.006 & 0.068 & 0.007 & 0.021 & 0.072 \\
\hline Upland Sandpiper & UPSA & 0.046 & 0.114 & 0.106 & 0.055 & 0.032 & 0.018 & 0.050 & 0.040 & 0.039 & 0.053 \\
\hline Le Conte's Sparrow & LCSP & 0.039 & 0.227 & 0.128 & 0.032 & 0.022 & 0.030 & 0.035 & 0.047 & 0.038 & 0.041 \\
\hline Franklin's Gull & FRGU & 0.037 & 0.182 & 0.085 & 0.034 & 0.027 & 0.018 & 0.047 & 0.019 & 0.031 & 0.043 \\
\hline Marbled Godwit & MAGO & 0.037 & 0.182 & 0.128 & 0.027 & 0.034 & 0.012 & 0.043 & 0.026 & 0.026 & 0.048 \\
\hline
\end{tabular}




\begin{tabular}{|c|c|c|c|c|c|c|c|c|c|c|c|}
\hline \multirow{2}{*}{ Common name } & \multirow{2}{*}{$\begin{array}{l}\text { Alpha } \\
\text { code }\end{array}$} & \multirow{2}{*}{$\begin{array}{c}\text { Proportion } \\
\text { of } \\
\text { wetlands } \\
\text { surveyed } \\
\text { with } \\
\text { species } \\
\text { present } \\
(1,190)\end{array}$} & \multicolumn{5}{|c|}{$\begin{array}{l}\text { Proportion of wetlands surveyed } \\
\text { by wetland class with species present }\end{array}$} & \multicolumn{2}{|c|}{$\begin{array}{l}\text { Proportion of } \\
\text { wetlands surveyed } \\
\text { by wetland type with } \\
\text { species present }\end{array}$} & \multicolumn{2}{|c|}{$\begin{array}{l}\text { Proportion of } \\
\text { wetlands surveyed by } \\
\text { landowner group with } \\
\text { species present }\end{array}$} \\
\hline & & & $\begin{array}{l}\text { Alkali } \\
(44)\end{array}$ & $\begin{array}{l}\text { Permanent } \\
\quad(47)\end{array}$ & $\begin{array}{c}\text { Semiper- } \\
\text { manent } \\
(524)\end{array}$ & $\begin{array}{l}\text { Seasonal } \\
(410)\end{array}$ & $\begin{array}{l}\text { Temporary } \\
\text { (165) }\end{array}$ & $\begin{array}{l}\text { Natural } \\
(764)\end{array}$ & $\begin{array}{l}\text { Restored } \\
\quad(426)\end{array}$ & $\begin{array}{l}\text { Private } \\
(610)\end{array}$ & $\begin{array}{l}\text { Federal } \\
(580)\end{array}$ \\
\hline Willow Flycatcher & WIFL & 0.033 & 0.114 & 0.191 & 0.032 & 0.015 & 0.012 & 0.042 & 0.016 & 0.013 & 0.053 \\
\hline Wood Duck & WODU & 0.033 & 0.045 & 0.043 & 0.052 & 0.020 & 0.000 & 0.034 & 0.031 & 0.018 & 0.048 \\
\hline Double-crested Cormorant & DCCO & 0.032 & 0.114 & 0.106 & 0.042 & 0.015 & 0.000 & 0.038 & 0.021 & 0.018 & 0.047 \\
\hline Grasshopper Sparrow & GRSP & 0.029 & 0.000 & 0.000 & 0.036 & 0.034 & 0.012 & 0.020 & 0.047 & 0.038 & 0.021 \\
\hline American White Pelican & AWPE & 0.029 & 0.023 & 0.128 & 0.040 & 0.012 & 0.006 & 0.027 & 0.031 & 0.021 & 0.036 \\
\hline Swamp Sparrow & SWSP & 0.025 & 0.000 & 0.021 & 0.044 & 0.012 & 0.006 & 0.026 & 0.023 & 0.023 & 0.028 \\
\hline American Avocet & AMAV & 0.024 & 0.341 & 0.106 & 0.006 & 0.015 & 0.000 & 0.027 & 0.019 & 0.020 & 0.029 \\
\hline Horned Grebe & HOGR & 0.024 & 0.250 & 0.128 & 0.011 & 0.010 & 0.006 & 0.030 & 0.012 & 0.016 & 0.031 \\
\hline Horned Lark & HOLA & 0.022 & 0.136 & 0.043 & 0.017 & 0.015 & 0.018 & 0.026 & 0.014 & 0.028 & 0.016 \\
\hline Ring-necked Pheasant & RPHE & 0.018 & 0.023 & 0.021 & 0.021 & 0.017 & 0.012 & 0.020 & 0.016 & 0.011 & 0.026 \\
\hline American Robin & AMRO & 0.018 & 0.000 & 0.043 & 0.017 & 0.022 & 0.006 & 0.018 & 0.016 & 0.015 & 0.021 \\
\hline House Wren & HOWR & 0.017 & 0.000 & 0.085 & 0.013 & 0.010 & 0.030 & 0.018 & 0.014 & 0.018 & 0.016 \\
\hline Nelson's Sparrow & NSTS & 0.017 & 0.114 & 0.064 & 0.010 & 0.010 & 0.018 & 0.018 & 0.014 & 0.015 & 0.019 \\
\hline Northern Harrier & NOHA & 0.017 & 0.068 & 0.064 & 0.015 & 0.005 & 0.024 & 0.020 & 0.012 & 0.013 & 0.021 \\
\hline Baltimore Oriole & BAOR & 0.015 & 0.023 & 0.085 & 0.013 & 0.015 & 0.000 & 0.016 & 0.014 & 0.015 & 0.016 \\
\hline $\begin{array}{l}\text { Chestnut-collared } \\
\text { Longspur }\end{array}$ & CCLO & 0.015 & 0.273 & 0.000 & 0.004 & 0.005 & 0.012 & 0.017 & 0.012 & 0.018 & 0.012 \\
\hline Gray Catbird & GRCA & 0.014 & 0.045 & 0.128 & 0.013 & 0.005 & 0.000 & 0.018 & 0.007 & 0.008 & 0.021 \\
\hline Northern Flicker & NOFL & 0.014 & 0.068 & 0.021 & 0.015 & 0.010 & 0.006 & 0.016 & 0.012 & 0.015 & 0.014 \\
\hline
\end{tabular}




\begin{tabular}{|c|c|c|c|c|c|c|c|c|c|c|c|}
\hline \multirow{2}{*}{ Common name } & \multirow{2}{*}{$\begin{array}{l}\text { Alpha } \\
\text { code }\end{array}$} & \multirow{2}{*}{$\begin{array}{c}\text { Proportion } \\
\text { of } \\
\text { wetlands } \\
\text { surveyed } \\
\text { with } \\
\text { species } \\
\text { present } \\
(1,190)\end{array}$} & \multicolumn{5}{|c|}{$\begin{array}{l}\text { Proportion of wetlands surveyed } \\
\text { by wetland class with species present }\end{array}$} & \multicolumn{2}{|c|}{$\begin{array}{l}\text { Proportion of } \\
\text { wetlands surveyed } \\
\text { by wetland type with } \\
\text { species present }\end{array}$} & \multicolumn{2}{|c|}{$\begin{array}{l}\text { Proportion of } \\
\text { wetlands surveyed by } \\
\text { landowner group with } \\
\text { species present }\end{array}$} \\
\hline & & & $\begin{array}{l}\text { Alkali } \\
(44)\end{array}$ & $\begin{array}{l}\text { Permanent } \\
\quad(47)\end{array}$ & $\begin{array}{c}\text { Semiper- } \\
\text { manent } \\
(524)\end{array}$ & $\begin{array}{l}\text { Seasonal } \\
(410)\end{array}$ & $\begin{array}{l}\text { Temporary } \\
\text { (165) }\end{array}$ & $\begin{array}{l}\text { Natural } \\
(764)\end{array}$ & $\begin{array}{l}\text { Restored } \\
\quad(426)\end{array}$ & $\begin{array}{l}\text { Private } \\
(610)\end{array}$ & $\begin{array}{l}\text { Federal } \\
(580)\end{array}$ \\
\hline Orchard Oriole & OROR & 0.013 & 0.023 & 0.021 & 0.017 & 0.007 & 0.012 & 0.017 & 0.007 & 0.007 & 0.021 \\
\hline Bank Swallow & BANS & 0.013 & 0.045 & 0.064 & 0.011 & 0.010 & 0.000 & 0.010 & 0.016 & 0.011 & 0.014 \\
\hline Baird's Sparrow & BAIS & 0.012 & 0.068 & 0.021 & 0.002 & 0.015 & 0.018 & 0.013 & 0.009 & 0.013 & 0.010 \\
\hline Western Grebe & WEGR & 0.011 & 0.091 & 0.085 & 0.008 & 0.002 & 0.000 & 0.017 & 0.000 & 0.005 & 0.017 \\
\hline Great Blue Heron & GTBH & 0.010 & 0.045 & 0.021 & 0.015 & 0.002 & 0.000 & 0.012 & 0.007 & 0.003 & 0.017 \\
\hline Least Flycatcher & LEFL & 0.010 & 0.000 & 0.043 & 0.010 & 0.010 & 0.006 & 0.010 & 0.009 & 0.011 & 0.009 \\
\hline Bufflehead & BUFF & 0.009 & 0.091 & 0.106 & 0.004 & 0.000 & 0.000 & 0.013 & 0.002 & 0.000 & 0.019 \\
\hline California Gull & CAGU & 0.009 & 0.091 & 0.064 & 0.004 & 0.005 & 0.000 & 0.012 & 0.005 & 0.007 & 0.012 \\
\hline Dickcissel & DICK & 0.009 & 0.000 & 0.000 & 0.011 & 0.007 & 0.012 & 0.007 & 0.014 & 0.010 & 0.009 \\
\hline Red-tailed Hawk & RTHA & 0.009 & 0.023 & 0.043 & 0.010 & 0.005 & 0.006 & 0.012 & 0.005 & 0.003 & 0.016 \\
\hline Great Horned Owl & GHOW & 0.008 & 0.000 & 0.064 & 0.011 & 0.002 & 0.000 & 0.010 & 0.005 & 0.005 & 0.012 \\
\hline $\begin{array}{l}\text { Northern Rough-winged } \\
\text { Swallow }\end{array}$ & NRWS & 0.008 & 0.000 & 0.000 & 0.013 & 0.005 & 0.006 & 0.007 & 0.012 & 0.010 & 0.007 \\
\hline Piping Plover & PIPL & 0.008 & 0.182 & 0.021 & 0.000 & 0.002 & 0.000 & 0.009 & 0.007 & 0.003 & 0.014 \\
\hline Brown Thrasher & BRTH & 0.008 & 0.023 & 0.021 & 0.008 & 0.007 & 0.000 & 0.012 & 0.000 & 0.008 & 0.007 \\
\hline Lesser Yellowlegs & LEYE & 0.008 & 0.000 & 0.000 & 0.011 & 0.005 & 0.006 & 0.010 & 0.002 & 0.005 & 0.010 \\
\hline Warbling Vireo & WAVI & 0.008 & 0.000 & 0.021 & 0.010 & 0.002 & 0.012 & 0.009 & 0.005 & 0.005 & 0.010 \\
\hline Cattle Egret & CAEG & 0.006 & 0.000 & 0.000 & 0.010 & 0.005 & 0.000 & 0.007 & 0.005 & 0.005 & 0.007 \\
\hline Forster's Tern & FOTE & 0.006 & 0.045 & 0.021 & 0.006 & 0.002 & 0.000 & 0.005 & 0.007 & 0.002 & 0.010 \\
\hline
\end{tabular}




\begin{tabular}{|c|c|c|c|c|c|c|c|c|c|c|c|}
\hline \multirow{2}{*}{ Common name } & \multirow{2}{*}{$\begin{array}{l}\text { Alpha } \\
\text { code }\end{array}$} & \multirow{2}{*}{$\begin{array}{l}\text { Proportion } \\
\text { of } \\
\text { wetlands } \\
\text { surveyed } \\
\text { with } \\
\text { species } \\
\text { present } \\
(1,190)\end{array}$} & \multicolumn{5}{|c|}{$\begin{array}{l}\text { Proportion of wetlands surveyed } \\
\text { by wetland class with species present }\end{array}$} & \multicolumn{2}{|c|}{$\begin{array}{l}\text { Proportion of } \\
\text { wetlands surveyed } \\
\text { by wetland type with } \\
\text { species present }\end{array}$} & \multicolumn{2}{|c|}{$\begin{array}{l}\text { Proportion of } \\
\text { wetlands surveyed by } \\
\text { landowner group with } \\
\text { species present }\end{array}$} \\
\hline & & & $\begin{array}{l}\text { Alkali } \\
\text { (44) }\end{array}$ & $\begin{array}{l}\text { Permanent } \\
\quad(47)\end{array}$ & $\begin{array}{c}\text { Semiper- } \\
\text { manent } \\
(524)\end{array}$ & $\begin{array}{l}\text { Seasonal } \\
\quad(410)\end{array}$ & $\begin{array}{l}\text { Temporary } \\
\text { (165) }\end{array}$ & $\begin{array}{c}\text { Natural } \\
(764)\end{array}$ & $\begin{array}{l}\text { Restored } \\
\quad(426)\end{array}$ & $\begin{array}{l}\text { Private } \\
(610)\end{array}$ & $\begin{array}{l}\text { Federal } \\
(580)\end{array}$ \\
\hline Cedar Waxwing & CEDW & 0.005 & 0.023 & 0.021 & 0.004 & 0.005 & 0.000 & 0.008 & 0.000 & 0.003 & 0.007 \\
\hline Red-necked Grebe & RNGR & 0.005 & 0.023 & 0.064 & 0.004 & 0.000 & 0.000 & 0.007 & 0.002 & 0.002 & 0.009 \\
\hline Vesper Sparrow & VESP & 0.005 & 0.000 & 0.021 & 0.002 & 0.005 & 0.012 & 0.008 & 0.000 & 0.003 & 0.007 \\
\hline Great Egret & GREG & 0.004 & 0.000 & 0.021 & 0.004 & 0.002 & 0.006 & 0.003 & 0.007 & 0.003 & 0.005 \\
\hline Hooded Merganser & HOME & 0.004 & 0.091 & 0.021 & 0.000 & 0.000 & 0.000 & 0.007 & 0.000 & 0.002 & 0.007 \\
\hline Least Sandpiper & LESA & 0.004 & 0.068 & 0.021 & 0.002 & 0.000 & 0.000 & 0.005 & 0.002 & 0.002 & 0.007 \\
\hline Short-eared Owl & SEOW & 0.004 & 0.023 & 0.000 & 0.000 & 0.005 & 0.012 & 0.004 & 0.005 & 0.003 & 0.005 \\
\hline Bullock's Oriole & BUOR & 0.003 & 0.023 & 0.000 & 0.000 & 0.005 & 0.006 & 0.003 & 0.005 & 0.005 & 0.002 \\
\hline Spotted Sandpiper & SPSA & 0.003 & 0.091 & 0.000 & 0.000 & 0.000 & 0.000 & 0.005 & 0.000 & 0.000 & 0.007 \\
\hline American Redstart & AMRE & 0.003 & 0.000 & 0.000 & 0.002 & 0.002 & 0.006 & 0.003 & 0.002 & 0.003 & 0.002 \\
\hline Common Nighthawk & CONI & 0.003 & 0.023 & 0.000 & 0.004 & 0.000 & 0.000 & 0.003 & 0.002 & 0.002 & 0.003 \\
\hline Gray Partridge & GRPA & 0.003 & 0.000 & 0.000 & 0.002 & 0.002 & 0.006 & 0.001 & 0.005 & 0.003 & 0.002 \\
\hline Greater Yellowlegs & GRYE & 0.003 & 0.000 & 0.021 & 0.002 & 0.002 & 0.000 & 0.003 & 0.002 & 0.003 & 0.002 \\
\hline House Sparrow & HOSP & 0.003 & 0.000 & 0.043 & 0.002 & 0.000 & 0.000 & 0.004 & 0.000 & 0.002 & 0.003 \\
\hline Least Bittern & LEBI & 0.003 & 0.000 & 0.000 & 0.006 & 0.000 & 0.000 & 0.003 & 0.002 & 0.002 & 0.003 \\
\hline Swainson's Hawk & SWHA & 0.003 & 0.000 & 0.021 & 0.002 & 0.002 & 0.000 & 0.003 & 0.002 & 0.002 & 0.003 \\
\hline American Crow & AMCR & 0.002 & 0.000 & 0.021 & 0.000 & 0.002 & 0.000 & 0.000 & 0.005 & 0.002 & 0.002 \\
\hline Downy Woodpecker & DOWO & 0.002 & 0.000 & 0.021 & 0.000 & 0.002 & 0.000 & 0.003 & 0.000 & 0.002 & 0.002 \\
\hline
\end{tabular}




\begin{tabular}{|c|c|c|c|c|c|c|c|c|c|c|c|}
\hline \multirow{2}{*}{ Common name } & \multirow{2}{*}{$\begin{array}{l}\text { Alpha } \\
\text { code }\end{array}$} & \multirow{2}{*}{$\begin{array}{l}\text { Proportion } \\
\text { of } \\
\text { wetlands } \\
\text { surveyed } \\
\text { with } \\
\text { species } \\
\text { present } \\
(1,190)\end{array}$} & \multicolumn{5}{|c|}{$\begin{array}{l}\text { Proportion of wetlands surveyed } \\
\text { by wetland class with species present }\end{array}$} & \multicolumn{2}{|c|}{$\begin{array}{c}\text { Proportion of } \\
\text { wetlands surveyed } \\
\text { by wetland type with } \\
\text { species present }\end{array}$} & \multicolumn{2}{|c|}{$\begin{array}{c}\text { Proportion of } \\
\text { wetlands surveyed by } \\
\text { landowner group with } \\
\text { species present }\end{array}$} \\
\hline & & & $\begin{array}{l}\text { Alkali } \\
\text { (44) }\end{array}$ & $\begin{array}{l}\text { Permanent } \\
\quad(47)\end{array}$ & $\begin{array}{c}\text { Semiper- } \\
\text { manent } \\
(524)\end{array}$ & $\begin{array}{l}\text { Seasonal } \\
\quad(410)\end{array}$ & $\begin{array}{l}\text { Temporary } \\
\text { (165) }\end{array}$ & $\begin{array}{l}\text { Natural } \\
(764)\end{array}$ & $\begin{array}{l}\text { Restored } \\
\quad(426)\end{array}$ & $\begin{array}{l}\text { Private } \\
(610)\end{array}$ & $\begin{array}{l}\text { Federal } \\
(580)\end{array}$ \\
\hline Red-eyed Vireo & REVI & 0.002 & 0.000 & 0.000 & 0.000 & 0.005 & 0.000 & 0.001 & 0.002 & 0.003 & 0.000 \\
\hline White-faced Ibis & WFIB & 0.002 & 0.000 & 0.000 & 0.004 & 0.000 & 0.000 & 0.003 & 0.000 & 0.000 & 0.003 \\
\hline White-rumped Sandpiper & WRSA & 0.002 & 0.023 & 0.000 & 0.000 & 0.002 & 0.000 & 0.003 & 0.000 & 0.002 & 0.002 \\
\hline Yellow-rumped Warbler & YRWA & 0.002 & 0.000 & 0.043 & 0.000 & 0.000 & 0.000 & 0.003 & 0.000 & 0.000 & 0.003 \\
\hline Belted Kingfisher & BEKI & 0.001 & 0.000 & 0.000 & 0.002 & 0.000 & 0.000 & 0.001 & 0.000 & 0.000 & 0.002 \\
\hline Blackpoll Warbler & BLPW & 0.001 & 0.000 & 0.000 & 0.000 & 0.002 & 0.000 & 0.000 & 0.002 & 0.002 & 0.000 \\
\hline Brewer's Blackbird & BRBL & 0.001 & 0.000 & 0.000 & 0.000 & 0.002 & 0.000 & 0.000 & 0.002 & 0.002 & 0.000 \\
\hline Canada Warbler & CAWA & 0.001 & 0.000 & 0.000 & 0.002 & 0.000 & 0.000 & 0.001 & 0.000 & 0.000 & 0.002 \\
\hline Chipping Sparrow & CHSP & 0.001 & 0.000 & 0.021 & 0.000 & 0.000 & 0.000 & 0.001 & 0.000 & 0.000 & 0.002 \\
\hline Common Goldeneye & COGO & 0.001 & 0.000 & 0.021 & 0.000 & 0.000 & 0.000 & 0.001 & 0.000 & 0.000 & 0.002 \\
\hline Common Tern & COTE & 0.001 & 0.000 & 0.000 & 0.002 & 0.000 & 0.000 & 0.001 & 0.000 & 0.000 & 0.002 \\
\hline Eastern Bluebird & EABL & 0.001 & 0.000 & 0.000 & 0.002 & 0.000 & 0.000 & 0.001 & 0.000 & 0.000 & 0.002 \\
\hline Eastern Wood Pewee & EAWP & 0.001 & 0.000 & 0.000 & 0.002 & 0.000 & 0.000 & 0.001 & 0.000 & 0.000 & 0.002 \\
\hline Ferruginous Hawk & FEHA & 0.001 & 0.000 & 0.021 & 0.000 & 0.000 & 0.000 & 0.001 & 0.000 & 0.002 & 0.000 \\
\hline Great Crested Flycatcher & GCFL & 0.001 & 0.000 & 0.000 & 0.000 & 0.000 & 0.006 & 0.001 & 0.000 & 0.002 & 0.000 \\
\hline Great-tailed Grackle & GTGR & 0.001 & 0.000 & 0.000 & 0.002 & 0.000 & 0.000 & 0.001 & 0.000 & 0.000 & 0.002 \\
\hline Lark Sparrow & LASP & 0.001 & 0.023 & 0.000 & 0.000 & 0.000 & 0.000 & 0.000 & 0.002 & 0.002 & 0.000 \\
\hline Purple Martin & PUMA & 0.001 & 0.000 & 0.000 & 0.000 & 0.000 & 0.006 & 0.001 & 0.000 & 0.000 & 0.002 \\
\hline
\end{tabular}




\begin{tabular}{|c|c|c|c|c|c|c|c|c|c|c|c|}
\hline \multirow{2}{*}{ Common name } & \multirow{2}{*}{$\begin{array}{l}\text { Alpha } \\
\text { code }\end{array}$} & \multirow{2}{*}{$\begin{array}{c}\text { Proportion } \\
\text { of } \\
\text { wetlands } \\
\text { surveyed } \\
\text { with } \\
\text { species } \\
\text { present } \\
(1,190)\end{array}$} & \multicolumn{5}{|c|}{$\begin{array}{l}\text { Proportion of wetlands surveyed } \\
\text { by wetland class with species present }\end{array}$} & \multicolumn{2}{|c|}{$\begin{array}{c}\text { Proportion of } \\
\text { wetlands surveyed } \\
\text { by wetland type with } \\
\text { species present }\end{array}$} & \multicolumn{2}{|c|}{$\begin{array}{c}\text { Proportion of } \\
\text { wetlands surveyed by } \\
\text { landowner group with } \\
\text { species present }\end{array}$} \\
\hline & & & $\begin{array}{c}\text { Alkali } \\
(44)\end{array}$ & $\begin{array}{l}\text { Permanent } \\
\quad(47)\end{array}$ & $\begin{array}{l}\text { Semiper- } \\
\text { manent } \\
(524)\end{array}$ & $\begin{array}{l}\text { Seasonal } \\
(410)\end{array}$ & $\begin{array}{l}\text { Temporary } \\
(165)\end{array}$ & $\begin{array}{l}\text { Natural } \\
(764)\end{array}$ & $\begin{array}{l}\text { Restored } \\
\quad(426)\end{array}$ & $\begin{array}{l}\text { Private } \\
(610)\end{array}$ & $\begin{array}{l}\text { Federal } \\
(580)\end{array}$ \\
\hline Rock Pigeon & RODO & 0.001 & 0.000 & 0.000 & 0.000 & 0.002 & 0.000 & 0.000 & 0.002 & 0.002 & 0.000 \\
\hline Semipalmated Sandpiper & SESA & 0.001 & 0.000 & 0.000 & 0.000 & 0.000 & 0.006 & 0.001 & 0.000 & 0.000 & 0.002 \\
\hline Sharp-tailed Grouse & STGR & 0.001 & 0.000 & 0.000 & 0.002 & 0.000 & 0.000 & 0.000 & 0.002 & 0.002 & 0.000 \\
\hline Snow Goose & SNGO & 0.001 & 0.000 & 0.021 & 0.000 & 0.000 & 0.000 & 0.001 & 0.000 & 0.000 & 0.002 \\
\hline Snowy Egret & SNEG & 0.001 & 0.000 & 0.000 & 0.002 & 0.000 & 0.000 & 0.000 & 0.002 & 0.000 & 0.002 \\
\hline Sprague’s Pipit & SPPI & 0.001 & 0.023 & 0.000 & 0.000 & 0.000 & 0.000 & 0.001 & 0.000 & 0.000 & 0.002 \\
\hline Tennessee Warbler & TEWA & 0.001 & 0.023 & 0.000 & 0.000 & 0.000 & 0.000 & 0.001 & 0.000 & 0.000 & 0.002 \\
\hline Veery & VEER & 0.001 & 0.000 & 0.000 & 0.002 & 0.000 & 0.000 & 0.000 & 0.002 & 0.002 & 0.000 \\
\hline White Ibis & WHIB & 0.001 & 0.000 & 0.000 & 0.002 & 0.000 & 0.000 & 0.001 & 0.000 & 0.000 & 0.002 \\
\hline Wilson's Warbler & WIWA & 0.001 & 0.000 & 0.000 & 0.002 & 0.000 & 0.000 & 0.001 & 0.000 & 0.000 & 0.002 \\
\hline Wood Thrush & WOTH & 0.001 & 0.000 & 0.000 & 0.000 & 0.002 & 0.000 & 0.000 & 0.002 & 0.002 & 0.000 \\
\hline
\end{tabular}


Table 1-3. Summary of wetland- and landscape-level variables overall and by wetland class (alkali, permanent, semipermanent, seasonal, or temporary), wetland type (natural or restored), and landowner group (private or Federal), including mean, standard error, and range, in the Prairie Pothole Region of North and South Dakota in 1995-97.

[The numbers within parentheses in the column headings indicate the number of wetlands in each category. In each cell, the first number is the mean value, the number within parentheses is the standard error, and the range is from the minimum to maximum values.]

\begin{tabular}{|c|c|c|c|c|c|c|c|c|c|c|}
\hline \multirow[b]{2}{*}{ Variable } & \multirow[b]{2}{*}{$\begin{array}{l}\text { Overall } \\
(1,190)\end{array}$} & \multicolumn{5}{|c|}{ Wetland class } & \multicolumn{2}{|c|}{ Landowner group } & \multicolumn{2}{|c|}{ Wetland type } \\
\hline & & $\begin{array}{c}\text { Alkali } \\
(44)\end{array}$ & $\begin{array}{l}\text { Permanent } \\
\text { (47) }\end{array}$ & $\begin{array}{l}\text { Semiperm- } \\
\text { anent } \\
(524)\end{array}$ & $\begin{array}{l}\text { Seasonal } \\
(410)\end{array}$ & $\begin{array}{l}\text { Temporary } \\
\text { (165) }\end{array}$ & $\begin{array}{l}\text { Private } \\
(610)\end{array}$ & $\begin{array}{l}\text { Federal } \\
(580)\end{array}$ & $\begin{array}{c}\text { Natural } \\
\text { (764) }\end{array}$ & $\begin{array}{l}\text { Restored } \\
\quad(426)\end{array}$ \\
\hline \multicolumn{11}{|c|}{ Wetland-level variables } \\
\hline $\begin{array}{c}\text { Wetland size } \\
\text { (hectares) }\end{array}$ & $\begin{array}{r}4.02(0.36) \\
0.01-204.26\end{array}$ & $\begin{array}{l}26.56(5.85) \\
0.39-204.26\end{array}$ & $\begin{array}{l}23.60(3.83) \\
0.30-130.00\end{array}$ & $\begin{array}{l}3.58(0.39) \\
0.03-72.00\end{array}$ & $\begin{array}{l}1.36(0.17) \\
0.01-32.00\end{array}$ & $\begin{array}{r}0.47(0.07) \\
0.01-6.36\end{array}$ & $\begin{array}{r}5.30(0.54) \\
0.01-204.26\end{array}$ & $\begin{array}{r}1.72(0.25) \\
0.01-64.0\end{array}$ & $\begin{array}{l}2.00(0.30) \\
0.01-72.00\end{array}$ & $\begin{array}{r}6.15(0.67) \\
0.01-204.26\end{array}$ \\
\hline $\begin{array}{l}\text { Percentage of } \\
\text { the wetland } \\
\text { in open } \\
\text { water }\end{array}$ & $\begin{array}{c}37.38(0.91) \\
0-100\end{array}$ & $\begin{array}{c}64.61(4.23) \\
0-100\end{array}$ & $\begin{array}{c}62.55(3.15) \\
0-95\end{array}$ & $\begin{array}{c}42.71(1.31) \\
0-98\end{array}$ & $\begin{array}{c}33.17(1.53) \\
0-95\end{array}$ & $\begin{array}{c}16.48(1.94) \\
0-95\end{array}$ & $\begin{array}{c}41.95(1.15) \\
0-100\end{array}$ & $\begin{array}{c}29.19(1.41) \\
0-95\end{array}$ & $\begin{array}{c}28.45(1.14) \\
0-100\end{array}$ & $\begin{array}{c}46.78(1.33) \\
0-100\end{array}$ \\
\hline $\begin{array}{l}\text { Percentage of } \\
\text { the wetland } \\
\text { in emergent } \\
\text { vegetation }\end{array}$ & $\begin{array}{c}24.84(0.81) \\
0-100\end{array}$ & $\begin{array}{c}12.16(3.00) \\
0-85\end{array}$ & $\begin{array}{c}20.30(2.57) \\
0-95\end{array}$ & $\begin{array}{c}32.35(1.13) \\
0-100\end{array}$ & $\begin{array}{c}20.31(1.43) \\
0-100\end{array}$ & $\begin{array}{c}16.96(2.33) \\
0-100\end{array}$ & $\begin{array}{c}22.86(0.96) \\
0-100\end{array}$ & $\begin{array}{c}28.41(1.44) \\
0-100\end{array}$ & $\begin{array}{c}25.49(1.17) \\
0-100\end{array}$ & $\begin{array}{c}24.17(1.11) \\
0-100\end{array}$ \\
\hline $\begin{array}{l}\text { Percentage of } \\
\text { the wetland } \\
\text { in wet } \\
\text { meadow }\end{array}$ & $\begin{array}{c}33.63(0.96) \\
0-100\end{array}$ & $\begin{array}{c}14.86(2.75) \\
0-90\end{array}$ & $\begin{array}{c}12.30(1.61) \\
0-40\end{array}$ & $\begin{array}{c}23.08(1.01) \\
0-100\end{array}$ & $\begin{array}{c}43.14(1.77) \\
0-100\end{array}$ & $\begin{array}{c}54.57(3.15) \\
0-100\end{array}$ & $\begin{array}{c}30.68(1.15) \\
0-100\end{array}$ & $\begin{array}{c}38.91(1.67) \\
0-100\end{array}$ & $\begin{array}{c}40.66(1.39) \\
0-100\end{array}$ & $\begin{array}{c}26.23(1.23) \\
0-100\end{array}$ \\
\hline $\begin{array}{l}\text { Percentage of } \\
\text { the wetland } \\
\text { in } \\
\text { shoreline/ } \\
\text { mudflat }\end{array}$ & $\begin{array}{c}3.61(0.32) \\
0-100\end{array}$ & $\begin{array}{c}8.36(1.23) \\
0-30\end{array}$ & $\begin{array}{l}4.85(0.65) \\
0-15\end{array}$ & $\begin{array}{l}1.88(0.25) \\
0-90\end{array}$ & $\begin{array}{l}3.26(0.45) \\
0-95\end{array}$ & $\begin{array}{c}8.38(1.73) \\
0-100\end{array}$ & $\begin{array}{c}3.93(0.42) \\
0-100\end{array}$ & $\begin{array}{c}3.04(0.46) \\
0-100\end{array}$ & $\begin{array}{c}4.86(0.57) \\
0-100\end{array}$ & $\begin{array}{l}2.30(0.24) \\
0-50\end{array}$ \\
\hline
\end{tabular}




\begin{tabular}{|c|c|c|c|c|c|c|c|c|c|c|}
\hline \multirow[b]{2}{*}{ Variable } & \multirow[b]{2}{*}{$\begin{array}{l}\text { Overall } \\
(1,190)\end{array}$} & \multicolumn{5}{|c|}{ Wetland class } & \multicolumn{2}{|c|}{ Landowner group } & \multicolumn{2}{|c|}{ Wetland type } \\
\hline & & $\begin{array}{l}\text { Alkali } \\
(44)\end{array}$ & $\begin{array}{l}\text { Permanent } \\
\text { (47) }\end{array}$ & $\begin{array}{l}\text { Semiperm- } \\
\text { anent } \\
(524)\end{array}$ & $\begin{array}{l}\text { Seasonal } \\
(410)\end{array}$ & $\begin{array}{l}\text { Temporary } \\
\text { (165) }\end{array}$ & $\begin{array}{l}\text { Private } \\
(610)\end{array}$ & $\begin{array}{c}\text { Federal } \\
(580)\end{array}$ & $\begin{array}{c}\text { Natural } \\
\text { (764) }\end{array}$ & $\begin{array}{l}\text { Restored } \\
\quad(426)\end{array}$ \\
\hline \multicolumn{11}{|c|}{ Landscape-level variables } \\
\hline $\begin{array}{l}\text { Percentage of } \\
\text { grassland } \\
\text { area within } \\
800 \text { meters }\end{array}$ & $\begin{array}{c}56.31(0.65) \\
0-100\end{array}$ & $\begin{array}{c}55.16(3.41) \\
9-84\end{array}$ & $\begin{array}{l}56.00(3.08) \\
14-92\end{array}$ & $\begin{array}{c}55.48(0.99) \\
0-97\end{array}$ & $\begin{array}{c}57.68(1.09) \\
0-92\end{array}$ & $\begin{array}{c}55.97(1.88) \\
0-97\end{array}$ & $\begin{array}{c}55.37(0.85) \\
0-97\end{array}$ & $\begin{array}{l}58.00(1.02) \\
5-96\end{array}$ & $\begin{array}{c}55.05(0.94) \\
0-97\end{array}$ & $\begin{array}{c}57.64(0.90) \\
5-92\end{array}$ \\
\hline $\begin{array}{c}\text { Percentage of } \\
\text { agricultural } \\
\text { area within } \\
800 \text { meters }\end{array}$ & $\begin{array}{c}23.56(0.64) \\
0-90\end{array}$ & $\begin{array}{c}16.93(3.42) \\
0-85\end{array}$ & $\begin{array}{l}20.68(2.84) \\
0-63\end{array}$ & $\begin{array}{c}23.50(0.96) \\
0-84\end{array}$ & $\begin{array}{c}23.50(1.06) \\
0-90\end{array}$ & $\begin{array}{c}26.52(1.87) \\
0-88\end{array}$ & $\begin{array}{c}23.27(0.82) \\
0-90\end{array}$ & $\begin{array}{l}24.08(1.00) \\
0-84\end{array}$ & $\begin{array}{c}28.16(0.95) \\
0-90\end{array}$ & $\begin{array}{c}18.72(0.81) \\
0-84\end{array}$ \\
\hline $\begin{array}{l}\text { Percentage of } \\
\text { wetland } \\
\text { area within } \\
800 \text { meters }\end{array}$ & $\begin{array}{c}14.44(0.29) \\
0-82\end{array}$ & $\begin{array}{c}22.16(2.20) \\
0-68\end{array}$ & $\begin{array}{l}18.81(2.04) \\
3-82\end{array}$ & $\begin{array}{c}15.23(0.42) \\
0-77\end{array}$ & $\begin{array}{c}13.20(0.40) \\
0-63\end{array}$ & $\begin{array}{c}11.72(0.79) \\
0-81\end{array}$ & $\begin{array}{c}16.02(0.38) \\
0-82\end{array}$ & $\begin{array}{c}11.61(0.39) \\
0-63\end{array}$ & $\begin{array}{c}11.02(0.31) \\
0-54\end{array}$ & $\begin{array}{c}18.03(0.44) \\
0-82\end{array}$ \\
\hline $\begin{array}{l}\text { Number of } \\
\text { wetlands } \\
\text { within } 800 \\
\text { meters }\end{array}$ & $\begin{array}{c}27.52(0.39) \\
1-75\end{array}$ & $\begin{array}{c}14.591 .64) \\
1-54\end{array}$ & $\begin{array}{c}18.81(1.46) \\
1-57\end{array}$ & $\begin{array}{c}28.49(0.59) \\
3-75\end{array}$ & $\begin{array}{c}27.71(0.58) \\
1-66\end{array}$ & $\begin{array}{c}29.89(1.13) \\
3-74\end{array}$ & $\begin{array}{c}27.97(0.48) \\
1-75\end{array}$ & $\begin{array}{l}26.71(0.64) \\
2-68\end{array}$ & $\begin{array}{c}29.28(0.56) \\
1-75\end{array}$ & $\begin{array}{c}25.67(0.51) \\
1-68\end{array}$ \\
\hline
\end{tabular}


Table 1-4. Summary of wetland- and landscape-level variables for each species, including mean, standard error, and range, in the Prairie Pothole Region of North and South Dakota in 1995-97.

[Only wetlands in which the species was observed were used to compute these summaries. In each cell, the first number is the mean value, the number within parentheses is the standard error, and the range is from the minimum to maximum value. $\mathrm{m}$, meters; $(-)$, no standard error because sample size equals one]

\begin{tabular}{|c|c|c|c|c|c|c|c|c|c|c|c|}
\hline \multirow[b]{2}{*}{ Common name } & \multirow{2}{*}{$\begin{array}{l}\text { Number } \\
\text { of } \\
\text { wetlands } \\
\text { with } \\
\text { species } \\
\text { present }\end{array}$} & \multirow{2}{*}{$\begin{array}{c}\text { Proportion } \\
\text { of } \\
\text { wetlands } \\
\text { with } \\
\text { species } \\
\text { present }\end{array}$} & \multicolumn{5}{|c|}{ Wetland-level variables } & \multicolumn{4}{|c|}{ Landscape-level variables } \\
\hline & & & $\begin{array}{l}\text { Wetland size } \\
\text { (hectares) }\end{array}$ & $\begin{array}{l}\text { Percentage of } \\
\text { wetland in } \\
\text { open water }\end{array}$ & $\begin{array}{l}\text { Percentage of } \\
\text { the wetland in } \\
\text { emergent } \\
\text { vegetation }\end{array}$ & $\begin{array}{l}\text { Percentage of } \\
\text { the wetland in } \\
\text { wet meadow }\end{array}$ & $\begin{array}{l}\text { Percentage } \\
\text { of the } \\
\text { wetland in } \\
\text { shorelinel } \\
\text { mudflat }\end{array}$ & $\begin{array}{l}\text { Percentage of } \\
\text { grassland } \\
\text { area within } \\
800 \mathrm{~m}\end{array}$ & $\begin{array}{l}\text { Percentage of } \\
\text { agricultural } \\
\text { area within } \\
800 \mathrm{~m}\end{array}$ & $\begin{array}{l}\text { Percentage } \\
\text { of wetland } \\
\text { area within } \\
\quad 800 \mathrm{~m}\end{array}$ & $\begin{array}{c}\text { Number of } \\
\text { wetlands } \\
\text { within } 800 \mathrm{~m}\end{array}$ \\
\hline $\begin{array}{l}\text { Red-winged } \\
\text { Blackbird }\end{array}$ & 944 & 0.793 & $\begin{array}{c}4.37(0.38) \\
0.01-130\end{array}$ & $\begin{array}{c}39.33(1.01) \\
0-100\end{array}$ & $\begin{array}{c}26.62(0.91) \\
0-100\end{array}$ & $\begin{array}{c}31.48(1.02) \\
0-100\end{array}$ & $\begin{array}{l}2.44(0.24) \\
0-95\end{array}$ & $\begin{array}{c}57.01(0.73) \\
1-97\end{array}$ & $\begin{array}{l}22.33(0.7) \\
0-90\end{array}$ & $\begin{array}{c}14.92(0.33) \\
0-82\end{array}$ & $\begin{array}{c}27.28(0.42) \\
1-75\end{array}$ \\
\hline Blue-winged Teal & 851 & 0.715 & $\begin{array}{r}5.39(0.5) \\
0.01-204.26\end{array}$ & $\begin{array}{l}43.41(1.04) \\
0-100\end{array}$ & $\begin{array}{l}24.73(0.9) \\
0-100\end{array}$ & $\begin{array}{c}29.03(1) \\
0-100\end{array}$ & $\begin{array}{l}2.82(0.26) \\
0-95\end{array}$ & $\begin{array}{c}56.45(0.76) \\
2-97\end{array}$ & $\begin{array}{c}22.78(0.72) \\
0-89\end{array}$ & $\begin{array}{c}15.03(0.34) \\
0-82\end{array}$ & $\begin{array}{c}26.82(0.46) \\
1-75\end{array}$ \\
\hline Mallard & 601 & 0.505 & $\begin{array}{l}6.9(0.61) \\
0.01-130\end{array}$ & $\begin{array}{c}46.84(1.25) \\
0-100\end{array}$ & $\begin{array}{c}24.24(1.05) \\
0-100\end{array}$ & $\begin{array}{c}26(1.15) \\
0-100\end{array}$ & $\begin{array}{l}2.9(0.31) \\
0-95\end{array}$ & $\begin{array}{l}57.09(0.9) \\
3-97\end{array}$ & $\begin{array}{l}21.71(0.85) \\
0-84\end{array}$ & $\begin{array}{c}15.53(0.42) \\
0-82\end{array}$ & $\begin{array}{l}25.13(0.53) \\
1-75\end{array}$ \\
\hline American Coot & 595 & 0.500 & $\begin{array}{c}7(0.69) \\
0.01-204.26\end{array}$ & $\begin{array}{l}47.36(1.18) \\
0-100\end{array}$ & $\begin{array}{c}24.27(0.97) \\
0-95\end{array}$ & $\begin{array}{l}26.01(1.1) \\
0-100\end{array}$ & $\begin{array}{c}2.38(0.24) \\
0-90\end{array}$ & $\begin{array}{c}56.96(0.91) \\
0-97\end{array}$ & $\begin{array}{l}23.2(0.87) \\
0-89\end{array}$ & $\begin{array}{c}14.6(0.37) \\
0-82\end{array}$ & $\begin{array}{c}26.61(0.52) \\
1-75\end{array}$ \\
\hline Gadwall & 565 & 0.475 & $\begin{array}{r}7.33(0.72) \\
0.01-204.26\end{array}$ & $\begin{array}{l}47.38(1.28) \\
0-100\end{array}$ & $\begin{array}{c}22.26(1.01) \\
0-100\end{array}$ & $\begin{array}{c}27.09(1.21) \\
0-100\end{array}$ & $\begin{array}{l}3.12(0.26) \\
0-40\end{array}$ & $\begin{array}{l}58.46(0.92) \\
3-97\end{array}$ & $\begin{array}{l}21.32(0.85) \\
0-87\end{array}$ & $\begin{array}{c}14.66(0.41) \\
0-82\end{array}$ & $\begin{array}{c}24.38(0.52) \\
1-75\end{array}$ \\
\hline $\begin{array}{l}\text { Common } \\
\text { Yellowthroat }\end{array}$ & 523 & 0.439 & $\begin{array}{c}5.27(0.57) \\
0.01-130\end{array}$ & $\begin{array}{l}37.86(1.3) \\
0-100\end{array}$ & $\begin{array}{c}30.89(1.22) \\
0-100\end{array}$ & $\begin{array}{c}29.05(1.29) \\
0-100\end{array}$ & $\begin{array}{l}2(0.24) \\
0-50\end{array}$ & $\begin{array}{l}56.93(0.95) \\
5-97\end{array}$ & $\begin{array}{l}22.14(0.9) \\
0-84\end{array}$ & $\begin{array}{c}15.18(0.45) \\
0-82\end{array}$ & $\begin{array}{c}25.74(0.54) \\
1-66\end{array}$ \\
\hline $\begin{array}{l}\text { Yellow-headed } \\
\text { Blackbird }\end{array}$ & 470 & 0.395 & $\begin{array}{c}7.28(0.68) \\
0.02-130\end{array}$ & $\begin{array}{l}44.21(1.32) \\
0-100\end{array}$ & $\begin{array}{l}32.49(1.16) \\
0-95\end{array}$ & $\begin{array}{l}21.21(1.05) \\
0-100\end{array}$ & $\begin{array}{l}2.1(0.27) \\
0-90\end{array}$ & $\begin{array}{l}54.5(1.02) \\
2-97\end{array}$ & $\begin{array}{l}24.11(0.99) \\
0-89\end{array}$ & $\begin{array}{c}15.73(0.43) \\
0-82\end{array}$ & $\begin{array}{c}26(0.58) \\
1-75\end{array}$ \\
\hline Northern Shoveler & 331 & 0.278 & $\begin{array}{r}7.64(0.98) \\
0.02-204.26\end{array}$ & $\begin{array}{l}46.79(1.59) \\
0-100\end{array}$ & $\begin{array}{c}21.68(1.27) \\
0-100\end{array}$ & $\begin{array}{c}28.17(1.55) \\
0-100\end{array}$ & $\begin{array}{c}3.34(0.35) \\
0-35\end{array}$ & $\begin{array}{l}56.91(1.21) \\
2-97\end{array}$ & $\begin{array}{c}22.65(1.11) \\
0-89\end{array}$ & $\begin{array}{c}15.27(0.6) \\
0-82\end{array}$ & $\begin{array}{c}25.24(0.77) \\
1-75\end{array}$ \\
\hline Savannah Sparrow & 311 & 0.261 & $\begin{array}{r}8.06(1.17) \\
0.01-204.26\end{array}$ & $\begin{array}{c}42.96(1.79) \\
0-99\end{array}$ & $\begin{array}{c}21.34(1.39) \\
0-100\end{array}$ & $\begin{array}{c}32.25(1.85) \\
0-100\end{array}$ & $\begin{array}{c}3.16(0.34) \\
0-50\end{array}$ & $\begin{array}{c}60.93(1.17) \\
3-96\end{array}$ & $\begin{array}{l}20.11(1.14) \\
0-85\end{array}$ & $\begin{array}{c}13.95(0.58) \\
0-82\end{array}$ & $\begin{array}{c}27.14(0.78) \\
1-75\end{array}$ \\
\hline
\end{tabular}




\begin{tabular}{|c|c|c|c|c|c|c|c|c|c|c|c|}
\hline \multirow[b]{2}{*}{ Common name } & \multirow{2}{*}{$\begin{array}{l}\text { Number } \\
\text { of } \\
\text { wetlands } \\
\text { with } \\
\text { species } \\
\text { present }\end{array}$} & \multirow{2}{*}{$\begin{array}{l}\text { Proportion } \\
\text { of } \\
\text { wetlands } \\
\text { with } \\
\text { species } \\
\text { present }\end{array}$} & \multicolumn{5}{|c|}{ Wetland-level variables } & \multicolumn{4}{|c|}{ Landscape-level variables } \\
\hline & & & $\begin{array}{c}\text { Wetland size } \\
\text { (hectares) }\end{array}$ & $\begin{array}{l}\text { Percentage of } \\
\text { wetland in } \\
\text { open water }\end{array}$ & $\begin{array}{l}\text { Percentage of } \\
\text { the wetland in } \\
\text { emergent } \\
\text { vegetation }\end{array}$ & $\begin{array}{l}\text { Percentage of } \\
\text { the wetland in } \\
\text { wet meadow }\end{array}$ & $\begin{array}{l}\text { Percentage } \\
\text { of the } \\
\text { wetland in } \\
\text { shorelinel } \\
\text { mudflat }\end{array}$ & $\begin{array}{l}\text { Percentage of } \\
\text { grassland } \\
\text { area within } \\
800 \mathrm{~m}\end{array}$ & $\begin{array}{l}\text { Percentage of } \\
\text { agricultural } \\
\text { area within } \\
800 \mathrm{~m}\end{array}$ & $\begin{array}{c}\text { Percentage } \\
\text { of wetland } \\
\text { area within } \\
800 \mathrm{~m}\end{array}$ & $\begin{array}{c}\text { Number of } \\
\text { wetlands } \\
\text { within } 800 \mathrm{~m}\end{array}$ \\
\hline Black Tern & 285 & 0.239 & $\begin{array}{c}10.17(1.09) \\
0.02-130\end{array}$ & $\begin{array}{c}50.29(1.66) \\
0-100\end{array}$ & $\begin{array}{l}26.7(1.39) \\
0-92\end{array}$ & $\begin{array}{c}19.86(1.29) \\
0-100\end{array}$ & $\begin{array}{l}3.14(0.44) \\
0-90\end{array}$ & $\begin{array}{c}56.47(1.35) \\
0-92\end{array}$ & $\begin{array}{c}22.39(1.31) \\
0-89\end{array}$ & $\begin{array}{c}15.84(0.56) \\
2-82\end{array}$ & $\begin{array}{c}27.35(0.81) \\
1-75\end{array}$ \\
\hline Sora & 283 & 0.238 & $\begin{array}{c}6.24(0.79) \\
0.02-70\end{array}$ & $\begin{array}{l}32.36(1.57) \\
0-95\end{array}$ & $\begin{array}{c}35.08(1.69) \\
0-100\end{array}$ & $\begin{array}{c}30.82(1.73) \\
0-100\end{array}$ & $\begin{array}{l}1.74(0.25) \\
0-40\end{array}$ & $\begin{array}{l}54.76(1.36) \\
1-94\end{array}$ & $\begin{array}{l}25.23(1.35) \\
0-88\end{array}$ & $\begin{array}{l}14.4(0.65) \\
0-82\end{array}$ & $\begin{array}{c}26.49(0.81) \\
1-75\end{array}$ \\
\hline Pied-billed Grebe & 280 & 0.235 & $\begin{array}{r}11.61(1.14) \\
0.05-130\end{array}$ & $\begin{array}{c}50.99(1.58) \\
0-100\end{array}$ & $\begin{array}{l}25.16(1.26) \\
\quad 0-92\end{array}$ & $\begin{array}{c}22.1(1.3) \\
0-100\end{array}$ & $\begin{array}{c}1.75(0.24) \\
0-30\end{array}$ & $\begin{array}{l}57.49(1.3) \\
6-97\end{array}$ & $\begin{array}{l}21.14(1.23) \\
0-87\end{array}$ & $\begin{array}{c}16.13(0.59) \\
0-82\end{array}$ & $\begin{array}{c}24.25(0.77) \\
1-75\end{array}$ \\
\hline Killdeer & 262 & 0.220 & $\begin{array}{r}8.89(1.23) \\
0.02-204.26\end{array}$ & $\begin{array}{l}45.11(1.9) \\
0-100\end{array}$ & $\begin{array}{c}23.75(1.55) \\
0-100\end{array}$ & $\begin{array}{c}26.06(1.73) \\
0-100\end{array}$ & $\begin{array}{l}5.08(0.52) \\
0-60\end{array}$ & $\begin{array}{l}53.79(1.42) \\
2-93\end{array}$ & $\begin{array}{l}25.68(1.42) \\
0-89\end{array}$ & $\begin{array}{c}14.69(0.62) \\
0-82\end{array}$ & $\begin{array}{c}25.27(0.82) \\
1-64\end{array}$ \\
\hline Common Grackle & 258 & 0.217 & $\begin{array}{c}9.21(1.02) \\
0.04-100\end{array}$ & $\begin{array}{l}53.65(1.84) \\
0-100\end{array}$ & $\begin{array}{l}23.33(1.5) \\
0-100\end{array}$ & $\begin{array}{l}20.13(1.5) \\
0-100\end{array}$ & $\begin{array}{l}2.9(0.39) \\
0-50\end{array}$ & $\begin{array}{l}54.79(1.31) \\
1-92\end{array}$ & $\begin{array}{l}23.21(1.26) \\
\quad 0-85\end{array}$ & $\begin{array}{c}15.88(0.59) \\
0-63\end{array}$ & $\begin{array}{l}25.88(0.8) \\
1-64\end{array}$ \\
\hline Eastern Kingbird & 256 & 0.215 & $\begin{array}{l}11.48(1.42) \\
0.08-204.26\end{array}$ & $\begin{array}{c}48.71(1.87) \\
0-100\end{array}$ & $\begin{array}{l}24.65(1.52) \\
\quad 0-95\end{array}$ & $\begin{array}{c}23.55(1.63) \\
0-100\end{array}$ & $\begin{array}{l}3.09(0.41) \\
0-50\end{array}$ & $\begin{array}{l}58.04(1.33) \\
7-97\end{array}$ & $\begin{array}{l}20.48(1.19) \\
0-81\end{array}$ & $\begin{array}{c}15.86(0.72) \\
0-82\end{array}$ & $\begin{array}{c}23.14(0.75) \\
1-61\end{array}$ \\
\hline Ruddy Duck & 255 & 0.214 & $\begin{array}{r}13.73(1.45) \\
0.1-204.26\end{array}$ & $\begin{array}{c}54.31(1.68) \\
0-100\end{array}$ & $\begin{array}{l}24.38(1.31) \\
\quad 0-85\end{array}$ & $\begin{array}{l}18.78(1.27) \\
0-95\end{array}$ & $\begin{array}{l}2.53(0.43) \\
0-90\end{array}$ & $\begin{array}{c}55.89(1.42) \\
1-97\end{array}$ & $\begin{array}{l}21.82(1.29) \\
0-79\end{array}$ & $\begin{array}{c}16.89(0.68) \\
0-82\end{array}$ & $\begin{array}{c}22.97(0.73) \\
1-60\end{array}$ \\
\hline Marsh Wren & 242 & 0.203 & $\begin{array}{l}7.3(0.97) \\
0.03-130\end{array}$ & $\begin{array}{c}36.22(1.73) \\
0-94\end{array}$ & $\begin{array}{c}42.23(1.66) \\
0-100\end{array}$ & $\begin{array}{c}20.23(1.35) \\
0-100\end{array}$ & $\begin{array}{l}1.32(0.22) \\
0-30\end{array}$ & $\begin{array}{l}52.92(1.46) \\
\quad 7-96\end{array}$ & $\begin{array}{l}23.71(1.4) \\
0-84\end{array}$ & $\begin{array}{c}18(0.82) \\
0-82\end{array}$ & $\begin{array}{c}27.03(0.91) \\
1-75\end{array}$ \\
\hline Song Sparrow & 237 & 0.199 & $\begin{array}{c}8.87(1.22) \\
0.03-130\end{array}$ & $\begin{array}{c}47.29(2.04) \\
0-100\end{array}$ & $\begin{array}{c}25.73(1.68) \\
0-100\end{array}$ & $\begin{array}{l}23.76(1.7) \\
0-100\end{array}$ & $\begin{array}{l}2.8(0.43) \\
0-50\end{array}$ & $\begin{array}{l}53.29(1.39) \\
\quad 6-88\end{array}$ & $\begin{array}{l}24.54(1.38) \\
0-84\end{array}$ & $\begin{array}{c}16.07(0.65) \\
0-63\end{array}$ & $\begin{array}{c}24.57(0.77) \\
1-64\end{array}$ \\
\hline Redhead & 231 & 0.194 & $\begin{array}{l}12.34(1.54) \\
0.05-204.26\end{array}$ & $\begin{array}{c}52.55(1.84) \\
0-100\end{array}$ & $\begin{array}{l}27.19(1.62) \\
\quad 0-92\end{array}$ & $\begin{array}{l}17.21(1.21) \\
0-98\end{array}$ & $\begin{array}{l}3.05(0.5) \\
0-90\end{array}$ & $\begin{array}{l}53.77(1.51) \\
\quad 7-97\end{array}$ & $\begin{array}{l}23.67(1.38) \\
0-79\end{array}$ & $\begin{array}{c}17.13(0.79) \\
0-82\end{array}$ & $\begin{array}{c}25.15(0.93) \\
1-75\end{array}$ \\
\hline Bobolink & 216 & 0.182 & $\begin{array}{c}6.78(1.05) \\
0.01-100\end{array}$ & $\begin{array}{l}40.79(1.96) \\
0-95\end{array}$ & $\begin{array}{c}25.97(1.76) \\
0-100\end{array}$ & $\begin{array}{c}30.78(2.09) \\
0-100\end{array}$ & $\begin{array}{l}2.46(0.31) \\
0-30\end{array}$ & $\begin{array}{l}59.42(1.58) \\
0-97\end{array}$ & $\begin{array}{l}20.69(1.53) \\
0-84\end{array}$ & $\begin{array}{c}14.49(0.76) \\
0-82\end{array}$ & $\begin{array}{c}26.66(0.86) \\
1-64\end{array}$ \\
\hline $\begin{array}{l}\text { Brown-headed } \\
\text { Cowbird }\end{array}$ & 211 & 0.177 & $\begin{array}{r}10.53(1.35) \\
0.03-130\end{array}$ & $\begin{array}{c}46.55(2.13) \\
0-100\end{array}$ & $\begin{array}{c}25.93(1.84) \\
0-97\end{array}$ & $\begin{array}{c}24.09(1.82) \\
0-100\end{array}$ & $\begin{array}{c}3.43(0.45) \\
0-35\end{array}$ & $\begin{array}{l}55.75(1.48) \\
9-92\end{array}$ & $\begin{array}{l}22.66(1.38) \\
0-85\end{array}$ & $\begin{array}{l}16.3(0.81) \\
1-77\end{array}$ & $\begin{array}{c}24.08(0.88) \\
1-75\end{array}$ \\
\hline
\end{tabular}




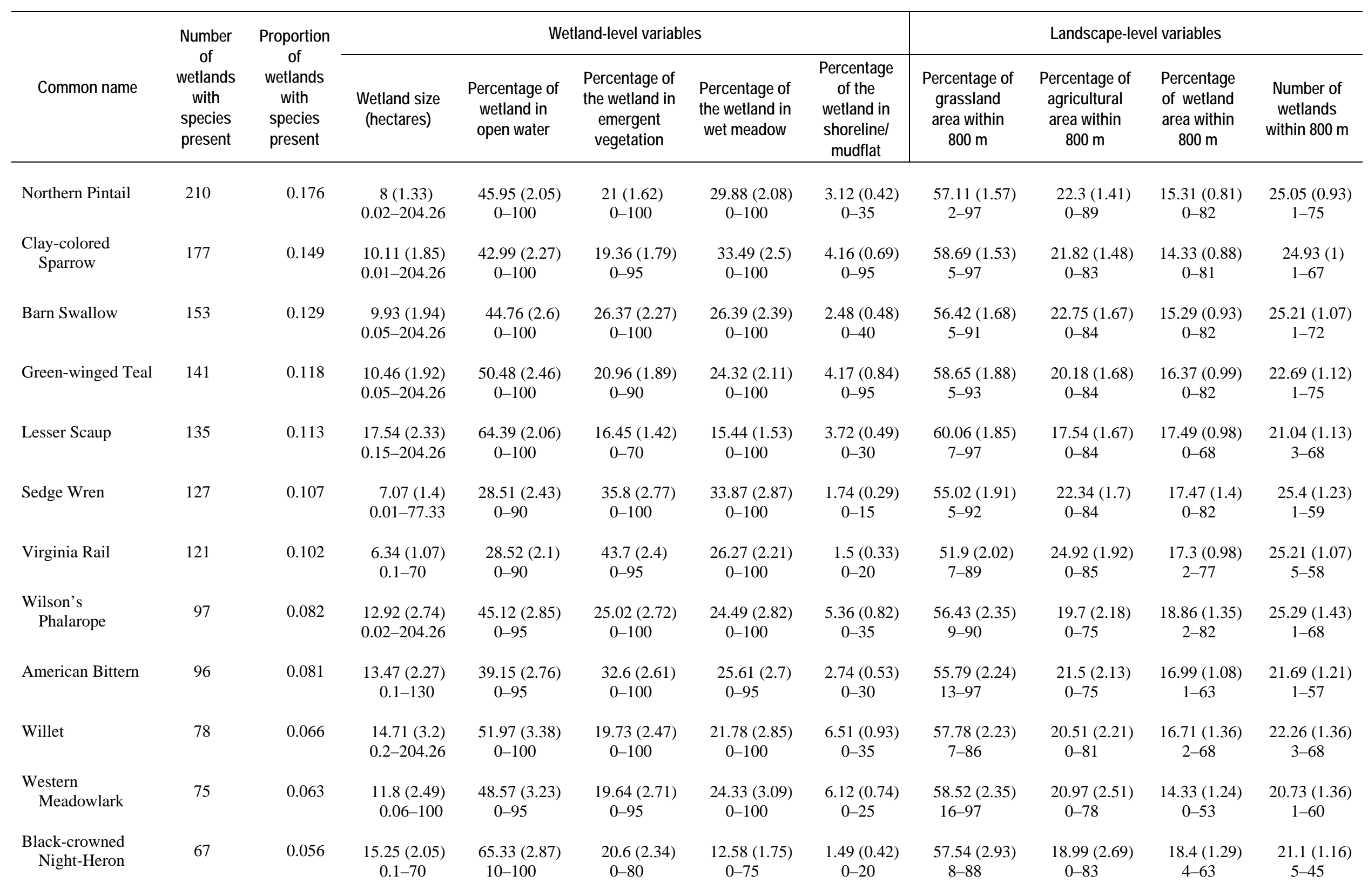




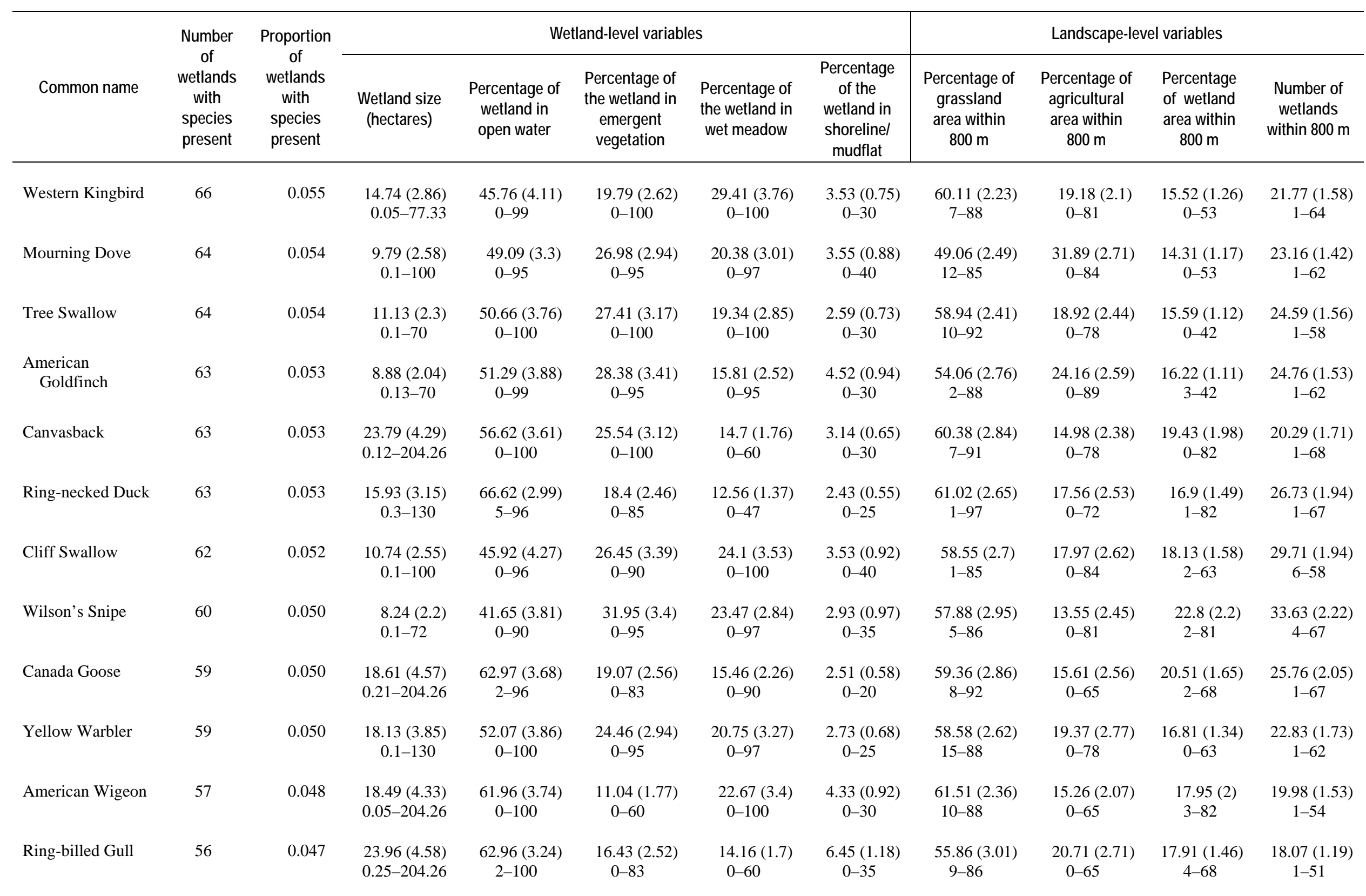




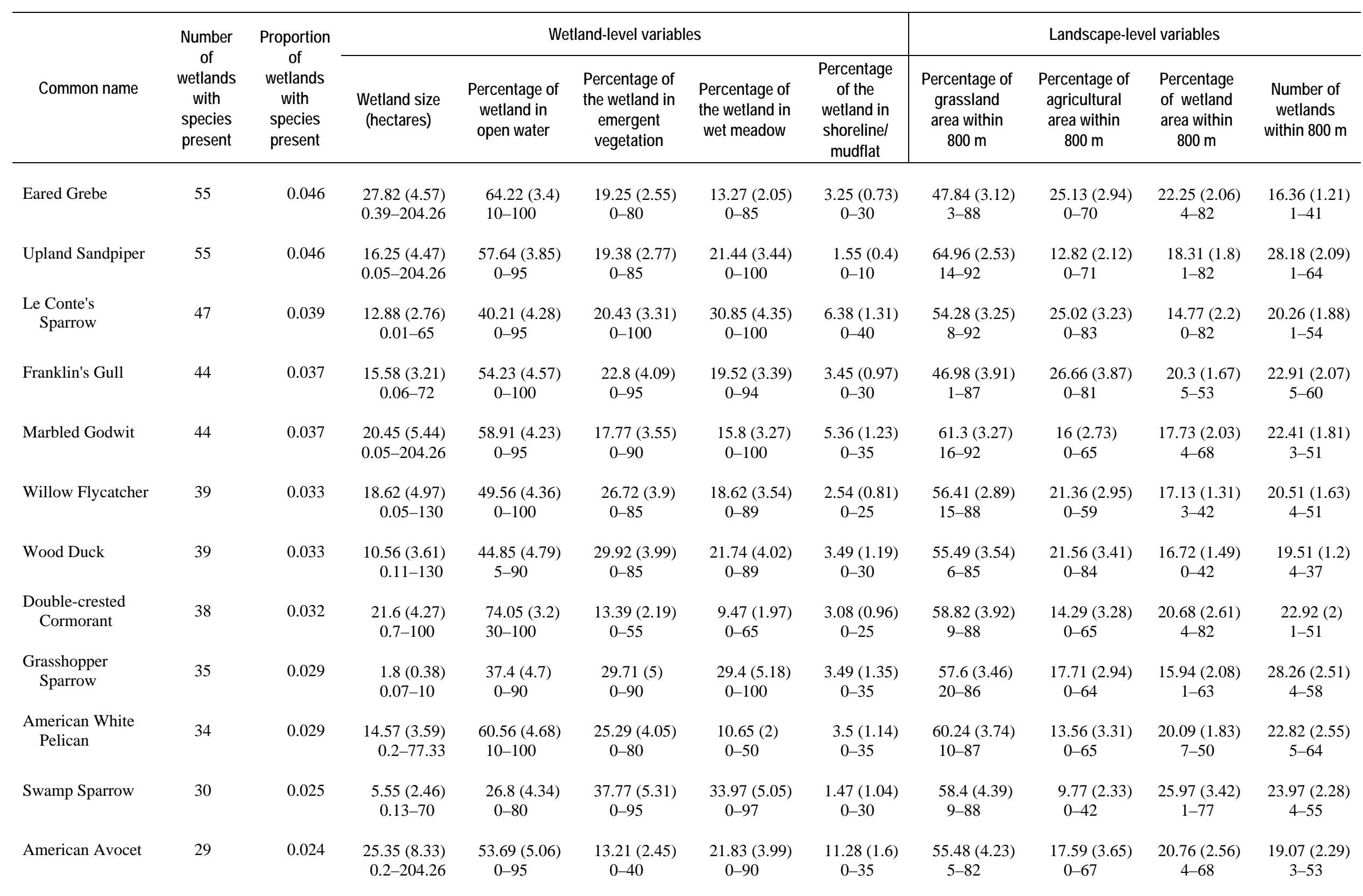




\begin{tabular}{|c|c|c|c|c|c|c|c|c|c|c|c|}
\hline \multirow[b]{2}{*}{ Common name } & \multirow{2}{*}{$\begin{array}{l}\text { Number } \\
\text { of } \\
\text { wetlands } \\
\text { with } \\
\text { species } \\
\text { present }\end{array}$} & \multirow{2}{*}{$\begin{array}{l}\text { Proportion } \\
\text { of } \\
\text { wetlands } \\
\text { with } \\
\text { species } \\
\text { present }\end{array}$} & \multicolumn{5}{|c|}{ Wetland-level variables } & \multicolumn{4}{|c|}{ Landscape-level variables } \\
\hline & & & $\begin{array}{l}\text { Wetland size } \\
\text { (hectares) }\end{array}$ & $\begin{array}{l}\text { Percentage of } \\
\text { wetland in } \\
\text { open water }\end{array}$ & $\begin{array}{l}\text { Percentage of } \\
\text { the wetland in } \\
\text { emergent } \\
\text { vegetation }\end{array}$ & $\begin{array}{l}\text { Percentage of } \\
\text { the wetland in } \\
\text { wet meadow }\end{array}$ & $\begin{array}{l}\text { Percentage } \\
\text { of the } \\
\text { wetland in } \\
\text { shorelinel } \\
\text { mudflat }\end{array}$ & $\begin{array}{l}\text { Percentage of } \\
\text { grassland } \\
\text { area within } \\
800 \mathrm{~m}\end{array}$ & $\begin{array}{l}\text { Percentage of } \\
\text { agricultural } \\
\text { area within } \\
800 \mathrm{~m}\end{array}$ & $\begin{array}{l}\text { Percentage } \\
\text { of wetland } \\
\text { area within } \\
\quad 800 \mathrm{~m}\end{array}$ & $\begin{array}{c}\text { Number of } \\
\text { wetlands } \\
\text { within } 800 \mathrm{~m}\end{array}$ \\
\hline Horned Grebe & 28 & 0.024 & $\begin{array}{r}21.86(4.63) \\
0.2-77.33\end{array}$ & $\begin{array}{l}61.32(3.55) \\
20-95\end{array}$ & $\begin{array}{c}17.25(3.29) \\
0-65\end{array}$ & $\begin{array}{c}16.11(2.11) \\
0-35\end{array}$ & $\begin{array}{c}5.32(1.01) \\
0-20\end{array}$ & $\begin{array}{l}60.14(3.45) \\
23-88\end{array}$ & $\begin{array}{c}18.29(3.24) \\
0-62\end{array}$ & $\begin{array}{c}17.04(2.15) \\
3-50\end{array}$ & $\begin{array}{c}17.54(1.77) \\
1-40\end{array}$ \\
\hline Horned Lark & 26 & 0.022 & $\begin{array}{l}21.11(8.75) \\
0.06-204.26\end{array}$ & $\begin{array}{l}43.46(6) \\
0-90\end{array}$ & $\begin{array}{l}21.92(5.26) \\
\quad 0-85\end{array}$ & $\begin{array}{l}17.38(3.67) \\
0-85\end{array}$ & $\begin{array}{c}13.58(5.1) \\
0-100\end{array}$ & $\begin{array}{l}37.81(4.16) \\
1-80\end{array}$ & $\begin{array}{l}41.62(5.2) \\
0-88\end{array}$ & $\begin{array}{c}15.65(2.67) \\
2-68\end{array}$ & $\begin{array}{c}20.42(2.44) \\
1-47\end{array}$ \\
\hline $\begin{array}{l}\text { Ring-necked } \\
\text { Pheasant }\end{array}$ & 22 & 0.018 & $\begin{array}{c}3.41(1.23) \\
0.08-25\end{array}$ & $\begin{array}{l}29.91(6.32) \\
0-95\end{array}$ & $\begin{array}{c}28.18(6.72) \\
0-100\end{array}$ & $\begin{array}{c}40.09(7.65) \\
0-90\end{array}$ & $\begin{array}{c}1.82(0.84) \\
0-15\end{array}$ & $\begin{array}{l}50.32(3.82) \\
\quad 6-79\end{array}$ & $\begin{array}{l}28.77(3.85) \\
\quad 4-84\end{array}$ & $\begin{array}{c}15.27(1.68) \\
0-31\end{array}$ & $\begin{array}{l}23.27(1.6) \\
6-34\end{array}$ \\
\hline American Robin & 21 & 0.018 & $\begin{array}{l}3.69(1.11) \\
0.05-17.41\end{array}$ & $\begin{array}{l}52.76(7.86) \\
0-96\end{array}$ & $\begin{array}{l}23.29(6.36) \\
0-95\end{array}$ & $\begin{array}{l}14.71(4.45) \\
0-75\end{array}$ & $\begin{array}{l}4.48(2.03) \\
0-40\end{array}$ & $\begin{array}{l}53.05(4.17) \\
25-85\end{array}$ & $\begin{array}{l}27.19(4.74) \\
\quad 0-69\end{array}$ & $\begin{array}{l}13.76(1.4) \\
1-28\end{array}$ & $\begin{array}{c}25.67(2.17) \\
\quad 8-51\end{array}$ \\
\hline House Wren & 20 & 0.017 & $\begin{array}{l}4.79(2.2) \\
0.05-32\end{array}$ & $\begin{array}{l}35.4(6.92) \\
0-93\end{array}$ & $\begin{array}{l}22.15(5.18) \\
\quad 0-80\end{array}$ & $\begin{array}{c}34.35(7.53) \\
0-100\end{array}$ & $\begin{array}{l}3.1(1.42) \\
0-20\end{array}$ & $\begin{array}{l}57.3(4.67) \\
17-97\end{array}$ & $\begin{array}{l}23.2(3.86) \\
0-54\end{array}$ & $\begin{array}{c}13.6(1.83) \\
0-30\end{array}$ & $\begin{array}{l}28.4(2.78) \\
9-62\end{array}$ \\
\hline Nelson's Sparrow & 20 & 0.017 & $\begin{array}{c}11.35(3.33) \\
0.2-42\end{array}$ & $\begin{array}{l}42.25(6.24) \\
0-85\end{array}$ & $\begin{array}{l}15(3.79) \\
0-50\end{array}$ & $\begin{array}{c}34(6.52) \\
0-100\end{array}$ & $\begin{array}{c}8.75(5.06) \\
0-100\end{array}$ & $\begin{array}{l}49.4(5.69) \\
9-88\end{array}$ & $\begin{array}{l}30.4(5.19) \\
0-78\end{array}$ & $\begin{array}{l}15.8(2.19) \\
0-32\end{array}$ & $\begin{array}{l}21.7(2.69) \\
3-42\end{array}$ \\
\hline Northern Harrier & 20 & 0.017 & $\begin{array}{r}23.56(10.38) \\
0.01-204.26\end{array}$ & $\begin{array}{l}47.25(6.94) \\
\quad 0-90\end{array}$ & $\begin{array}{l}27.8(6.21) \\
0-95\end{array}$ & $\begin{array}{l}22.4(7.46) \\
0-100\end{array}$ & $\begin{array}{l}2.55(0.93) \\
0-10\end{array}$ & $\begin{array}{l}54.55(4.83) \\
17-88\end{array}$ & $\begin{array}{l}20.25(5.39) \\
0-76\end{array}$ & $\begin{array}{l}19.45(3.9) \\
2-68\end{array}$ & $\begin{array}{l}21.4(2.72) \\
3-47\end{array}$ \\
\hline Baltimore Oriole & 18 & 0.015 & $\begin{array}{c}15.92(5.09) \\
0.2-64\end{array}$ & $\begin{array}{l}54.61(7.71) \\
0-90\end{array}$ & $\begin{array}{l}17.44(3.45) \\
\quad 5-40\end{array}$ & $\begin{array}{l}26.44(5.59) \\
\quad 3-80\end{array}$ & $\begin{array}{l}1.5(0.78) \\
0-10\end{array}$ & $\begin{array}{l}60.06(4.03) \\
25-85\end{array}$ & $\begin{array}{l}17.22(3.17) \\
\quad 0-40\end{array}$ & $\begin{array}{c}17.39(3.86) \\
3-63\end{array}$ & $\begin{array}{l}20.33(2.23) \\
1-40\end{array}$ \\
\hline $\begin{array}{l}\text { Chestnut-collared } \\
\text { Longspur }\end{array}$ & 18 & 0.015 & $\begin{array}{c}15.37(6.3) \\
0.03-100\end{array}$ & $\begin{array}{l}53.33(6.39) \\
0-90\end{array}$ & $\begin{array}{l}8.5(3.31) \\
0-45\end{array}$ & $\begin{array}{l}26.5(7.38) \\
0-100\end{array}$ & $\begin{array}{c}11.67(2.52) \\
0-30\end{array}$ & $\begin{array}{l}64.11(4.7) \\
9-80\end{array}$ & $\begin{array}{l}11(3.67) \\
0-55\end{array}$ & $\begin{array}{c}17.78(2.96) \\
0-42\end{array}$ & $\begin{array}{l}22(3.59) \\
5-54\end{array}$ \\
\hline Gray Catbird & 17 & 0.014 & $\begin{array}{c}28.42(9.58) \\
0.2-130\end{array}$ & $\begin{array}{c}51(6.11) \\
0-89\end{array}$ & $\begin{array}{l}26.18(4.57) \\
\quad 5-75\end{array}$ & $\begin{array}{l}19.18(5.73) \\
0-90\end{array}$ & $\begin{array}{l}3.65(1.64) \\
0-25\end{array}$ & $\begin{array}{l}60(3.38) \\
41-82\end{array}$ & $\begin{array}{l}19.41(3.57) \\
0-41\end{array}$ & $\begin{array}{c}15.59(1.93) \\
2-33\end{array}$ & $\begin{array}{c}19.59(1.86) \\
4-31\end{array}$ \\
\hline Orchard Oriole & 16 & 0.013 & $\begin{array}{c}10.82(5.31) \\
0.05-65\end{array}$ & $\begin{array}{l}39.25(7.5) \\
0-85\end{array}$ & $\begin{array}{l}25.88(6.12) \\
0-85\end{array}$ & $\begin{array}{l}25.5(6.54) \\
0-80\end{array}$ & $\begin{array}{c}3.13(2.23) \\
0-35\end{array}$ & $\begin{array}{l}60.56(4.36) \\
23-83\end{array}$ & $\begin{array}{l}16.81(4.2) \\
0-60\end{array}$ & $\begin{array}{c}16.88(3) \\
4-53\end{array}$ & $\begin{array}{c}24.63(2.71) \\
10-51\end{array}$ \\
\hline
\end{tabular}




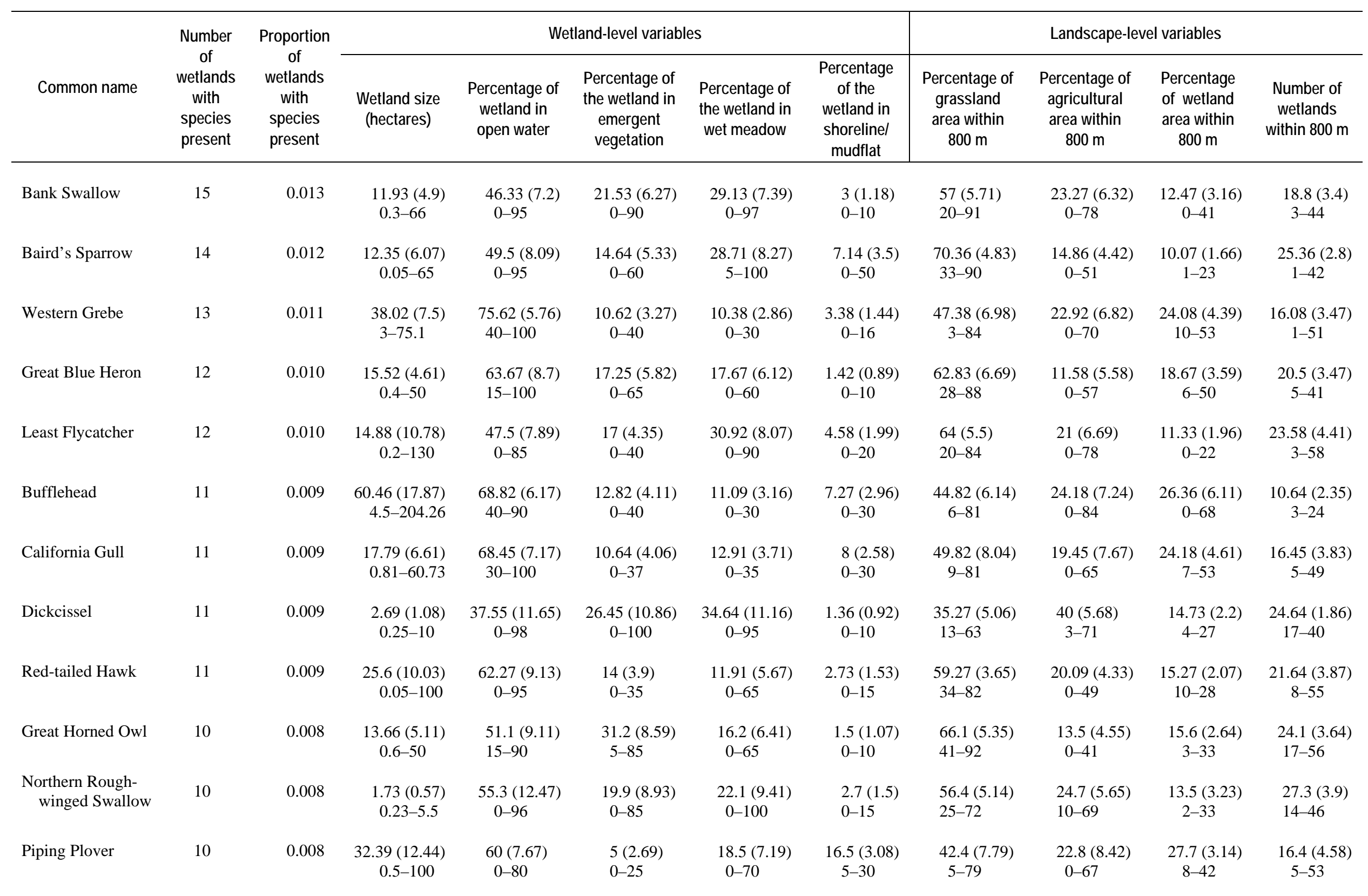




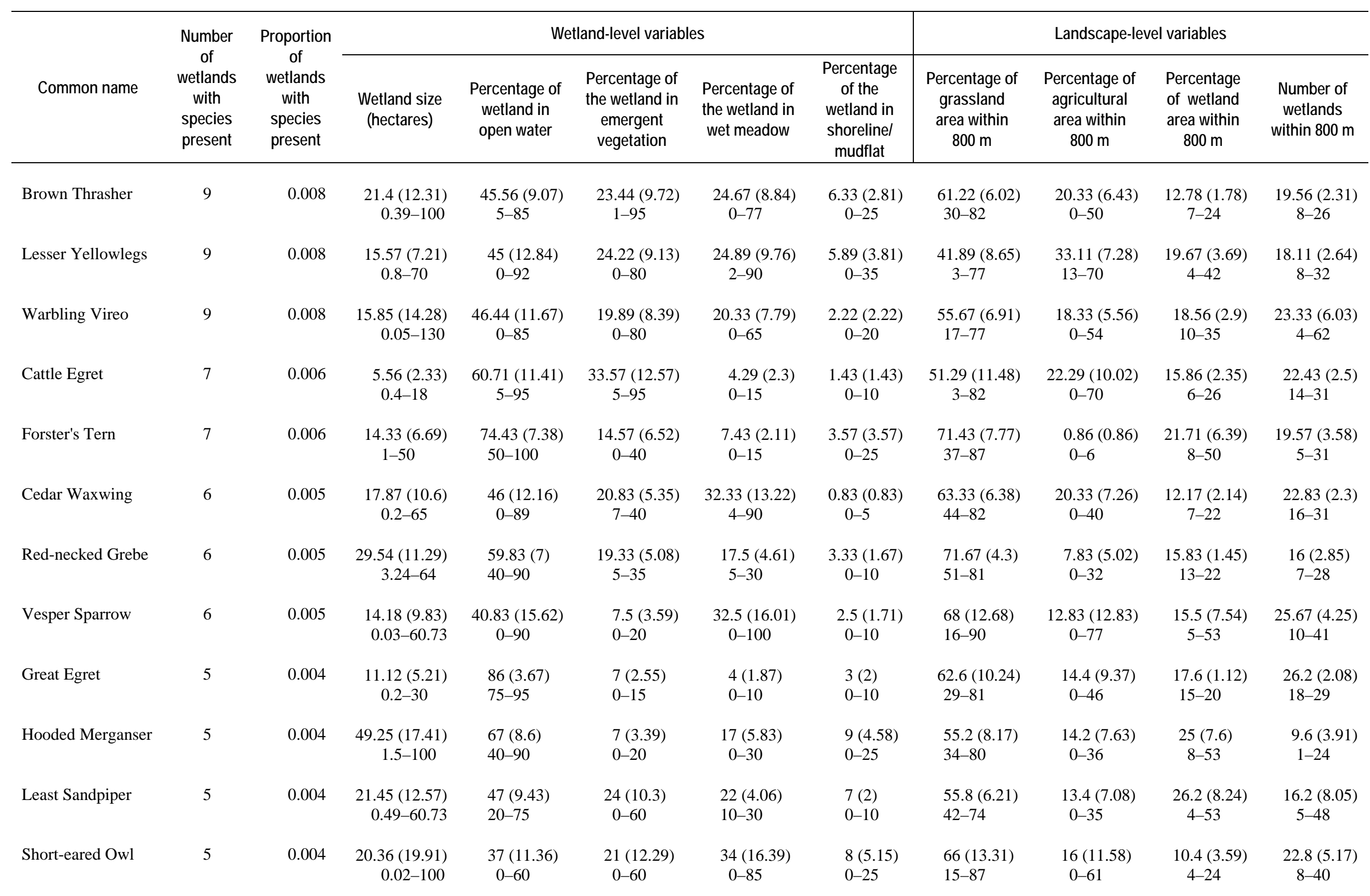




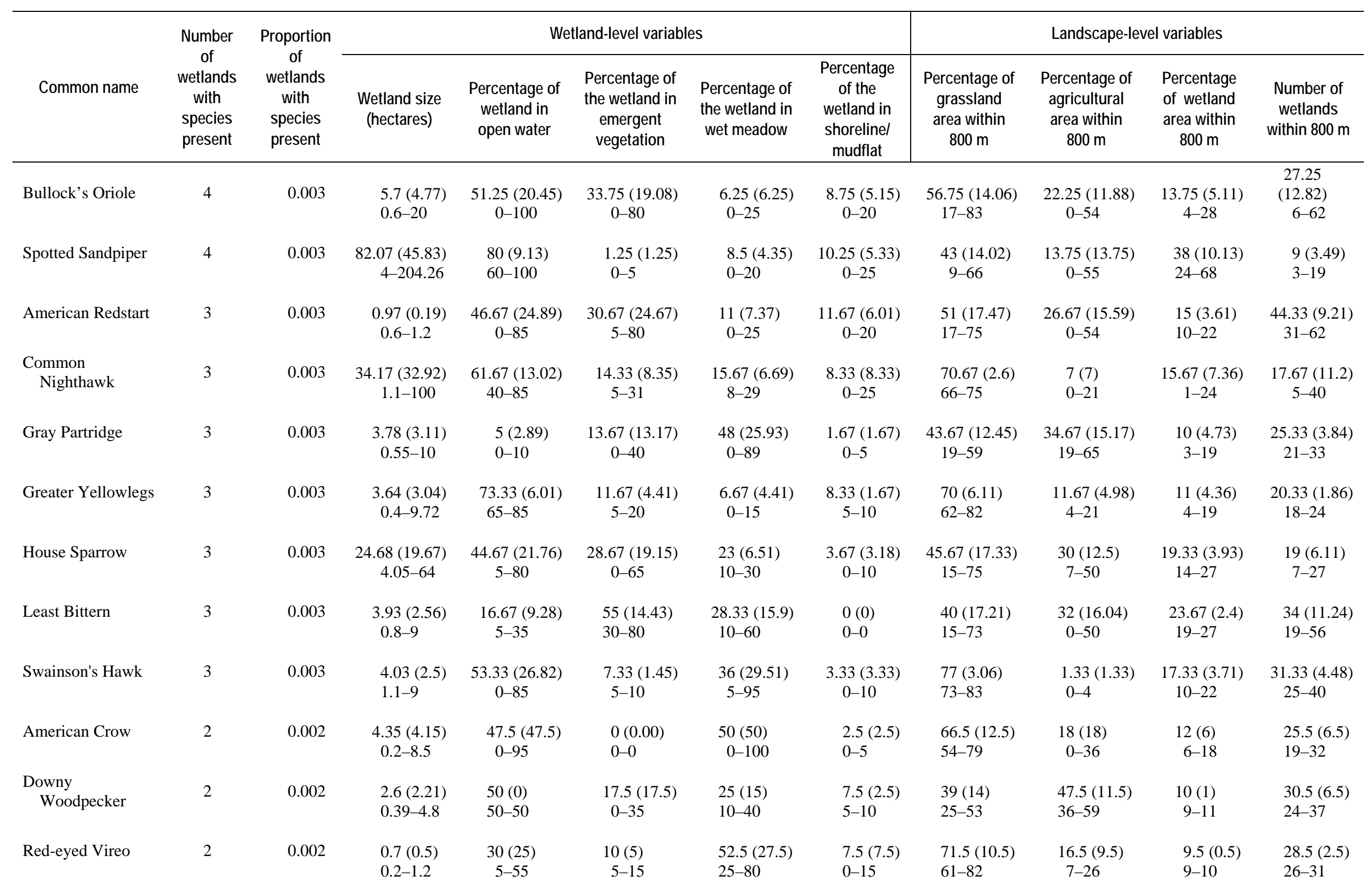




\begin{tabular}{|c|c|c|c|c|c|c|c|c|c|c|c|}
\hline \multirow[b]{2}{*}{ Common name } & \multirow{2}{*}{$\begin{array}{l}\text { Number } \\
\text { of } \\
\text { wetlands } \\
\text { with } \\
\text { species } \\
\text { present }\end{array}$} & \multirow{2}{*}{$\begin{array}{l}\text { Proportion } \\
\text { of } \\
\text { wetlands } \\
\text { with } \\
\text { species } \\
\text { present }\end{array}$} & \multicolumn{5}{|c|}{ Wetland-level variables } & \multicolumn{4}{|c|}{ Landscape-level variables } \\
\hline & & & $\begin{array}{l}\text { Wetland size } \\
\text { (hectares) }\end{array}$ & $\begin{array}{l}\text { Percentage of } \\
\text { wetland in } \\
\text { open water }\end{array}$ & $\begin{array}{l}\text { Percentage of } \\
\text { the wetland in } \\
\text { emergent } \\
\text { vegetation }\end{array}$ & $\begin{array}{l}\text { Percentage of } \\
\text { the wetland in } \\
\text { wet meadow }\end{array}$ & $\begin{array}{l}\text { Percentage } \\
\text { of the } \\
\text { wetland in } \\
\text { shorelinel } \\
\text { mudflat }\end{array}$ & $\begin{array}{l}\text { Percentage of } \\
\text { grassland } \\
\text { area within } \\
800 \mathrm{~m}\end{array}$ & $\begin{array}{l}\text { Percentage of } \\
\text { agricultural } \\
\text { area within } \\
800 \mathrm{~m}\end{array}$ & $\begin{array}{c}\text { Percentage } \\
\text { of wetland } \\
\text { area within } \\
800 \mathrm{~m}\end{array}$ & $\begin{array}{c}\text { Number of } \\
\text { wetlands } \\
\text { within } 800 \mathrm{~m}\end{array}$ \\
\hline White-faced Ibis & 2 & 0.002 & $\begin{array}{l}7.5(0.5) \\
7-8\end{array}$ & $\begin{array}{l}22.5(17.5) \\
5-40\end{array}$ & $\begin{array}{l}37.5(2.5) \\
35-40\end{array}$ & $\begin{array}{l}40(20) \\
20-60\end{array}$ & $\begin{array}{l}0(0) \\
0-0\end{array}$ & $\begin{array}{l}48(2) \\
46-50\end{array}$ & $\begin{array}{l}10.5(3.5) \\
7-14\end{array}$ & $\begin{array}{l}35.5(0.5) \\
35-36\end{array}$ & $\begin{array}{l}24.5(3.5) \\
21-28\end{array}$ \\
\hline $\begin{array}{l}\text { White-rumped } \\
\text { Sandpiper }\end{array}$ & 2 & 0.002 & $\begin{array}{l}12.7(12.3) \\
0.4-25\end{array}$ & $\begin{array}{l}52.5(2.5) \\
50-55\end{array}$ & $\begin{array}{l}22.5(7.5) \\
15-30\end{array}$ & $\begin{array}{c}15(15) \\
0-30\end{array}$ & $\begin{array}{c}10(10) \\
0-20\end{array}$ & $\begin{array}{l}38.5(36.5) \\
2-75\end{array}$ & $\begin{array}{l}44.5(44.5) \\
0-89\end{array}$ & $\begin{array}{l}14.5(7.5) \\
7-22\end{array}$ & $\begin{array}{l}26(11) \\
15-37\end{array}$ \\
\hline $\begin{array}{l}\text { Yellow-rumped } \\
\text { Warbler }\end{array}$ & 2 & 0.002 & $\begin{array}{r}37.62(23.12) \\
14.5-60.73\end{array}$ & $\begin{array}{l}62.5(22.5) \\
40-85\end{array}$ & $\begin{array}{l}15(5) \\
10-20\end{array}$ & $\begin{array}{l}16.5(13.5) \\
3-30\end{array}$ & $\begin{array}{l}6(4) \\
2-10\end{array}$ & $\begin{array}{l}51.5(8.5) \\
43-60\end{array}$ & $\begin{array}{l}12.5(12.5) \\
0-25\end{array}$ & $\begin{array}{l}32.5(20.5) \\
12-53\end{array}$ & $\begin{array}{l}17(7) \\
10-24\end{array}$ \\
\hline Belted Kingfisher & 1 & 0.001 & $\begin{array}{l}5.5(-) \\
5.5-5.5\end{array}$ & $\begin{array}{l}94(-) \\
94-94\end{array}$ & $\begin{array}{l}2(-) \\
2-2\end{array}$ & $\begin{array}{l}0(-) \\
0-0\end{array}$ & $\begin{array}{l}4(-) \\
4-4\end{array}$ & $\begin{array}{l}58(-) \\
58-58\end{array}$ & $\begin{array}{l}20(-) \\
20-20\end{array}$ & $\begin{array}{l}17(-) \\
17-17\end{array}$ & $\begin{array}{l}18(-) \\
18-18\end{array}$ \\
\hline Blackpoll Warbler & 1 & 0.001 & $\begin{array}{l}1.2(-) \\
1.2-1.2\end{array}$ & $\begin{array}{l}55(-) \\
55-55\end{array}$ & $\begin{array}{l}5(-) \\
5-5\end{array}$ & $\begin{array}{l}25(-) \\
25-25\end{array}$ & $\begin{array}{l}15(-) \\
15-15\end{array}$ & $\begin{array}{l}61(-) \\
61-61\end{array}$ & $\begin{array}{l}26(-) \\
26-26\end{array}$ & $\begin{array}{l}10(-) \\
10-10\end{array}$ & $\begin{array}{l}31(-) \\
31-31\end{array}$ \\
\hline $\begin{array}{l}\text { Brewer's } \\
\text { Blackbird }\end{array}$ & 1 & 0.001 & $\begin{array}{l}4(-) \\
4-4\end{array}$ & $\begin{array}{l}0(-) \\
0-0\end{array}$ & $\begin{array}{l}10(-) \\
10-10\end{array}$ & $\begin{array}{l}80(-) \\
80-80\end{array}$ & $\begin{array}{l}10(-) \\
10-10\end{array}$ & $\begin{array}{l}74(-) \\
74-74\end{array}$ & $\begin{array}{l}21(-) \\
21-21\end{array}$ & $\begin{array}{l}3(-) \\
3-3\end{array}$ & $\begin{array}{l}21(-) \\
21-21\end{array}$ \\
\hline Canada Warbler & 1 & 0.001 & $\begin{array}{l}1.1(-) \\
1.1-1.1\end{array}$ & $\begin{array}{l}85(-) \\
85-85\end{array}$ & $\begin{array}{l}7(-) \\
7-7\end{array}$ & $\begin{array}{l}8(-) \\
8-8\end{array}$ & $\begin{array}{l}0(-) \\
0-0\end{array}$ & $\begin{array}{l}75(-) \\
75-75\end{array}$ & $\begin{array}{l}0(-) \\
0-0\end{array}$ & $\begin{array}{l}22(-) \\
22-22\end{array}$ & $\begin{array}{l}40(-) \\
40-40\end{array}$ \\
\hline Chipping Sparrow & 1 & 0.001 & $\begin{array}{c}60.73(-) \\
60.73-60.73\end{array}$ & $\begin{array}{l}40(-) \\
40-40\end{array}$ & $\begin{array}{l}20(-) \\
20-20\end{array}$ & $\begin{array}{l}30(-) \\
30-30\end{array}$ & $\begin{array}{l}10(-) \\
10-10\end{array}$ & $\begin{array}{l}43(-) \\
43-43\end{array}$ & $\begin{array}{l}0(-) \\
0-0\end{array}$ & $\begin{array}{l}53(-) \\
53-53\end{array}$ & $\begin{array}{l}10(-) \\
10-10\end{array}$ \\
\hline $\begin{array}{l}\text { Common } \\
\text { Goldeneye }\end{array}$ & 1 & 0.001 & $\begin{array}{l}32(-) \\
32-32\end{array}$ & $\begin{array}{l}50(-) \\
50-50\end{array}$ & $\begin{array}{l}40(-) \\
40-40\end{array}$ & $\begin{array}{l}10(-) \\
10-10\end{array}$ & $\begin{array}{l}0(-) \\
0-0\end{array}$ & $\begin{array}{l}44(-) \\
44-44\end{array}$ & $\begin{array}{l}40(-) \\
40-40\end{array}$ & $\begin{array}{l}11(-) \\
11-11\end{array}$ & $\begin{array}{l}16(-) \\
16-16\end{array}$ \\
\hline Common Tern & 1 & 0.001 & $\begin{array}{l}60(-) \\
60-60\end{array}$ & $\begin{array}{l}50(-) \\
50-50\end{array}$ & $\begin{array}{l}45(-) \\
45-45\end{array}$ & $\begin{array}{l}5(-) \\
5-5\end{array}$ & $\begin{array}{l}0(-) \\
0-0\end{array}$ & $\begin{array}{l}61(-) \\
61-61\end{array}$ & $\begin{array}{l}10(-) \\
10-10\end{array}$ & $\begin{array}{l}26(-) \\
26-26\end{array}$ & $\begin{array}{l}6(-) \\
6-6\end{array}$ \\
\hline $\begin{array}{l}\text { Eastern Wood } \\
\text { Pewee }\end{array}$ & 1 & 0.001 & $\begin{array}{l}1.1(-) \\
1.1-1.1\end{array}$ & $\begin{array}{l}85(-) \\
85-85\end{array}$ & $\begin{array}{l}7(-) \\
7-7\end{array}$ & $\begin{array}{l}8(-) \\
8-8\end{array}$ & $\begin{array}{l}0(-) \\
0-0\end{array}$ & $\begin{array}{l}75(-) \\
75-75\end{array}$ & $\begin{array}{l}0(-) \\
0-0\end{array}$ & $\begin{array}{l}22(-) \\
22-22\end{array}$ & $\begin{array}{l}40(-) \\
40-40\end{array}$ \\
\hline
\end{tabular}




\begin{tabular}{|c|c|c|c|c|c|c|c|c|c|c|c|}
\hline \multirow[b]{2}{*}{ Common name } & \multirow{2}{*}{$\begin{array}{l}\text { Number } \\
\text { of } \\
\text { wetlands } \\
\text { with } \\
\text { species } \\
\text { present }\end{array}$} & \multirow{2}{*}{$\begin{array}{l}\text { Proportion } \\
\text { of } \\
\text { wetlands } \\
\text { with } \\
\text { species } \\
\text { present }\end{array}$} & \multicolumn{5}{|c|}{ Wetland-level variables } & \multicolumn{4}{|c|}{ Landscape-level variables } \\
\hline & & & $\begin{array}{c}\text { Wetland size } \\
\text { (hectares) }\end{array}$ & $\begin{array}{l}\text { Percentage of } \\
\text { wetland in } \\
\text { open water }\end{array}$ & $\begin{array}{l}\text { Percentage of } \\
\text { the wetland in } \\
\text { emergent } \\
\text { vegetation }\end{array}$ & $\begin{array}{l}\text { Percentage of } \\
\text { the wetland in } \\
\text { wet meadow }\end{array}$ & $\begin{array}{l}\text { Percentage } \\
\text { of the } \\
\text { wetland in } \\
\text { shorelinel } \\
\text { mudflat }\end{array}$ & $\begin{array}{l}\text { Percentage of } \\
\text { grassland } \\
\text { area within } \\
800 \mathrm{~m}\end{array}$ & $\begin{array}{l}\text { Percentage of } \\
\text { agricultural } \\
\text { area within } \\
800 \mathrm{~m}\end{array}$ & $\begin{array}{c}\text { Percentage } \\
\text { of wetland } \\
\text { area within } \\
800 \mathrm{~m}\end{array}$ & $\begin{array}{c}\text { Number of } \\
\text { wetlands } \\
\text { within } 800 \mathrm{~m}\end{array}$ \\
\hline Ferruginous Hawk & 1 & 0.001 & $\begin{array}{l}4.86(-) \\
4.86-4.86\end{array}$ & $\begin{array}{l}60(-) \\
60-60\end{array}$ & $\begin{array}{l}10(-) \\
10-10\end{array}$ & $\begin{array}{l}20(-) \\
20-20\end{array}$ & $\begin{array}{l}10(-) \\
10-10\end{array}$ & $\begin{array}{l}88(-) \\
88-88\end{array}$ & $\begin{array}{l}0(-) \\
0-0\end{array}$ & $\begin{array}{l}7(-) \\
7-7\end{array}$ & $\begin{array}{l}12(-) \\
12-12\end{array}$ \\
\hline $\begin{array}{l}\text { Great Crested } \\
\text { Flycatcher }\end{array}$ & 1 & 0.001 & $\begin{array}{l}0.6(-) \\
0.6-0.6\end{array}$ & $\begin{array}{l}0(-) \\
0-0\end{array}$ & $\begin{array}{l}80(-) \\
80-80\end{array}$ & $\begin{array}{l}0(-) \\
0-0\end{array}$ & $\begin{array}{l}20(-) \\
20-20\end{array}$ & $\begin{array}{l}17(-) \\
17-17\end{array}$ & $\begin{array}{l}54(-) \\
54-54\end{array}$ & $\begin{array}{l}13(-) \\
13-13\end{array}$ & $\begin{array}{l}62(-) \\
62-62\end{array}$ \\
\hline $\begin{array}{l}\text { Great-tailed } \\
\text { Grackle }\end{array}$ & 1 & 0.001 & $\begin{array}{l}7(-) \\
7-7\end{array}$ & $\begin{array}{l}40(-) \\
40-40\end{array}$ & $\begin{array}{l}40(-) \\
40-40\end{array}$ & $\begin{array}{l}20(-) \\
20-20\end{array}$ & $\begin{array}{l}0(-) \\
0-0\end{array}$ & $\begin{array}{l}46(-) \\
46-46\end{array}$ & $\begin{array}{l}14(-) \\
14-14\end{array}$ & $\begin{array}{l}35(-) \\
35-35\end{array}$ & $\begin{array}{l}28(-) \\
28-28\end{array}$ \\
\hline Lark Sparrow & 1 & 0.001 & $\begin{array}{l}0.4(-) \\
0.4-0.4\end{array}$ & $\begin{array}{l}55(-) \\
55-55\end{array}$ & $\begin{array}{l}40(-) \\
40-40\end{array}$ & $\begin{array}{l}0(-) \\
0-0\end{array}$ & $\begin{array}{l}5(-) \\
5-5\end{array}$ & $\begin{array}{l}29(-) \\
29-29\end{array}$ & $\begin{array}{l}65(-) \\
65-65\end{array}$ & $\begin{array}{l}0(-) \\
0-0\end{array}$ & $\begin{array}{l}2(-) \\
2-2\end{array}$ \\
\hline Purple Martin & 1 & 0.001 & $\begin{array}{l}4(-) \\
4-4\end{array}$ & $\begin{array}{l}10(-) \\
10-10\end{array}$ & $\begin{array}{l}0(-) \\
0-0\end{array}$ & $\begin{array}{l}90(-) \\
90-90\end{array}$ & $\begin{array}{l}0(-) \\
0-0\end{array}$ & $\begin{array}{l}43(-) \\
43-43\end{array}$ & $\begin{array}{l}30(-) \\
30-30\end{array}$ & $\begin{array}{l}24(-) \\
24-24\end{array}$ & $\begin{array}{l}32(-) \\
32-32\end{array}$ \\
\hline Rock Pigeon & 1 & 0.001 & $\begin{array}{l}0.2(-) \\
0.2-0.2\end{array}$ & $\begin{array}{l}10(-) \\
10-10\end{array}$ & $\begin{array}{l}80(-) \\
80-80\end{array}$ & $\begin{array}{l}10(-) \\
10-10\end{array}$ & $\begin{array}{l}0(-) \\
0-0\end{array}$ & $\begin{array}{l}16(-) \\
16-16\end{array}$ & $\begin{array}{l}75(-) \\
75-75\end{array}$ & $\begin{array}{l}5(-) \\
5-5\end{array}$ & $\begin{array}{l}17(-) \\
17-17\end{array}$ \\
\hline $\begin{array}{l}\text { Semipalmated } \\
\text { Sandpiper }\end{array}$ & 1 & 0.001 & $\begin{array}{l}4(-) \\
4-4\end{array}$ & $\begin{array}{l}10(-) \\
10-10\end{array}$ & $\begin{array}{l}0(-) \\
0-0\end{array}$ & $\begin{array}{l}90(-) \\
90-90\end{array}$ & $\begin{array}{l}0(-) \\
0-0\end{array}$ & $\begin{array}{l}43(-) \\
43-43\end{array}$ & $\begin{array}{l}30(-) \\
30-30\end{array}$ & $\begin{array}{l}24(-) \\
24-24\end{array}$ & $\begin{array}{l}32(-) \\
32-32\end{array}$ \\
\hline $\begin{array}{l}\text { Sharp-tailed } \\
\text { Grouse }\end{array}$ & 1 & 0.001 & $\begin{array}{l}0.4(-) \\
0.4-0.4\end{array}$ & $\begin{array}{l}50(-) \\
50-50\end{array}$ & $\begin{array}{l}10(-) \\
10-10\end{array}$ & $\begin{array}{l}30(-) \\
30-30\end{array}$ & $\begin{array}{l}10(-) \\
10-10\end{array}$ & $\begin{array}{l}81(-) \\
81-81\end{array}$ & $\begin{array}{l}0(-) \\
0-0\end{array}$ & $\begin{array}{l}16(-) \\
16-16\end{array}$ & $\begin{array}{l}13(-) \\
13-13\end{array}$ \\
\hline Snow Goose & 1 & 0.001 & $\begin{array}{c}44.53(-) \\
44.53-44.53\end{array}$ & $\begin{array}{l}60(-) \\
60-60\end{array}$ & $\begin{array}{l}10(-) \\
10-10\end{array}$ & $\begin{array}{l}25(-) \\
25-25\end{array}$ & $\begin{array}{l}5(-) \\
5-5\end{array}$ & $\begin{array}{l}14(-) \\
14-14\end{array}$ & $\begin{array}{l}0(-) \\
0-0\end{array}$ & $\begin{array}{l}82(-) \\
82-82\end{array}$ & $\begin{array}{l}1(-) \\
1-1\end{array}$ \\
\hline Snowy Egret & 1 & 0.001 & $\begin{array}{l}5.5(-) \\
5.5-5.5\end{array}$ & $\begin{array}{l}50(-) \\
50-50\end{array}$ & $\begin{array}{l}50(-) \\
50-50\end{array}$ & $\begin{array}{l}0(-) \\
0-0\end{array}$ & $\begin{array}{l}0(-) \\
0-0\end{array}$ & $\begin{array}{l}82(-) \\
82-82\end{array}$ & $\begin{array}{l}0(-) \\
0-0\end{array}$ & $\begin{array}{l}15(-) \\
15-15\end{array}$ & $\begin{array}{l}31(-) \\
31-31\end{array}$ \\
\hline Tennessee Warbler & 1 & 0.001 & $\begin{array}{c}10.93(-) \\
10.93-10.93\end{array}$ & $\begin{array}{l}75(-) \\
75-75\end{array}$ & $\begin{array}{l}0(-) \\
0-0\end{array}$ & $\begin{array}{l}0(-) \\
0-0\end{array}$ & $\begin{array}{l}25(-) \\
25-25\end{array}$ & $\begin{array}{l}41(-) \\
41-41\end{array}$ & $\begin{array}{l}26(-) \\
26-26\end{array}$ & $\begin{array}{l}26(-) \\
26-26\end{array}$ & $\begin{array}{l}11(-) \\
11-11\end{array}$ \\
\hline
\end{tabular}




\begin{tabular}{|c|c|c|c|c|c|c|c|c|c|c|c|}
\hline \multirow[b]{2}{*}{ Common name } & \multirow{2}{*}{$\begin{array}{l}\text { Number } \\
\text { of } \\
\text { wetlands } \\
\text { with } \\
\text { species } \\
\text { present }\end{array}$} & \multirow{2}{*}{$\begin{array}{c}\text { Proportion } \\
\text { of } \\
\text { wetlands } \\
\text { with } \\
\text { species } \\
\text { present }\end{array}$} & \multicolumn{5}{|c|}{ Wetland-level variables } & \multicolumn{4}{|c|}{ Landscape-level variables } \\
\hline & & & $\begin{array}{c}\text { Wetland size } \\
\text { (hectares) }\end{array}$ & $\begin{array}{l}\text { Percentage of } \\
\text { wetland in } \\
\text { open water }\end{array}$ & $\begin{array}{c}\text { Percentage of } \\
\text { the wetland in } \\
\text { emergent } \\
\text { vegetation }\end{array}$ & $\begin{array}{l}\text { Percentage of } \\
\text { the wetland in } \\
\text { wet meadow }\end{array}$ & $\begin{array}{l}\text { Percentage } \\
\text { of the } \\
\text { wetland in } \\
\text { shorelinel } \\
\text { mudflat }\end{array}$ & $\begin{array}{l}\text { Percentage of } \\
\text { grassland } \\
\text { area within } \\
800 \mathrm{~m}\end{array}$ & $\begin{array}{l}\text { Percentage of } \\
\text { agricultural } \\
\text { area within } \\
800 \mathrm{~m}\end{array}$ & $\begin{array}{c}\text { Percentage } \\
\text { of wetland } \\
\text { area within } \\
800 \mathrm{~m}\end{array}$ & $\begin{array}{c}\text { Number of } \\
\text { wetlands } \\
\text { within } 800 \mathrm{~m}\end{array}$ \\
\hline Veery & 1 & 0.001 & $\begin{array}{l}1.2(-) \\
1.2-1.2\end{array}$ & $\begin{array}{l}20(-) \\
20-20\end{array}$ & $\begin{array}{l}75(-) \\
75-75\end{array}$ & $\begin{array}{l}5(-) \\
5-5\end{array}$ & $\begin{array}{l}0(-) \\
0-0\end{array}$ & $\begin{array}{l}63(-) \\
63-63\end{array}$ & $\begin{array}{l}29(-) \\
29-29\end{array}$ & $\begin{array}{l}2(-) \\
2-2\end{array}$ & $\begin{array}{l}15(-) \\
15-15\end{array}$ \\
\hline White Ibis & 1 & 0.001 & $\begin{array}{l}5.47(-) \\
5.47-5.47\end{array}$ & $\begin{array}{l}25(-) \\
25-25\end{array}$ & $\begin{array}{l}65(-) \\
65-65\end{array}$ & $\begin{array}{l}8(-) \\
8-8\end{array}$ & $\begin{array}{l}2(-) \\
2-2\end{array}$ & $\begin{array}{l}77(-) \\
77-77\end{array}$ & $\begin{array}{l}3(-) \\
3-3\end{array}$ & $\begin{array}{l}14(-) \\
14-14\end{array}$ & $\begin{array}{l}11(-) \\
11-11\end{array}$ \\
\hline Wilson's Warbler & 1 & 0.001 & $\begin{array}{l}1.1(-) \\
1.1-1.1\end{array}$ & $\begin{array}{l}85(-) \\
85-85\end{array}$ & $\begin{array}{l}7(-) \\
7-7\end{array}$ & $\begin{array}{l}8(-) \\
8-8\end{array}$ & $\begin{array}{l}0(-) \\
0-0\end{array}$ & $\begin{array}{l}75(-) \\
75-75\end{array}$ & $\begin{array}{l}0(-) \\
0-0\end{array}$ & $\begin{array}{l}22(-) \\
22-22\end{array}$ & $\begin{array}{l}40(-) \\
40-40\end{array}$ \\
\hline Wood Thrush & 1 & 0.001 & $\begin{array}{l}1.2(-) \\
1.2-1.2\end{array}$ & $\begin{array}{l}55(-) \\
55-55\end{array}$ & $\begin{array}{l}5(-) \\
5-5\end{array}$ & $\begin{array}{l}25(-) \\
25-25\end{array}$ & $\begin{array}{l}15(-) \\
15-15\end{array}$ & $\begin{array}{l}61(-) \\
61-61\end{array}$ & $\begin{array}{l}26(-) \\
26-26\end{array}$ & $\begin{array}{l}10(-) \\
10-10\end{array}$ & $\begin{array}{l}31(-) \\
31-31\end{array}$ \\
\hline
\end{tabular}


Publishing support provided by:

Rolla Publishing Service Center

For more information concerning this publication, contact:

Director, USGS, Northern Prairie Wildlife Research Center

8711 37th Street Southeast

Jamestown, North Dakota 58401

(701) 253-5500

Or visit the Northern Prairie Wildlife Research Center website at: https://www.npwrc.usgs.gov/ 